Ronaldo Andrade dos Santos

Saberes Socioambientais associados à Educação Escolar Quilombola na Comunidade do Mumbuca, Jalapão/TO

Socioenvironmental knowledge associated with Quilombola School Education in Mumbuca Community, Jalapão/TO

São Paulo 
Ronaldo Andrade dos Santos

\section{Saberes Socioambientais associados à Educação Escolar Quilombola na Comunidade do Mumbuca, Jalapão/TO}

Socioenvironmental knowledge associated with Quilombola School Education in Mumbuca Community, Jalapão/TO

Dissertação apresentada ao Programa de Pósgraduação em Ciências Biológicas - Botânica (Instituto de Biociências da Universidade de São Paulo) para obtenção do título de Mestre em Ciências Biológicas Botânica.

Área de Concentração: Ensino de Botânica

Orientador: Prof. Dr. Paulo Takeo Sano

São Paulo 
Ficha catalográfica elaborada pelo Serviço de Biblioteca do Instituto de Biociências da USP. com os dados fornecidos pelo autor no formulário: http://wwww.ib.usp.br/biblioteca/ficha-catalografica/ficha.php

doe Santoa, Ronaldo Andrade

Saberen' Socioambientain anmociadon a Bducação Bucolar Quilombola na Comunidade do Numbuca, Jalapāo/To / Ronaldo Andrade doa Santon; orientador Paulo Takeo Sano. -- Säo Paulo, 2019.

$135 \mathrm{f} .+$ anexo

Dismertaç̄o (Meatrado) - Instituto de Biociencian da Univeraidade de Så Paulo, Departamento de Botinica.

1. Educaç̄̄o Ambiental. 2. Educaç̄̄o Quilombola. 3. Saber Ambiental. 4. Dislogo de Saberea. 5. Jalapj̄o. I. Sano, Paulo Takeo, orient. II. Titulo.

B1bliotecár1a responsável pela estrutura da catalogaçăo da publicaçåo: El1sabete da Cruz Neves - CRB - B/622B 
Nome: SANTOS, Ronaldo Andrade.

Título: Saberes Socioambientais associados à Educação Escolar Quilombola na Comunidade do Mumbuca, Jalapão / TO.

Dissertação apresentada ao Programa de Pós-graduação em Ciências Biológicas - Botânica (Instituto de Biociências da Universidade de São Paulo) para obtenção do título de Mestre em Ciências Biológicas - Botânica.

Aprovado em:

\section{Banca Examinadora}

Prof. Dr.

Instituição:

Julgamento:

Profa. Dra.

Instituição:

Julgamento:

Prof. Dr.

Instituição:

Julgamento: 
Pé quente, cabeça fria À minha mãe, Ana Lúcia, por simplesmente sê-la Saia despreocupada, você pode conquistar o mundo dessa vez. 


\section{AGRADECIMENTOS}

Agradeço a todos os moradores da comunidade do Mumbuca, em especial, a família de Daldivina Silva e Arnon Tavares, que me hospedou durante a maioria das viagens de campo; assim como a Marijane Silva, pela assistência durante as viagens e facilitação da comunicação com a comunidade quando necessário.

Aos professores participantes da pesquisa, que aceitaram o desafio de refletir sobre suas próprias práticas docentes.

Ao Paulo Sano, caminhante, pela confiança na orientação desta pesquisa e pela abertura dos caminhos jalapoeiros a mim.

A Rebeca Viana, pelas revisões iniciais deste projeto e pelos diálogos inspiradores, mesmo de forma esporádica.

À Coordenadoria de Aperfeiçoamento de Pessoal de Nível Superior (Capes), pela concessão da bolsa de mestrado; e ao Instituto de Biociências da USP (IB) pelo apoio ao projeto de pesquisa.

Aos amigos feitos pelo caminho, em Mateiros: Rejane Ferreira, Carlos Ferreira, Cassiana Moreira, Salomé Sarachu e Thomas Tanaka.

Aos novos amigos em São Paulo: Murilo Luz, Neni Benaventi, Luma Prado, Vitor Lima, Tatiana Tavares, André Gomes, Geferson Santana, Saulo Almeida, Danyllo Ferreira, Magno Henrique e Matheus Andrade.

Aos saudosos amigos, em/de Belém: Lorena Nóbrega, Tanya Maria, Chiara Campos, André Andrade, Hannaka Nunes e Pauline Protásio.

Aos amigos educadores espalhados pelo Brasil: Ana Fournier, Ana Marcela, Chris Rothier, Daniel Fagundes, Fernanda Vargas, Alana Mendonça, Adriana Cardoso, Rafael Carvalho, Claudia Ribeiro, Pablo Matos, Gabriel Diniz, Robevânia das Virgens, Stella Carleto e lara Ramos, façamos amor e revolução.

A minha família, em especial à Valéria Andrade, por ter sido desde sempre a portadora da palavra cuidado.

Ao Andi El Canijo e à Trini Fumero, maestros, siéntate conmigo al fuego.

Aos professores e estudantes de disciplinas cursadas durante o mestrado.

Abraço e agradeço. 
"'Para que a escrita seja legível,

é preciso dispor os instrumentos, exercitar a mão, conhecer todos os caracteres. Mas para começar a dizer alguma coisa que valha a pena, é preciso conhecer todos os sentidos de todos os caracteres, e ter experimentado em si próprio todos esses sentidos, e ter observado no mundo e no transmundo todos os resultados dessas experiências." (Cecília Meireles, maio de 1963) $^{1}$

\footnotetext{
${ }^{1}$ Meireles, Cecília. Para que esta escrita seja legível. IN: Poesia Completa. Ed. Nova Aguilar, Rio de Janeiro, 1993.
} 


\section{SUMÁRIO}

INTERFACES ENTRE EDUCAÇÃO AMBIENTAL E EDUCAÇÃO QUILOMBOLA ...11

1. Educação Ambiental em uma perspectiva histórico-crítica ..................................... 11

1.1. Aspectos conceituais e legais da Educação Ambiental ............................11

1.2. Aspectos históricos e filosóficos da Educação Ambiental ...........................15

1.3. Aspectos freireanos da Educação Ambiental........................................18

2. Educação Popular Comunitária/Quilombola em uma perspectiva da Educação Social

2.1. Educação Quilombola e sua relação com o desenvolvimento da Pedagogia Social

2.2. Educação Quilombola e sua relação com a temática socioambiental.........25

3. Contexto da Comunidade e dos Sujeitos Participantes ........................................ 29

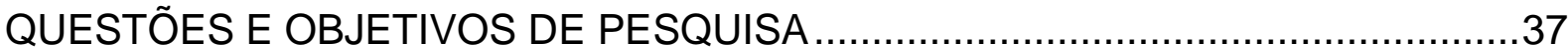

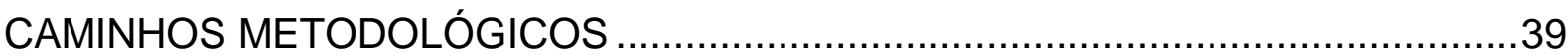

1. Pesquisa qualitativa e participante …………………............................................. 39

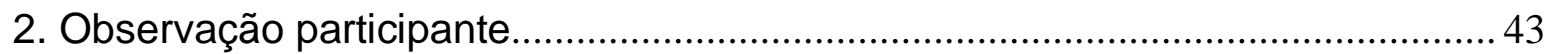

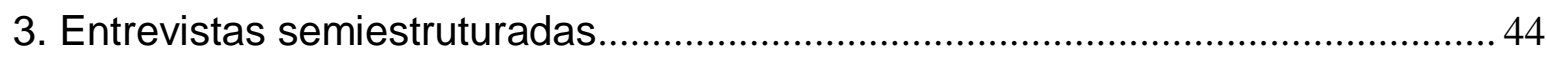

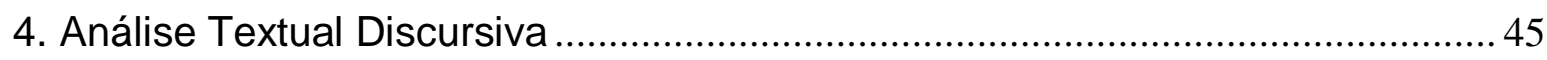

4.1. Estilos e Coletivos de Pensamento ......................................................

4.2. Diferentes Correntes em Educação Ambiental..............................................48

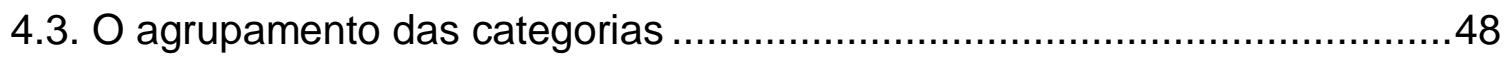

O NOVO EMERGENTE ARTICULADO ÀS CATEGORIAS DE ANÁLISE ................52

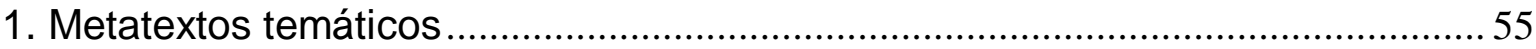

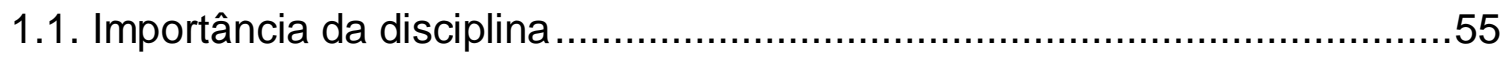

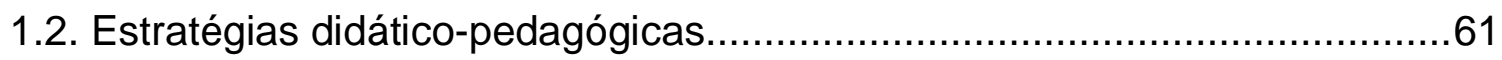

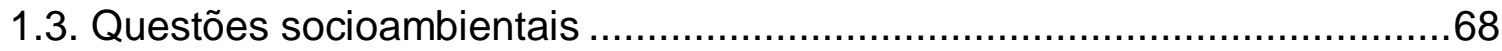

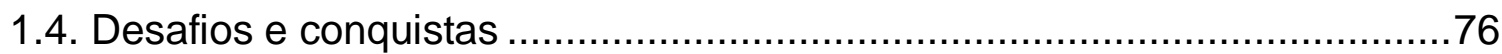

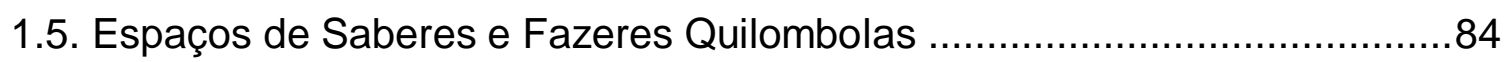

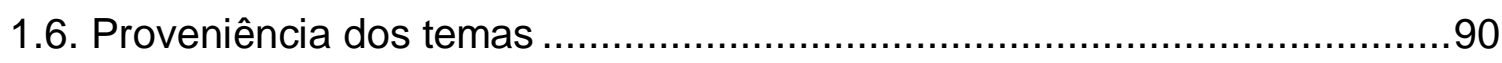

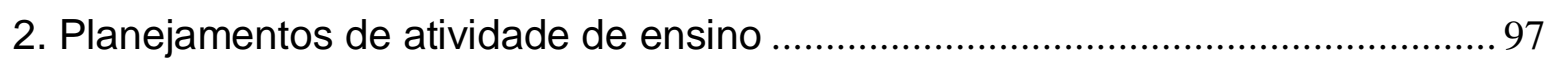

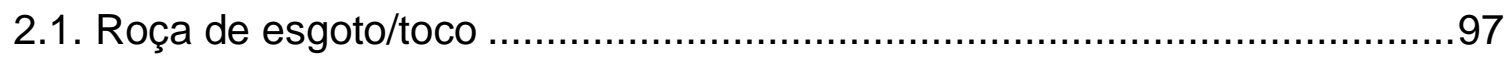

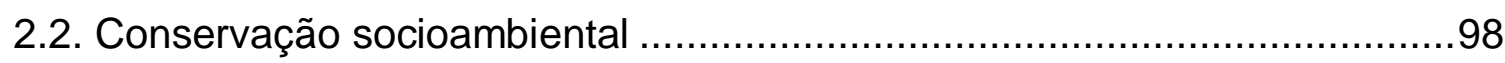




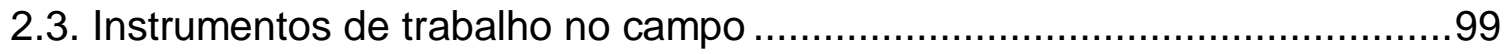

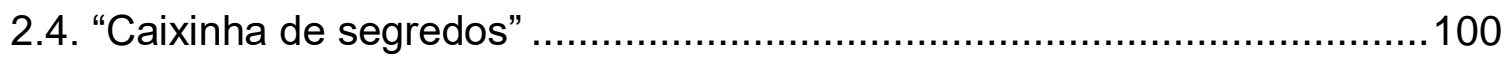

2.5. "Dunas" - ponto turístico da região ………..........................................100

2.6. Alimentação quilombola e os frutos do Cerrado.....................................101

3. O Coletivo de Pensamento entre Correntes de Educação Ambiental ................ 102

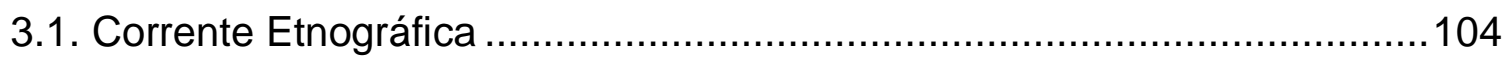

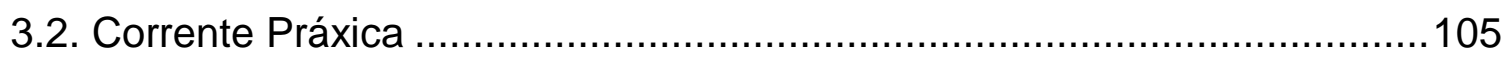

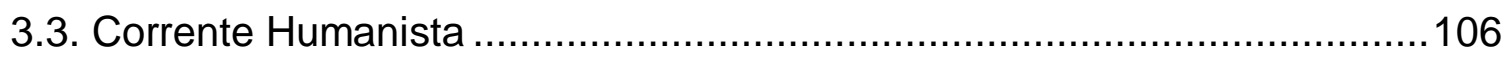

3.4. Corrente Conservacionista/Recursista ...............................................107

4. O saber ambiental emergente da práxis pedagógica histórico-crítica................ 107

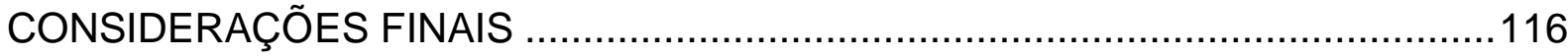

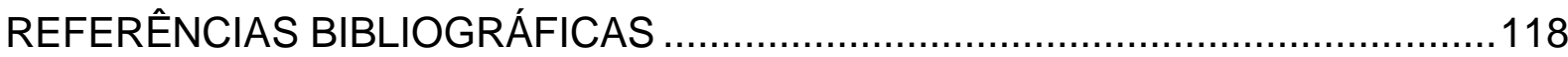

RESUMO

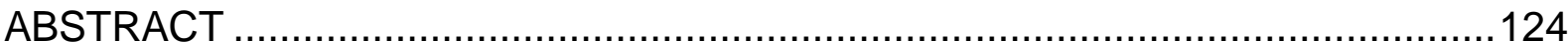

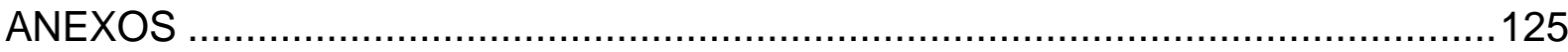

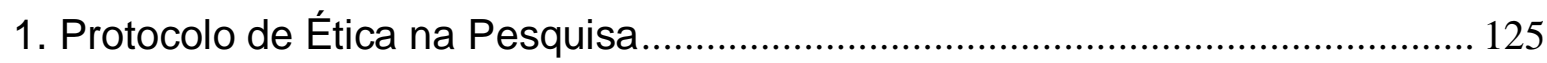

2. Termo de Consentimento Livre e Esclarecido .................................................. 127

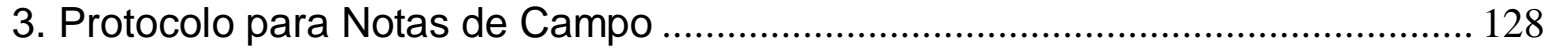

4. Estrutura básica do componente curricular ........................................................ 129

\section{Lista de Figuras}

Figura 1 - Localização do Parque Estadual do Jalapão ……….......................... 30

Figura 2 - Território Quilombola Mumbuca ……………………………...... 31

Figura 3 - Comunidade do Mumbuca …………......................................... 33

Figura 4 - Escola Estadual Severino Ribeiro Matos ........................................ 34

Figura 5 - Sistematização da produção de metatextos …………...................... 49

Figura 6 - Sistematização da produção de metatextos .................................... 50

\section{Lista de Tabelas}

Tabela 1 - Cronograma de viagens de campo ……........................................ 42

Tabela 2 - Importância da disciplina .......................................................... 59 


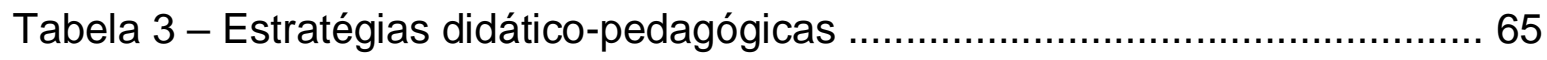

Tabela 4 - Questões Socioambientais ........................................................... 72

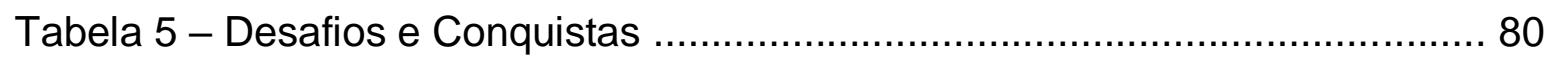

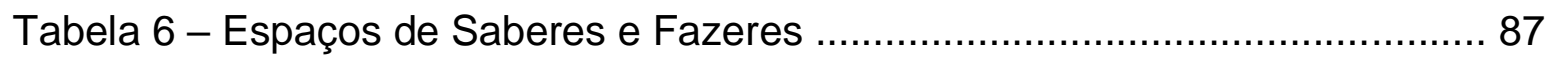

Tabela 7 - Proveniência dos temas ............................................................ 94 


\section{INTERFACES ENTRE EDUCAÇÃO AMBIENTAL E EDUCAÇÃO QUILOMBOLA}

\section{Educação Ambiental em uma perspectiva histórico-crítica}

A Educação Ambiental (EA) deve ser discutida como um Campo Social em constante mudança histórica e paradigmática. Aqui, em um primeiro momento, apresentaremos os aspectos conceituais importantes desse campo, com suas dimensões legais e sua articulação com conceitos como interdisciplinaridade e complexidade, permitindo ainda expor as três macrotendências do campo social: conservadora, pragmática e crítica.

Em uma segunda seção, a EA surge sob a ótica de seus aspectos históricos e filosóficos, através do conceito de armadilha paradigmática e da evolução históricoepistemológica do campo social no que tange à caracterização dos diferentes estilos de pensamento identificados em trabalhos na área, estilo de pensamento ecológico e estilo de pensamento crítico-transformador.

Ao final, procuramos associar a macrotendência crítica e o estilo de pensamento crítico-transformador aos princípios educacionais encontrados na Pedagogia Freireana, permitindo visualizar um elo com as teorizações sobre Educação Popular, Comunitária e Quilombola que serão discutidas no capítulo seguinte desta dissertação.

\subsection{Aspectos conceituais e legais da Educação Ambiental}

Entende-se por EA,

"os processos por meio dos quais o indivíduo e a coletividade constroem valores sociais, conhecimentos, habilidades, atitudes e competências voltadas para a conservação do meio ambiente, bem de uso comum do povo, essencial à sadia qualidade de vida e sua sustentabilidade" (Brasil, 1999)

É, portanto, mais do que uma "forma" de educação, pois diz respeito a uma dimensão fundamental da educação que se articula com o desenvolvimento pessoal e social dos indivíduos através da interação com o meio em que vivem, propiciando a indução de dinâmicas sociais por uma abordagem colaborativa e crítica das questões socioambientais apresentadas em uma localidade (Sauvé, 2005). Em seu sentido de coletividade, educa para a cidadania, pois contribui na formação responsável dos 
sujeitos pelo mundo que habitam (Sorrentino et al., 2005), apresentando-se, então, como uma ação política (Cascino, 1999).

Traduz-se, portanto, como um instrumento importante para a conservação da natureza, na medida em que permite o diálogo entre conhecimento científico e conhecimento tradicional por meios transdisciplinares (Andreoli, 2009). Entende-se, dessa forma, que a relação sociedade-natureza não se configura somente como um estudo das Ciências Biológicas, mas articula todos os ramos das ciências, incluindo as Ciências Sociais, sendo as inter-relações justapostas historicamente sobre essas áreas importantes para compreender as perspectivas epistemológicas diversas presentes no campo (Leff, 2011).

Layrargues e Lima (2011), utilizando-se da noção de Campo Social, definida por Bourdieu (2001, 2004), considera que o universo da Educação Ambiental pode ser entendido como um subcampo oriundo do campo ambientalista, ou como um campo relativamente independente de atividade e de saber, que retira do ambientalista os elementos básicos de sua identidade e se articula com o campo educacional em múltiplas vertentes, como seus propósitos, cultura, saberes e práticas.

Tal noção de Campo Social permite compreender que a Educação Ambiental é composta por diversos atores, grupos e instituições sociais que compartilham valores comuns. No entanto, esses atores diferenciam-se em inúmeros aspectos, tais como suas concepções sobre meio ambiente ou sobre suas propostas políticas, pedagógicas e epistemológicas na abordagem da questão ambiental (Layrargues, 2012). O processo de disputa pela hegemonia no campo social, por estes atores, a fim de orientar as interpretações da realidade de acordo com seus interesses, é identificado em Layrargues e Lima (2011) e Layrargues (2012) em três grandes macrotendências político-pedagógicas em Educação Ambiental, conhecidas como tendências conservacionista, pragmática e crítica.

Em resumo, a macrotendência conservacionista associa-se, sobretudo, com as correntes conservacionista, naturalista, da Alfabetização Ecológica, entre outras, vinculando a Educação Ambiental à "pauta verde", como ecoturismo, trilhas interpretativas, biodiversidade, Unidades de Conservação e dinâmicas agroecológicas. Por sua vez, a macrotendência pragmática inclui as correntes da Educação para o Desenvolvimento Sustentável e para o Consumo Sustentável, 
associando-se à "pauta marrom" por ser urbano-industrial, ligada à temática do lixo, coleta seletiva e reciclagem de resíduos. Enquanto isso, a macrotendência crítica abrange as correntes da Educação Ambiental Popular e Emancipatória, assumindo um forte viés sociológico que introduz conceitos-chave, como Política, Ação Coletiva, Cidadania, Democracia, Emancipação e Transformação Social (Layrargues, 2012).

Como herdeira direta do movimento ecológico/ambientalista que formulou a compreensão da crise como uma questão de interesse público, a EA representa a preocupação da sociedade em geral com a qualidade da existência das gerações atuais e futuras e figura entre as alternativas de construção de uma nova forma de se relacionar com o meio ambiente (Carvalho, 2004).

A Conferência de Estocolmo sobre Meio Ambiente Humano, em 1972, e a Conferência Intergovernamental sobre Educação Ambiental, em Tbilisi no ano de 1977, impulsionaram o movimento mundial para a formação de uma consciência sobre o valor da natureza, orientando os processos de produção do conhecimento pelos princípios da interdisciplinaridade e da complexidade (Leff, 2003). No Brasil, as principais políticas públicas para Educação Ambiental, desde os anos 1980, no auge do debate ecológico, constituem propostas pedagógicas concebidas como uma nova orientação em educação a partir dessa consciência da crise ambiental (Carvalho, 2004).

Apesar de não ser a intenção deste trabalho analisar as políticas públicas que regulamentam o campo, é importante registrar que há um conjunto delas que compõem um aparato legal e histórico. Carvalho (2004) as apresenta cronologicamente:

1988, Inclusão da EA como direito de todos e dever do Estado no capítulo de meio ambiente da Constituição;

1992, Criação dos Núcleos de Educação Ambiental pelo Instituto Brasileiro do Meio Ambiente e dos Recursos Naturais Renováveis (Ibama) e dos Centros de Educação Ambiental pelo Ministério da Educação (MEC);

1994, Criação do Programa Nacional de Educação Ambiental (Pronea) pelo MEC e pelo Ministério do Meio Ambiente (MMA);

1997, Elaboração dos Parâmetros Curriculares definidos pela Secretaria de Ensino Fundamental do MEC, em que "meio ambiente" é incluído como um dos temas transversais;

1999, Aprovação da Política Nacional da EA pela Lei 9.795;

2001, Implementação do Programa Parâmetros em Ação: meio ambiente na escola, pelo MEC;

2002, Regulamentação da Política Nacional de EA (Lei 9.975) pelo Decreto 4.281 ; 
2003, Criação do Órgão Gestor da Política Nacional de EA reunindo MEC e MMA (Carvalho, 2004, p. 52-3).

Nos documentos educacionais oficiais brasileiros, como a Lei de Diretrizes e Bases da Educação Nacional (LDBEN) (Brasil, 1996), os Parâmetros Curriculares Nacionais (PCN) (Brasil, 1997; 1998; 2000) e o Plano Nacional de Educação (PNE) (Brasil, 2001) é notória a ênfase ao desenvolvimento de uma educação escolar problematizadora, contextualizada e interdisciplinar, preocupada com a formação de sujeitos críticos e transformadores (Torres et al, 2014).

A elaboração do Tratado de Educação Ambiental para Sociedades Sustentáveis e Responsabilidade Global, durante a Conferência das Nações Unidas sobre Meio Ambiente e Desenvolvimento (Eco-92), estabeleceu uma carta de princípios importantes sobre EA. Cascino (1999) elenca alguns que apontam para certa mudança paradigmática e epistemológica da área, tais como: (a) A educação ambiental não é neutra, mas ideológica; é um ato político; (b) $A$ educação ambiental deve envolver uma perspectiva holística, enfocando a relação entre o ser humano, a natureza e o universo de forma interdisciplinar; (c) A educação ambiental deve tratar das questões globais críticas, suas causas e inter-relações em uma perspectiva sistêmica, em seu contexto social e histórico e (d) A educação ambiental deve promover a cooperação e o diálogo entre indivíduos e instituições, com a finalidade de criar novos modos de vida baseados em atender às necessidades básicas de todos, sem distinções étnicas, físicas, de gênero, idade, religião ou classe.

No entanto, Cascino (1999) reitera que as intenções expressas nesses tipos de documentos são distantes do que é desenvolvido na prática, já que a perda da dimensão complexa é recorrente em trabalhos publicados na área, pois, a despeito de o ideário metodológico interdisciplinar encaminhar a ação pedagógica para a experimentação e investigação, a revisitação de práticas educacionais tradicionais ainda ocorre na prática, sem a incorporação do ambíguo, do contraditório e da investigação perene. Desse modo, alguns aspectos históricos devem ser considerados pra entender as diferentes fases epistemológicas pelas quais passou a EA e os motivos da persistência de práticas educativas de cunho tradicional. 


\subsection{Aspectos históricos e filosóficos da Educação Ambiental}

Guimarães (2006), partindo dos trabalhos de Morin $(1997,2000)$ e Capra (1997), argumenta sobre um aspecto importante da evolução epistemológica da Educação Ambiental, passando pelo conceito de armadilha paradigmática. Das reflexões presentes nestes autores, ressalta-se a força que os paradigmas possuem na condução das práticas sociais e na consolidação de representações sociais, assim como nas ações individuais, perpetrando uma visão de mundo confirmadora de uma racionalidade dominante e possibilitando a retroalimentação dos mesmos paradigmas já estabelecidos.

Historicamente, o debate ecológico/ambiental primeiramente concebe uma prática de conscientização que chama atenção para os limites, a distribuição e o acesso aos recursos ambientais apropriados socialmente por determinados grupos e a aceitação da questão ambiental como uma problemática passível de afetar diretamente o destino da humanidade, mobilizando governos e sociedade civil em iniciativas de grupos, de associações e de movimentos ecológicos. Posteriormente, a EA veio se transformando em uma proposta educativa propriamente dita, dialogando com esse campo em suas tradições, teorias e saberes e se apresentando de forma transversal e interdisciplinar nos diferentes níveis e ambientes de ensino (Carvalho, 2004).

Sinaliza-se o fato de estar ocorrendo a mudança de uma representação social naturalista para a representação social globalizante de meio ambiente (Torres et al., 2014). Um breve histórico sobre a relação epistemológica estabelecida no pensamento ocidental, sobre meio ambiente, é necessário para compreender a construção dos modelos atuais de EA em perspectivas integradas e interdisciplinares. A começar pela ruptura dos modelos que situavam a compreensão do real em instâncias externas ao mundo humano, o século XVIII alcançou a quebra do paradigma do mito e da religião como representação humana do real e o alterou para uma posição mais centralizada no sujeito e na razão, inaugurando uma fase de racionalidade na modernidade, comumente chamada de "revolução científica" (Carvalho, 2004). 
Nesse momento, a partir de uma lógica binária, tal perspectiva cientificista permitiu o estabelecimento de dualidades que incluem a criação do par ser humano $x$ natureza (Guimarães, 2006). Essa separação entre o sujeito cognoscitivo, o ser humano, e o objeto de conhecimento, a natureza, característica deste paradigma epistemológico moderno, foi um dos frutos dessa nova forma de pensar a natureza que já não era mais vista em sua totalidade, mas passou a ser descrita e matematizada de forma minuciosa como objeto que foi concebida (Carvalho, 2004).

Esse processo de didatização e disciplinarização objetiva culminou em uma redução gradual de uma complexidade natural da racionalidade; aprendemos portanto a pensar o mundo binariamente, dualmente separados através dos pares natureza/cultura, corpo/mente, sujeito/objeto, razão/emoção, etc. (Carvalho, 2004). No entanto, esse modo de observação, que simultaneamente aprofunda a compreensão de partes isoladas, reduz a realidade e ofusca a complementaridade entre as partes, impedindo uma abordagem integrativa que permita uma compreensão mais ampla ou complexa da realidade, sob um enfoque dialógico (Guimarães, 2006).

A redução gradual da complexidade resultou no que Delizoicov e Delizoicov (2014) apontam como a construção de um Estilo de Pensamento Ecológico, cuja concepção de meio ambiente reduz-se ao estudo da natureza, em especial da flora e fauna; ou ao estudo do espaço que cerca os povos humanos ou ainda a própria natureza e seus diversos elementos, sinonimizando meio ambiente e natureza em uma representação social naturalista.

Contudo, as questões ambientais e os outros problemas teóricos e práticos da contemporaneidade tendem a não se encaixar mais nessa formulação epistemológica e tal paradigma começa a entrar em crise pelo fato de ter excluído a diversidade das formas de saber, em nome de uma possível universalidade metodológica reducionista dos fenômenos amplos e complexos a leis gerais diminuidoras de horizontes epistemológicos (Carvalho, 2004). Busca-se hoje uma racionalidade ambiental que se contraponha ao reducionismo explicativo de uma verdade absoluta (Leff, 2011).

Desse modo, a fim de superar a armadilha paradigmática quando os educadores, seres sociais que são, encontram-se atrelados a uma visão fragmentária e reduzida da realidade, manifestam uma compreensão limitada da problemática ambiental por experimentarem, em seu cotidiano, a reprodução de uma realidade 
estabelecida por uma racionalidade hegemônica (Guimarães, 2006), é imperativo que a crítica ao paradigma moderno rompa essas dicotomias conceituais e estabeleça a possibilidade de conjugação das muitas formas de pensar e ler o mundo, entrelaçando diferentes perspectivas epistemológicas (Carvalho, 2004).

Como consequência desse renovo epistemológico, desenvolve-se o chamado Estilo de Pensamento Crítico-Transformador, cuja compreensão de meio ambiente assume um lugar inter-relacional dinâmico entre os elementos naturais e sociais, implicando processos de transformação cultural, histórica, social e tecnológica da natureza e da humanidade (Delizoicov e Delizoicov, 2014). Não é demais ressaltar que os diferentes estilos de pensamento são categorias epistemológicas oriundas de um momento histórico e de um referencial teórico e metodológico compartilhado (Fleck, 1986), portanto, são concepções construídas por determinados grupos sociais (Delizoicov e Delizoicov, 2014).

Tal Estilo de Pensamento Crítico-Transformador (Delizoicov e Delizoicov, 2014) sintoniza-se com a macrotendência Crítica de EA (Layrargues, 2012), nesse contexto compreendida como uma filosofia da educação que reorienta epistemologicamente a ação humana, alterando aspectos culturais e sociais diante de situações concretas da vida dos sujeitos (Torres et al, 2014). Diferentemente da visão ingênua e conservadora, presa à armadilha paradigmática (Guimarães, 2006), as novas abordagens teórico-metodológicas abrem o caminho para uma nova perspectiva em que o sujeito formado torna-se consciente das inter-relações existentes entre sociedade, cultura e natureza, já que ele se reconhece ativo nos processos de transformação sociais, históricas e culturais (Torres et al, 2014).

É importante, desse modo, pensar historicamente as problemáticas ambientais e as alternativas que se sucedem em diferentes períodos, pois a crise ambiental não é somente do uso da natureza, ou da produção econômica, é, sobretudo, uma questão de conhecimento que problematiza o pensamento metafísico e a racionalidade científica predominante, permitindo novas formas de transformação do conhecimento por meio do diálogo e da hibridização de saberes, conduzindo inclusive à reconstituição de identidades através deste processo de transformação (Leff, 2003).

A expressão "Educação Ambiental" tem sido utilizada como um termo genérico para tudo o que se aproxima das chamadas "boas práticas ou bons comportamentos 
ambientais"; no entanto, essa ideia ingênua pode contribuir para um tipo de apreensão simplista do debate sobre conflitos socioambientais, sobre as orientações e tradições pedagógicas e sobre as pertenças de saberes relativas ao fenômeno da disciplinaridade, pois a mera utilização da expressão não garante uma síntese harmônica desses respectivos conflitos de interesse (Carvalho, 2004). O surgimento de novas orientações educativas que interviessem de modo propositivo na atual crise ecológica e social não adviriam de uma visão ingênua, mas sim crítica da EA. Nesse contexto, a Pedagogia Libertadora de Paulo Freire associada à fase de rompimento de antigos paradigmas da EA tem uma relação positiva a ser estabelecida.

\subsection{Aspectos freireanos da Educação Ambiental}

Ainda que efetivamente analisemos o trabalho de Paulo Freire sob uma perspectiva educativa, é importante considerar que o subsídio para a sua teorização tem forte dimensão antropológica, pois, na tentativa de concretizar um diálogo para a construção de uma educação progressista, aborda os níveis de consciência de alunos e professores (Delizoicov e Delizoicov, 2014). Dessa forma, o projeto políticopedagógico de uma EA crítica assume o objetivo de contribuir com a formação política cidadã de um indivíduo que seja capaz de "ler" seu ambiente e interpretar as relações, os conflitos e os problemas inerentes a ele, por meio de um diagnóstico crítico das questões ambientais e da compreensão do lugar ocupado por esse indivíduo nessas relações (Carvalho, 2004).

Mesmo quando não planejada explicitamente como Educação Ambiental, a prática docente pode ser carregada de várias concepções implícitas, dentre as quais a de meio ambiente, pois a abordagem dos conteúdos pode veicular direta ou indiretamente tais concepções, ocorrendo a promoção da educação ambiental mesmo que este não seja o objetivo direto do planejamento da aula, e os princípios dialógicos e problematizadores presentes no pensamento de Paulo Freire nem estejam delineados (Delizoicov e Delizoicov, 2014). Em um sentido pedagógico, a EA critica a compartimentalização do conhecimento em disciplinas, questiona os territórios de saber/poder já estabilizados disciplinarmente e, em alguma medida, busca a alteração 
de concepções e práticas pedagógicas tradicionais construídas historicamente (Carvalho, 2004).

É o papel pedagógico do diálogo que promove esse movimento e permite a interação entre diferentes práticas culturais, daí residindo a dialética do termo educando-educador e educador-educando e a desqualificação da chamada educação bancária, marcada pela universalização dos conhecimentos a serem transferidos como conteúdos escolares, ausentes de mediações problematizadoras relativas a contradições das distintas práticas culturais (Delizoicov e Delizoicov, 2014).

As práticas educacionais interdisciplinares necessitam de fundamentação conceitual tal que não a configurem somente como uma associação entre opostos, mas que atinjam um limite em que elas, guiadas por conceitos diferentes, tenham resultados efetivos e pilares epistemológicos capazes de embate às antigas leituras maniqueístas e racionalistas e, além disso, as transformem utilizando o viés da complexidade em campos relacionais estreitos entre as disciplinas (Cascino, 1999).

Mesmo que os princípios históricos e legais que sustentem epistemologicamente a Educação Ambiental sejam motivados pela chave da interdisciplinaridade e da complexidade e o campo educativo tenha sido fertilizado por diversas experiências, colocando em prática esses princípios, ainda falta a esse processo de fertilização uma reflexão sobre os fundamentos do saber ambiental e sua influência nessas mesmas práticas educativas: a construção de uma pedagogia ambiental (Leff, 2003).

Tal Pedagogia Ambiental seria resultante da fusão entre a pedagogia crítica e o pensamento da complexidade, sendo caracterizada por um saber que, além do equilíbrio de forças externas, encontra-se nas interações de sujeitos e culturas, nas suas interpretações sobre o mundo e a natureza, resultando na elaboração de saberes significativos, pois o processo de aprendizagem implicaria a internalização de um saber que foi construído social e culturalmente de forma dialógica e multidimensional (Leff, 2003).

Um levantamento realizado em Torres e Delizoicov (2009) apud Torres et al. (2014) nota-se a presença de oito pressupostos freireanos em estudos relacionados à Educação Ambiental, coletados em periódicos e eventos especializados na área: a relação educador-educando, diálogo, tema gerador, o papel do conhecimento, o papel 
da escola, relação sujeito-objeto, conscientização e educação libertadora. No entanto, os autores sinalizam que a simples presença desses pressupostos citados em trabalhos na área não necessariamente reflete uma sintonia com uma perspectiva da Educação Libertadora de Paulo Freire.

A educação acontece, de forma geral, quando atribuímos sentido à experiência humana, transformando natureza em cultura e a trazendo para o campo da aprendizagem, sendo o educador um mediador ou tradutor, pois assume uma tarefa reflexiva de provocar outras leituras sobre a vida, sobre o mundo e sobre nossa ação no mundo (Carvalho, 2014). Há, portanto, uma relação mútua de transformação entre humanidade e natureza que produz seguidamente ambientes de vida e de cultura, já que continuamente listamos as condições naturais vivenciadas em um mundo pessoal de significados, transformando a natureza em traços culturais próprios (Carvalho, 2004).

Nesse âmbito da concepção curricular e da práxis pedagógica, importantes conceitos relativos à prática docente, há algumas possibilidades de configuração de currículos escolares em abordagens temáticas, tais como (a) abordagens pautadas em temas significativos que envolvem contradições sociais; (b) abordagens em temas de enfoque CTS (Ciência, Tecnologia e Sociedade); (c) abordagens balizadas por temas transversais e (d) aquelas pautadas por temas geradores (Freire, 1987), que surgem na perspectiva de contemplar contradições sociais da realidade local, permitindo aos sujeitos envolvidos tornarem-se ativos no processo de ensino e aprendizagem, pela contextualização dos conteúdos (Torres et al., 2014).

É nessa interface escola-comunidade que reside o potencial convergente entre educação formal e não formal da EA e o indicativo dessa relação apresenta-se na forma de vários trabalhos, que estão exatamente nessa fronteira de integração entre escola e entorno, cujos resultados chegam à proposição de novos conteúdos ou orientações pedagógico-curriculares interdisciplinares, que permitem à escola ser vista de forma expandida, estabelecendo novos vínculos de reciprocidade com a comunidade e sua realidade socioambiental (Carvalho, 2004).

A exigência epistemológica da abordagem interdisciplinar para a apreensão da problemática ambiental e a construção curricular da práxis pedagógica é o meio para se pensar uma EA Crítica, necessitando superar a ingenuidade e revelar os diferentes 
matizes curriculares com suas possíveis orientações político-pedagógicas, possibilitando a formação de sujeitos transformadores que pensam e agem criticamente, tornando a escola um espaço capaz de desenvolver sujeitos com uma visão integradora das relações homem-natureza (Silva e Pernambuco, 2014).

Essa tentativa de trazer uma perspectiva interdisciplinar para a compreensão das questões sócio ambientais, em âmbito escolar, possibilita entender como se dão as relações entre as populações humanas e seu ambiente, para poder nelas intervir por meio da conjugação de diferentes conhecimentos - incluindo os não escolares, em casos de comunidades tradicionais - e valorizando a diversidade das culturas, dos modos de percepção e manejo do meio ambiente, a fim de traçar um verdadeiro diálogo de saberes no diagnóstico e na proposição de soluções para essas problemáticas (Carvalho, 2004).

É com essa contextualização que se dá a discussão seguinte, onde expomos as relações entre Educação Popular e Comunitária, sob um viés freireano, em uma perspectiva integradora com Educação Quilombola.

\section{Educação Popular Comunitária/Quilombola em uma perspectiva da Educação Social}

Apresentamos a articulação entre uma Educação Ambiental CríticoTransformadora e os princípios que regem a Educação Popular Comunitária e Quilombola no Brasil. A justificativa para a articulação deste par dialógico será melhor visualizada posteriormente, quando da apresentação do contexto escolar da comunidade estudada e do objeto de pesquisa deste trabalho.

Em um primeiro momento, discutimos o posicionamento da Educação Popular Comunitária e Quilombola, aqui simplesmente denominada Educação Quilombola, no contexto da emergência da Pedagogia Social ou Educação Social. Nesse momento, buscamos evidenciar as associações entre os referenciais teóricos básicos dessas áreas de conhecimento e permitir uma visualização de grupos que, antes desconsiderados, são finalmente reconhecidos efetivamente como novos sujeitos de direito, como o povo negro e quilombola brasileiro, contexto da pesquisa, permitindo um diálogo com a função social da escola pública brasileira. 
Em seguida, procuramos compreender a Educação Quilombola em seus aspectos legais básicos, a conceituação histórica de quilombo, os princípios propositivos que a direcionam para discussões relacionadas à formação de identidade étnica do quilombo no presente e as possíveis articulações teóricas com a Educação Ambiental Crítica, por meio do diálogo de saberes, promotor de um saber ambiental que esteja na interface entre cultura e natureza.

\subsection{Educação Quilombola e sua relação com o desenvolvimento da Pedagogia Social}

Atualmente, a política pública brasileira reconhece, no âmbito educativo, dois parâmetros diversos: o primeiro tendo a Educação como um dever do Estado, correspondendo à garantia de sua oferta e dos meios necessários básicos para sua concretização; e o segundo, a educação como um direito do cidadão, equivalendo ao exercício da condição de sujeitos de direitos (Silva, 2010).

Assumindo a Educação como um direito fundamental, não sendo permitido alguém ser dele excluído, Graciani (2015) argumenta que a extensão do direito à Educação tem sido gradual e progressiva no país. Em sua ideia de inclusão, Graciani (2015) recorre ao referencial teórico e metodológico da Pedagogia Social, que se articula com práticas educativas de Educação Popular, Social e Comunitária, já que sua concepção não pressupõe somente as pessoas portadoras de necessidades educacionais especiais, e, sim, todos os novos sujeitos de direitos atuais.

Entre esses novos sujeitos de direito, referindo-se não à definição jurídica, mas à efetividade da busca pela conquista de igualdade de condições e de direitos, incluise a situação específica relacionada ao povo negro no Brasil e seu acesso a políticas públicas universais, como a Educação. Silva (2013) argumenta que, no pós-abolição, as lutas sociais para a integração do negro esbarraram na dificuldade de acesso da população afro-brasileira a esferas importantes da vida social: o mercado de trabalho e a educação, portanto as desvantagens ocupacionais, habitacionais e territoriais submetidas a essas pessoas foram, e ainda são, fatores importantes para a sua manutenção histórica nos estratos mais baixos educacionais.

Para Silva e Araújo (2005), a história da interdição dos negros aos espaços de conhecimento e aprendizagem oficiais, nos dois séculos anteriores, XIX e XX, gera 
um processo de retroalimentação que, em conjunto com outras interdições, ocasionou uma menor participação efetiva dos negros em diversas esferas da vida urbana e rural, ocasionando prejuízos sociais, econômicos e políticos à população negra atual.

Em sua trajetória histórica, a Pedagogia Social tem evidência no final do século $\mathrm{XIX}$, quando se estabeleceram as bases de uma perspectiva pedagógica orientada aos processos socioeducativos que se articulavam mais fortemente à socialização cultural e a formação de identidades no âmbito da vida em sociedade, posteriormente essa nova área de conhecimento passou a ser chamada Teoria Geral da Educação Social (Machado et al., 2014).

A Pedagogia Social pode ser entendida como uma disciplina pedagógica que se caracteriza por aplicar um enfoque teórico-prático em problemas sócioeducacionais (Machado et al., 2014). O seu objeto de estudo é a Educação Social e seu conteúdo repousa na relação da educação com a sociedade, adquirindo peculiaridade entre as demais disciplinas pedagógicas e de Humanidades por tratar dos problemas sociais sob a ótica educativa.

A Pedagogia Social tem incitado reflexões que são problematizadoras sobre o sentido da formação docente e da prática pedagógica, causando uma expansão das dimensões da educação que extrapola o aspecto técnico, instrucional e escolar. Seu olhar enfatiza o potencial socializador da educação como razão para o enfrentamento de problemáticas sociais (Machado et al., 2014).

Em um contexto internacional, ela é reconhecida como ciência, disciplina curricular, área de intervenção sócio-pedagógica, campo de pesquisa e profissão, enquanto que, no contexto brasileiro, a abordagem prática apresenta-se de forma mais intensa que a teórica, e, apesar dos avanços recentes na visibilidade de trabalhos na área, por décadas houve resistência por parte de educadores escolares ou acadêmicos em relação a diversos aspectos da área, como as relações entre Pedagogia Social, Educação Não Formal e Escola (Machado, E. 2009). No entanto, se reconhecermos a educação popular e sua longa tradição no Brasil como educação social, não podemos afirmar que esta seja realmente uma novidade, talvez a novidade esteja mais no interesse acadêmico em torno da pedagogia social (Gadotti, 2012).

No caso brasileiro, em que a área de Educação, tal como está estruturada, expressa um discurso científico legitimado na organização disciplinar da Pedagogia e 
de suas subdisciplinas, pode-se reconhecer que a Pedagogia Social devidamente, não constitui uma especialidade inscrita nesse âmbito, pois isso se reflete na falta de tradição acadêmica que vincule os referenciais da Pedagogia Social com aportes de crítica na realidade educacional do país (Machado et al. 2014).

Machado, E. (2009) estabelece uma relação importante da educação em sua perspectiva neoliberal, argumentando que a Constituição Federal de 1988 e a Lei de Diretrizes e Bases da Educação Nacional de 1996 fragmentam o conceito de Educação, ao reduzirem a responsabilidade do Estado e da legislação, dando enfoque às questões escolares sem estabelecer critérios para as demais perspectivas educativas, visto que a educação compreende, sim, as dimensões em que a escola se insere, mas as extrapola, gerando consequências para a educação escolar, já que a escola, enquanto espaço formativo, não atende a todas as necessidades educativas que a complexa sociedade atual demanda.

As discussões iniciais da Pedagogia Social no Brasil direcionaram suas reflexões para ambientes não escolares, em processos não formais, mas a relativização desses conceitos leva a uma configuração da área a depender do contexto, já que as questões socioeducacionais não necessariamente estão enquadradas em uma dessas categorias. Para Machado, E. (2009), a Educação a Distância, a Educação Comunitária e a Educação de Jovens e Adultos são claros exemplos que pressupõem intervenções socioeducacionais da Pedagogia Social.

De fato, Gadotti (2012) pressupõe que a educação social, popular e comunitária pode acontecer fora da modalidade educação formal, entretanto, se levarmos em conta seu rigor cientifico, seus fins e objetivos, a necessidade de reconhecimento, regulamentação e certificação, essas práticas são tão formais quanto as outras, não havendo demérito a nenhuma dessas educações e não se estabelecendo fronteiras muito rígidas entre o formal e o não-formal.

De acordo com Silva (2012), em uma visão global da concepção atual de Pedagogia Social, a área está circunscrita a ações educativas desenvolvidas em projetos e programas sociais, públicos ou privados, organizações sociais, populares e comunitárias e práticas de Educação em Saúde, Direitos Humanos, Meio Ambiente, Relações Etnicorraciais etc. Todas são diferentes expressões de Educação Social, podendo ser realizadas dentro ou fora da escola, assumindo uma ou mais questões 
socioeducacionais em suas problemáticas, que giram em torno de quatro grandes domínios conceituais, sejam eles com características socioculturais, sociopedagógicas, sociopolíticas ou epistemológicas.

Pensando, portanto, que a Pedagogia Social tem, em seu bojo de atuação, a emergência de novos povos de direito, tais como o povo negro e a situação educacional diagnosticada nesse setor da população brasileira, é possível nesta pesquisa, a articulação entre Pedagogia Social com seu instrumental teórico e metodológico e a Educação Quilombola mediante o diagnóstico do contexto das comunidades tradicionais sob seus usos de biodiversidade e suas representações sociais de natureza e meio ambiente. Para isso, é preciso apontar legalmente a partir de um conjunto de documentos específicos relativamente recentes, mas ainda não consolidados na prática, as orientações curriculares nacionais da Educação Quilombola.

\subsection{Educação Quilombola e sua relação com a temática socioambiental}

De acordo com o Decreto 4.887/03, art. 2ํㅡㄴ os quilombos são compostos por grupos etnicorraciais por critérios de auto atribuição, levando-se em consideração sua trajetória histórica própria e suas relações territoriais específicas, além da presunção de ancestralidade negra relacionada à resistência à opressão historicamente sofrida (Brasil, 2003a).

Os quilombos são, portanto, uma demonstração de resistência sociopolítica e sociocultural, e estão situados em áreas com características muito marcantes, geralmente rurais e de difícil acesso, com a grande possibilidade de falta de acesso à energia elétrica, água tratada ou a bens e políticas públicas essenciais (Silva et al., 2008).

Historicamente, os remanescentes de quilombo surgiram por processos diversos, que podem ser desde fugas com a posterior ocupação de territórios livres, até heranças, doações ou recebimento de terras por serviços prestados, além da compra de terras (Schmitt et al., 2012).

No presente momento, o quilombo não é mais entendido como um espaço de fuga, como tratado pela historiografia oficial brasileira até a segunda metade do século 
$\mathrm{XX}$, mas sim como uma busca espacial pela construção de um território social e histórico, visando à manutenção e reprodução dos modos de vida que são culturalmente próprios aos seus habitantes, permitindo o reconhecimento da identidade negra brasileira pela autoafirmação etnicorracial (Nascimento, 1980).

Nesse sentido, Leite (2000) argumenta que o quilombo deixa de significar propriamente um passado a ser recontado e passa a ser compreendido como um direito que necessita ser reconhecido, pois a nova dinâmica da territorialização étnica é marcada pela construção da identidade desses grupos, inaugurando uma nova demanda pautada em uma política de formalização da diferenciação étnico-cultural em um âmbito local, regional e nacional.

É nesse contexto que se enquadram as discussões sobre uma educação que valorize as diferenças étnicas e culturais singulares dos povos quilombolas como um processo de trocas e diálogo entre o escrito e o vivido, ou seja, uma educação quilombola cujo enfoque esteja nas relações sociais estabelecidas na cotidianidade, entre os diferentes sujeitos históricos e suas relações com a terra, com a natureza, com o sagrado e suas diversas formas de organização (Nunes, 2006).

A educação escolar oferecida aos remanescentes de quilombo é fruto de uma história de luta por direitos configurando-se em uma série de documentos oficiais que abrangem vários aspectos, desde a cultura até a memória desses povos tradicionais. Dias (2005) apresenta os aportes históricos básicos do processo de criação das leis relacionadas à educação quilombola, desde a Lei de Diretrizes e Bases da Educação (LDB), em 1961 até a Lei 10.639, em 2003. O atual estado da legislação educacional brasileira é decorrente de uma evolução no conjunto de leis que culmina na incorporação da educação escolar quilombola nesse aporte. Destacam-se, nesse processo, a Lei oㅜ 4.024/61, a Lei ㄲo 5.692/71 e a Lei № 9.394/96.

Em 1961, a referida lei ( $n^{\circ}$ 4.024) leva em consideração a questão da raça em discussões e debates da educação, mas fez isso de forma secundária, por não perceber que raça constitui-se como um fator de diferenciação no processo de escolarização (Dias, 2005). Em 1971, a segunda lei citada (nº 5.692); reforma o Ensino Fundamental e Médio e centraliza a discussão no aspecto da profissionalização. Pouco antes, em 1968, a lei oㅜ 5.540/68 havia reformulado o Ensino Superior com base no modelo universitário americano. Essas duas leis representam o ajuste 
educacional ao momento político vivido à época (Figueiredo, 2010). Em 1996, a LDB 9.934 foi pensada em meio a um contexto político onde a participação do movimento negro no processo de sua elaboração deu-se de forma mais acentuada; no entanto, restrita à reformulação do ensino de História do Brasil e à obrigatoriedade, em todos os níveis educacionais, da História das populações negras do Brasil (Figueiredo, 2010).

Em 2003, aconteceu o último avanço na política educacional brasileira sobre o tema aqui tratado, com a publicação da Lei no 10.639, que altera a LDB, nos artigos 26-A, 79-A e 79-B, para incluir, no currículo oficial da Rede de Ensino, a obrigatoriedade do tema "História e Cultura Afro-Brasileira" (Brasil, 2003b). Por história e cultura afro-brasileira entende-se, principalmente, história da África e dos africanos, luta dos negros no Brasil, cultura negra brasileira e o negro na formação da sociedade nacional.

Silva P. (2007) alerta, ainda, que, diante das desigualdades e discriminações que atingem o povo negro, o Conselho Nacional de Educação (CNE) acrescenta, a esse conjunto legal, posicionamentos, recomendações e ordenamentos para a Lei, sob a forma das Diretrizes Curriculares Nacionais para o Ensino de História e Cultura Afro-Brasileira e Africana, o Parecer CNE/CP3/2004 (Brasil, 2004a) e sua respectiva resolução CNE/CP1/2004 (Brasil, 2004b). A Lei 10.639/03, o Parecer CNE03/04 e a resolução CNE01/04 são os instrumentos legais que orientam as instituições educacionais quanto a suas atribuições. Posteriormente, foi lançado o Plano Nacional de Implementação das Diretrizes Curriculares Nacionais para Educação das Relações Etnicorraciais e para o Ensino de História e Cultura Afro-brasileira e Africana, em que há uma seção reservada especificamente a informações sobre a educação em remanescentes de quilombos.

A escola comunitária quilombola necessita de especificidades curriculares adequadas às características de cada comunidade. Tais especificidades passam em igual medida pelo currículo, pelo projeto político-pedagógico, espaços, tempos e temas objetos de ensino, assim como pela família. A convivência com os membros da comunidade, as relações dos comunitários com o trabalho e com o sagrado, as organizações e associações comunitárias e as experiências escolares e dos 
movimentos sociais estão entre os aspectos significativos de sua elaboração (Silva et al., 2008).

Portanto, esse processo de escolarização tem como referência valores sociais, culturais, históricos e econômicos de tais comunidades e a escola que possua territorialidade quilombola deve ser um espaço que efetive um diálogo entre o conhecimento escolar e a realidade social e local, de forma a estimular o desenvolvimento sustentável das comunidades, seu trabalho, sua cultura e a luta pelo direito à terra (Brasil, 2011).

Para garantir que a educação escolar quilombola seja efetivada como um direito, alguns pontos importantes devem ser considerados, como: (a) o Projeto Político Pedagógico e a proposta curricular da escola como instrumentos que se articulem com a comunidade local, (b) a formação inicial e continuada dos professores com base na realidade das comunidades atendidas e, (c) a capacidade da gestão escolar atender às questões específicas dessas comunidades (Brasil, 2011).

Articulando-se tais considerações aos princípios de uma EA Crítica e Emancipatória, e almejando-se melhorar as condições ambientais de existência desses grupos em um processo de valorização de suas ações culturais relacionadas ao manejo do ambiente, compreende-se ambiente como o espaço onde acontece o encontro da natureza com os grupos humanos, justificando denominar essa vertente de EA Comunitária ou Popular (Carvalho, 2004).

A EA no Brasil encontra-se ancorada em pressupostos teórico-metodológicos da Educação Popular, Crítica e Emancipatória (Torres et al., 2014), tais como os princípios apresentados pela Educação Quilombola, ressaltando-se que o direito à educação é básico para a formação da pessoa humana, e os remanescentes de quilombo ainda travam uma luta histórica para conquistá-lo, como garantia de acesso ou de permanência a uma escolarização que considere seus aspectos identitários, culturais, valores e visões de mundo.

Para Carvalho (2004), um projeto crítico de EA tem relação estreita com os ideais emancipadores da educação popular, pois (a) promove a quebra do paradigma de difusão e repasse de conhecimentos, além da abertura da função mediadora do professor na construção coletiva dos conhecimentos, que é um imperativo dessa vertente educativa, formando sujeitos sociais emancipados e comprometidos com a 
compreensão de sua própria história e identidade; e (b) além da sua evidência no ensino formal, compreende muitas práticas que ocorrem fora dos limites da escola, com públicos de diferentes faixas etárias, que não necessariamente o escolar, estando tais atividades diretamente ligadas a conflitos dessas populações com seu entorno ambiental.

É nesse sentido que se articulam, aqui nesta pesquisa, as possíveis intersecções entre Educação Quilombola e Educação Ambiental, em uma perspectiva Histórico-Crítica, sob o pano de fundo dos Saberes Socioambientais presentes no interior da comunidade estudada, pois ambas as áreas guardam estreita relação no que se refere ao rompimento do paradigma epistemológico cientificista moderno, pela construção de estratégias interdisciplinares de produção do conhecimento científico.

Pela construção desse saber ambiental, crítico à disciplinaridade e rearticulador das relações sociedade-natureza, reconfigura-se a visão objetivista das ciências naturais para desenhar um cenário em que os conhecimentos teóricos e práticos possam se alternar entre diferentes fontes culturais, sejam elas científicas, populares ou tradicionais (Leff, 2011).

\section{Contexto da Comunidade e dos Sujeitos Participantes}

Em seu contexto territorial específico, a Comunidade do Mumbuca encontra-se na microrregião do Jalapão que, por sua vez, ocupa uma área de 53,3 mil km² ao leste do Estado do Tocantins, em fronteira com os Estados do Maranhão, Piauí e Bahia, englobando 15 dos 139 municípios tocantinenses. O Parque Estadual do Jalapão (PEJ) pertence à categoria de Unidade de Conservação de Proteção Integral e está inserido na área nuclear do Jalapão, com mais de 158.000 hectares concentrados principalmente no município de Mateiros, com seus limites atingindo ainda os municípios de Ponte Alta do Tocantins, São Felix do Tocantins e Novo Acordo (Naturatins, 2019).

Um dos fatores que confere ao PEJ importante característica de patrimônio ecológico é o fato de ser atravessado por diversas sub-bacias com expressiva quantidade de recursos hídricos para o Rio Tocantins. Essa região do Estado caracteriza-se por um importante vazio demográfico e econômico e uma estrutura 
produtiva relativamente frágil. No entanto, o PEJ apresenta grande importância biológica, pois conta com a presença de espécies raras, endêmicas e em extinção, sendo composto por um mosaico de fitofisionomias que caracterizam o Cerrado brasileiro (Naturatins, 2019).

O PEJ possui uma posição geográfica importante em relação a outras unidades de conservação estabelecidas na região do Jalapão, estando envolvido pela Área de Proteção Ambiental (APA) Jalapão (467.000 hectares) e à relativa distância da Estação Ecológica (ESEC) Serra Geral do Tocantins (716.000 hectares) e do Parque Nacional (PARNA) das Nascentes do Rio Parnaíba (730.000 hectares), constituindo, a região, um importante corredor ecológico de Unidades de Conservação (Figura 1). O PEJ inclui ainda inúmeras belezas cênicas e paisagísticas, além de variados atrativos turísticos de importância ecológica, o que representa um desafio para a gestão do Parque em conciliar o acesso das populações humanas aos atrativos e a conservação da biodiversidade (Naturatins, 2019).

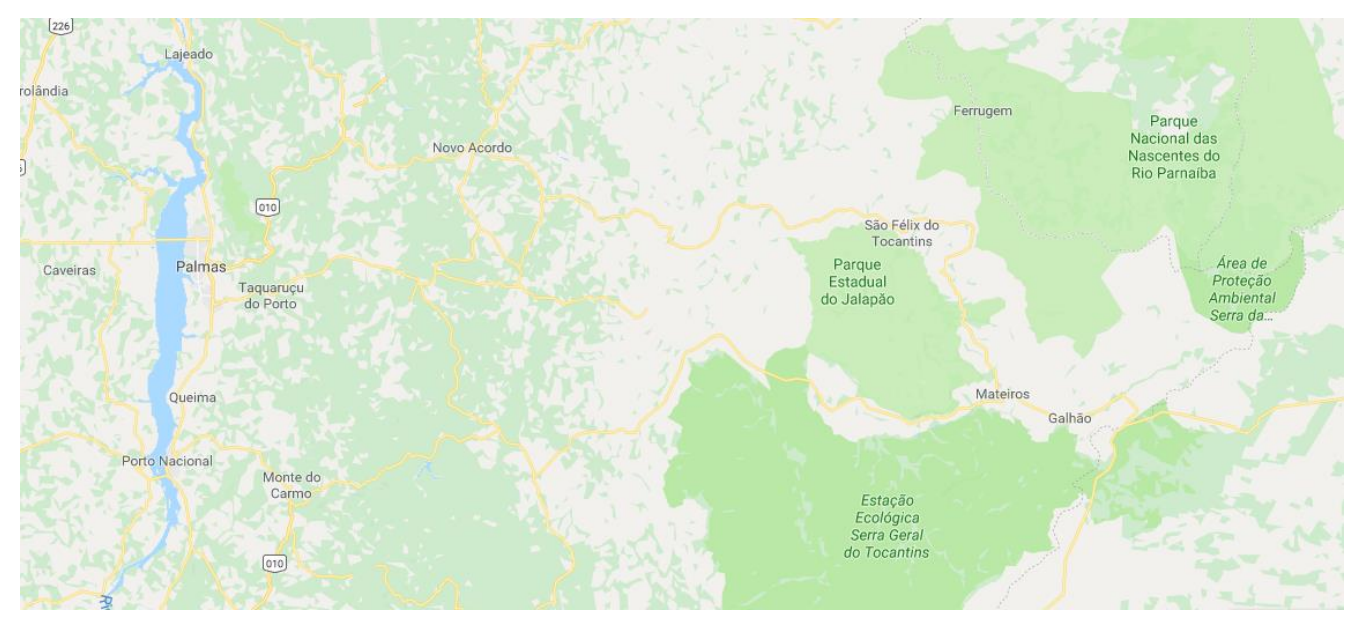

Figura 1. Localização do Parque Estadual do Jalapão (PEJ) evidenciando as cidades circunvizinhas. Fonte: https://www.google.com/maps

A Comunidade do Mumbuca (Figura 2), caracteriza-se por ter, entre as suas principais atividades produtivas e econômicas, o extrativismo de capim-dourado e seda do buriti e, atualmente, viverem um cenário de aprovação e implementação da nova Política de Uso Sustentável dessas espécies, alertando-se que um dos princípios propostos pelo Projeto de Lei (PL) inclui atividades de Educação Ambiental junto às comunidades, em âmbito formal e não formal de ensino. 


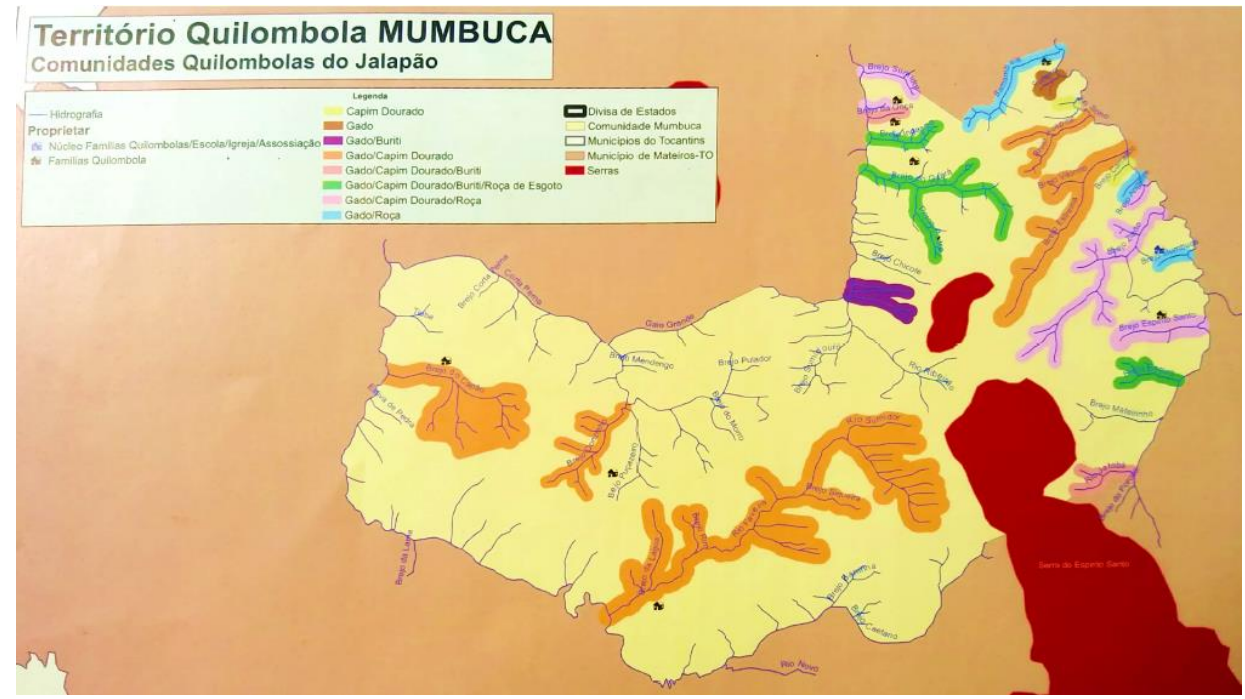

Figura 2. Território Quilombola Mumbuca, evidenciando os principais núcleos familiares em torno da bacia hidrográfica, além das principais atividades produtivas, incluindo gado, capim dourado, buriti e roça de esgoto. Fonte: Boletim Cartografia da Cartografia Social: uma síntese das experiências / Comunidades Quilombolas do Jalapão: os territórios Quilombolas e os conflitos com as unidades de conservação. - N. 5 (Dez, 2016) -. Manaus: UEA Edições, 2016.

No trabalho Diálogos possíveis entre saberes científicos e locais associados ao capim-dourado e ao buriti na região do Jalapão/TO, realizado por Viana (2013) na mesma comunidade desta pesquisa, foi utilizada uma abordagem qualitativa relacionada à Educação Ambiental. Por meio de um diálogo de saberes, foi planejado um projeto envolvendo a população local e promovendo a reflexão dos próprios comunitários como sujeitos participantes da pesquisa. O produto, além de apresentar a articulação entre os saberes locais e científicos associados ao extrativismo das espécies botânicas discutidas, motivou uma discussão sobre o papel da pesquisa participativa como instrumento formativo para os sujeitos envolvidos.

Vale ressaltar que foi no diálogo realizado com os moradores das comunidades que se deu o surgimento da questão de pesquisa sobre a sustentabilidade de sua atividade artesanal, e o objetivo desta se configurou em levantar as percepções dos moradores dos povoados locais em relação às duas espécies vegetais e, a partir desses dados, relativos ao universo desses saberes, realizar a articulação apresentada no título do trabalho (Viana, 2013).

Dados da Seplan (2003) mostram que a Comunidade do Mumbuca, inserido dentro do Parque Estadual do Jalapão, possui pouco mais de 100 habitantes. A comunidade surgiu no final do século XIX, a partir do processo de ocupação da região 
por famílias de negros que fugiam da seca no sertão baiano. Do encontro dessas pessoas com os indígenas da região, surgiu a atual população. Até a metade do século XX, a comunidade manteve-se relativamente isolada devido à distância entre uma das cidades mais próximas ser significativa; Porto Nacional (TO), por exemplo, localiza-se a 294 quilômetros de distância. O nome da comunidade refere-se ao fato de, nessa região, ocorrer um tipo de abelha nativa, chamada popularmente de “abelha-mumbuca” (Faleiro, 2002; Pires e Oliveira, 2006 apud Viana, 2013).

$\mathrm{Na}$ Mumbuca, ou no Mumbuca, como chamam os moradores locais, as moradias eram, em sua maioria construídas artesanalmente. Feitas com paredes de tijolos de adobe, teto de palha de piaçava ou buriti, portas e janelas de buriti e chão de terra batida. Em processo recente, há presença de piso frio e janelas de alumínio em suas casas. A maioria das residências possui três ou quatro cômodos e um fogão à lenha em sua área externa. Hoje, é possível observar que muitas das antigas construções de adobe estão sendo substituídas por alvenaria, além da instalação de energia elétrica e, consequentemente, eletrodomésticos (Viana, 2013).

No âmbito educacional, a primeira escola de toda a região foi criada por volta da década de 1920 e oferecia vagas para estudantes até a $4^{a}$ série do Ensino Fundamental, fator que fez com que a Mumbuca passasse a exercer uma função importante no contexto local (Faleiro, 2002). Hoje, a comunidade possui a Escola Estadual Severino Ribeiro Matos (Figura 3), que atende crianças até o final do Ensino Fundamental, cujos professores são oriundos das cidades próximas à comunidade ou residentes na mesma. Para os estudantes do Ensino Médio, há necessidade de deslocamento com a utilização de transporte escolar até a sede do munícipio, Mateiros (TO), distante 35 km, para continuidade de sua formação escolar básica. 


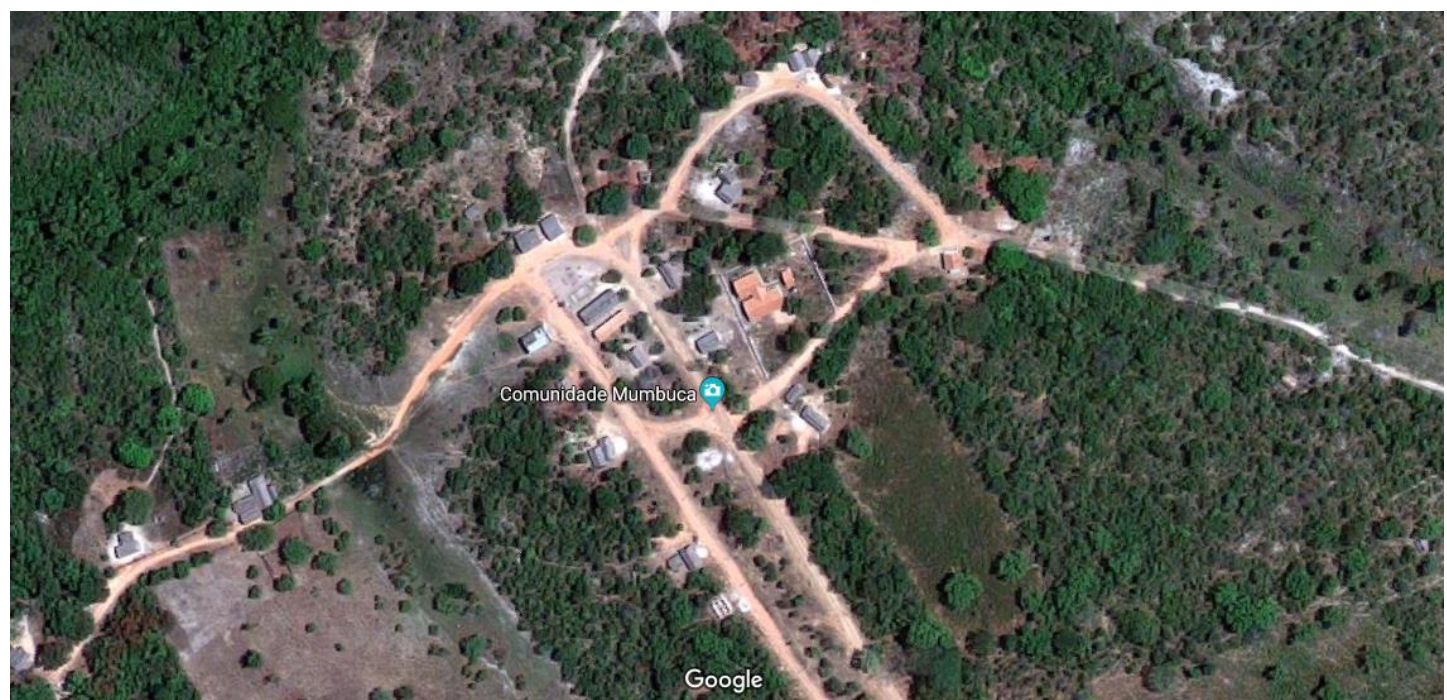

Figura 3. Imagem de satélite da Comunidade do Mumbuca evidenciando as suas principais residências, incluindo a escola comunitária Silvério Ribeiro de Matos. Fonte: https://www.google.com/maps/place/Mumbuca

A Escola Estadual Severino Ribeiro de Matos (Figura 4), enquanto espaço físico, assume posição importante na sociabilidade comunitária, ao lado da Igreja Protestante, da loja da associação de artesãos e dos poucos estabelecimentos comerciais, restaurantes e pousadas presentes na comunidade. Tais espaços, além de algumas residências familiares, são lugares de encontro cotidiano entre as pessoas. De forma geral, a instituição escolar é gerenciada pelos próprios comunitários, pois os professores e coordenadores em sua maioria nasceram, moram ou se hospedam na comunidade, os funcionários da alimentação e serviços de limpeza e portaria são moradores locais, assim como os estudantes são crianças e adolescentes desta e das outras comunidades vizinhas.

A escola representa ainda grande influência sobre o acesso da população à internet, pois há uma rede de acesso para o trabalho administrativo que é compartilhada com os moradores, propiciando a comunicação por meio das novas tecnologias de informação, a realização de pesquisas escolares pelos estudantes, e o compartilhamento de dados e informações pessoais pelos comunitários. Da mesma forma, o transporte escolar que efetua o traslado dos estudantes do Ensino Médio para a sede do munícipio, Mateiros (TO), serve ocasionalmente de recurso para mobilidade de outros moradores que necessitam resolver questões pessoais fora da comunidade. Arquitetonicamente, a escola parece destoar do restante da habitações ao seu redor, parecendo à primeira vista que os muros que a cercam são limitantes 
da possibilidade de articulação com a comunidade. No entanto, com uma observação mais criteriosa, respeitando os limites da formalidade praticada pela instituição, há um estreito vínculo afetivo e social com os moradores da comunidade.

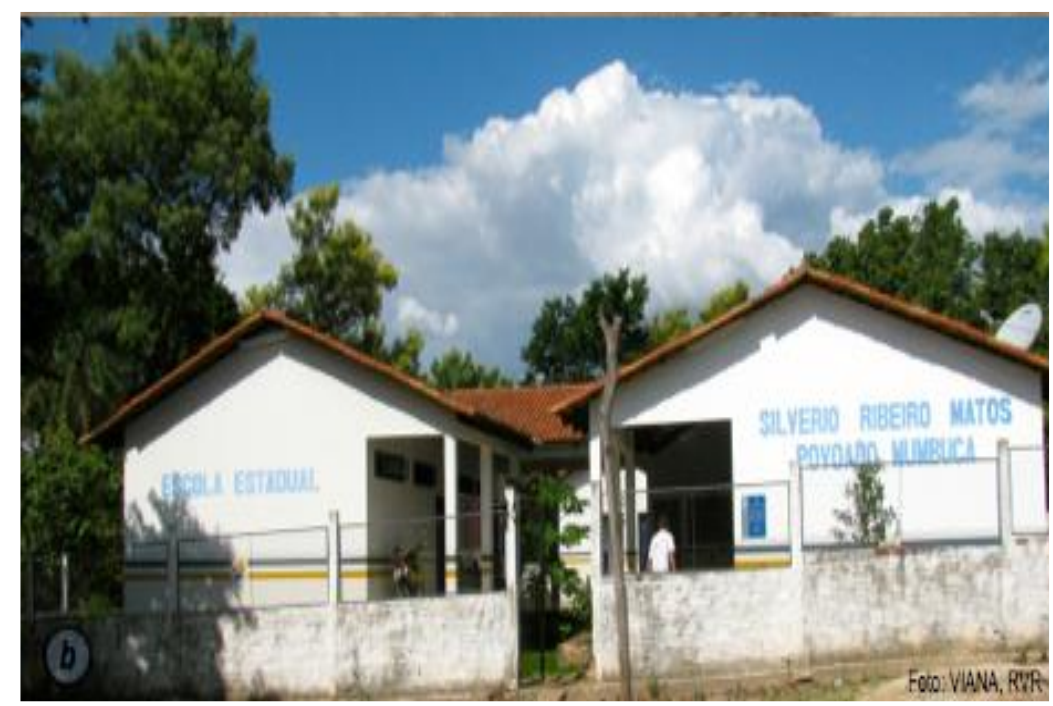

Figura 4. Escola Estadual Silvério Ribeiro Matos - Comunidade do Mumbuca (Viana, 2013)

Durante a primeira visita à comunidade, no contexto deste projeto, para apresentação formal dos pesquisadores e construção coletiva das questões de pesquisa, houve a apresentação de uma demanda pelos professores do Mumbuca: a necessidade formal da incorporação, na grade curricular do Ensino Fundamental, de uma nova disciplina chamada "Saberes e Fazeres Quilombolas". Tal demanda relaciona-se diretamente com Educação Escolar Quilombola e a área original à qual o projeto de pesquisa está vinculado, Ensino de Botânica, aqui compreendida no escopo da Educação Ambiental Crítica, já que a nova disciplina escolar possui, entre seus conteúdos, referências à relação ser humano-natureza vivenciada pelos comunitários, principalmente por meio do trabalho laboral nas práticas agrícolasprodutivas no campo.

Por fim, complementando a contextualização efetuada até aqui no nível regional, comunitário e escolar, necessita-se apresentar, com o devido respeito aos protocolos de ética e termo de consentimento adotados nesta pesquisa, as informações relevantes sobre os sujeitos participantes da pesquisa. Obviamente, outros sujeitos tiveram participação na condução da pesquisa e contribuíram em diversos momentos, seja durante as atividades de campo ou durante a consolidação das aprendizagens acadêmicas, no entanto, esta investigação conta principalmente 
com a participação de quatro sujeitos, entre professores da escola e o pesquisador em formação pelo programa de pós-graduação, que, de forma colaborativa e coparticipativa, discutiram e elaboraram as questões de pesquisa, os métodos de coleta de dados, as possibilidades de resultados úteis para a rotina escolar e o andamento das viagens de campo.

Eu, Ronaldo Andrade dos Santos, sou Licenciado Pleno em Ciências Biológicas pela Universidade Federal do Pará (UFPA), Especialista em Educação para as Relações Etnicorraciais pelo Instituto Federal do Pará (IFPA) e, atualmente, discente e pesquisador proponente desta pesquisa vinculada ao Instituto de Biociências da Universidade de São Paulo (IB - USP). Tenho experiência como professor de Ciências e Biologia para os níveis Fundamental e Médio da Educação Básica e como consultor pedagógico em Ensino de Ciências, utilizando diferentes metodologias ativas de ensino-aprendizagem.

Os três professores participantes da pesquisa possuem Ensino Superior em diferentes áreas na Educação, desde Pedagogia, Licenciatura em Matemática e Educação no Campo. Entre o quadro docente presente na escola, foram eles os profissionais selecionados pela coordenação pedagógica para atuarem no novo componente curricular. Estes docentes realizaram seus cursos de formação em diferentes campus da Universidade do Tocantins (UNITINS), da Universidade Federal do Tocantins (UFT) e outras instituições que oferecem formação complementar à distância. $O$ acesso à internet na escola tem sido fundamental para a formação continuada docente.

Da mesma forma, os professores participantes possuem uma estreita relação com a comunidade, visto que dois deles residem ou possuem familiares no núcleo comunitário e outro deles possui residência fixa na sede do município, Mateiros (TO), mas se hospeda no prédio da escola durante a semana de trabalho estabelecendo vínculos com os comunitários. Os professores que possuem familiares na comunidade, ou que residem na mesma, apresentam importante papel de articulação entre as vivências coletivas comunitárias e a função desempenhada por uma escola imersa em territorialidade quilombola.

Por fim, os professores participantes ensinaram o novo componente curricular, alvo desta pesquisa, aos estudantes do Ensino Fundamental - segundo segmento, 
sexto ao nono anos. No trato da disciplina citada, cada professor foi responsável por ao menos uma série entre as incluídas nesse segmento. Entretanto, em outras séries na mesma escola, os professores poderiam ser titulares de outras disciplinas na grade curricular do Ensino Fundamental, assim como participaram, com sugestões de atividades para a implementação da disciplina nas séries iniciais da escola.

O cronograma de trabalho de campo para andamento da pesquisa permitiu, ao longo das visitas aos professores da escola comunitária, a delimitação $\boldsymbol{b}$ da abordagem e dos procedimentos de pesquisa, fazendo do processo produtivo um instrumento que possa alcançar os objetivos acadêmicos dos pesquisadores e a reflexão sobre a prática pedagógica dos professores em relação a esse novo componente curricular.

Esta pesquisa assume, portanto, a posição de utilizar tal cenário para discutir as relações entre as práticas educativas dos professores, em contexto formal de ensino, com abordagens teóricas e metodológicas advindas da Educação Quilombola e da Educação Ambiental Crítica, tendo como pano de fundo a questão dos usos da biodiversidade na relação ser humano-natureza por estes sujeitos, nos fazeres relacionados à inserção do novo componente curricular na escola comunitária. Imagina-se ser possível associar tais referenciais teóricos e metodológicos por se tratar de um contexto específico de ensino, que permite uma abordagem voltada para a participação ativa dos sujeitos envolvidos no processo de pesquisa. 


\section{QUESTÕES E OBJETIVOS DE PESQUISA}

Nesta pesquisa, discutimos a EA em um contexto formal de ensino, estabelecendo um diálogo de saberes entre as questões identitárias e as socioambientais presentes na comunidade com que trabalhamos, tendo, como ponto de partida, a inserção de um novo componente curricular, "Saberes e Fazeres Quilombolas", ao Ensino Fundamental da escola na Comunidade do Mumbuca.

Objetiva-se

(1) Diagnosticar a realidade educacional apresentada, com a inserção da nova disciplina, articulando-a com EA sob o enfoque citado anteriormente, de forma a transpor os aspectos biológicos da biodiversidade e acrescentar questões antropológicas, culturais, econômicas e políticas.

(2) Sistematizar, a partir desse diagnóstico, possíveis práticas educativas presentes na interface escola-comunidade, a fim de exemplificar como tais práticas ligadas ao trato da temática quilombola podem associar-se dialogicamente a questões socioambientais.

Como objetivos específicos, espera-se:

(1) Interagir com os professores da escola, a fim de identificar, em suas práticas pedagógicas com 0 novo componente curricular, relações de proximidade/distanciamento com as vivências dos estudantes na comunidade em sintonia com questões ambientais locais.

(2) Elaborar, de forma colaborativa, planos de atividades de ensino que atendam às necessidades pedagógicas dos professores participantes e sistematizem as possíveis atividades que podem ser vivenciadas na interface escola-comunidade.

(3) Utilizar o instrumento e os passos metodológicos inerentes à prática da pesquisa, como elemento formativo, tanto dos pesquisadores acadêmicos quanto dos professores da escola, envolvidos como coparticipantes efetivos em todo o processo, por meio da reflexão sobre a sua própria prática.

(4) Fornecer subsídios para continuidade de pesquisas na região em comunidades tradicionais locais, quando da completa criação e consolidação da Política de Uso Sustentável do Capim-dourado e seda do Buriti, já que ela prevê atividades educacionais sobre $o$ tema. 
Questiona-se, então, se as atividades educativas formais vivenciadas e/ou planejadas pelos sujeitos da pesquisa contribuem para o diálogo e a conexão entre os diversos saberes escolares, científicos e comunitários; e qual seria o papel assumido pela escola, por estar inserida na territorialidade quilombola, nesse processo de consolidação de uma práxis pedagógica associada à Educação Ambiental Crítica em um contexto popular, social e comunitário. 


\section{CAMINHOS METODOLÓGICOS}

\section{Pesquisa qualitativa e participante}

Juntamente com os sujeitos envolvidos, docentes da comunidade participante, foi elaborado um Protocolo de Ética na Pesquisa, associado a um Termo de Consentimento Livre e Esclarecido, explicando os objetivos da pesquisa, disponibilizando contatos dos envolvidos no projeto e garantindo sigilo sob os dados obtidos. Foi também construído um protocolo para Notas de campo, a fim de auxiliar o processo de obtenção de dados da pesquisa participante.

O procedimento qualitativo entendido nesta pesquisa apresenta-se como uma relação triangular dialógica na qual o pesquisador negocia consigo mesmo e sua subjetividade, com a comunidade científica e com os sujeitos da pesquisa (Brito e Leonardos, 2001). É importante o reconhecimento de processos subjetivos à pesquisa, envolvendo os modos de aprendizagem e a imersão na realidade por parte do pesquisador. O sentido de participação, aqui entendido, é visto como uma via de mão dupla, com efeitos nos sujeitos da pesquisa e no pesquisador (Esteban, 2010).

A coleta de dados e análise foi realizada a partir de uma abordagem qualitativa e participativa, por meio da qual os diferentes sujeitos são coparticipantes ativos nos encaminhamentos da pesquisa, garantindo que as diferentes visões sobre os fenômenos fossem consideradas (Esteban, 2010), pois, ao longo do processo, além das questões colocadas inicialmente, poderiam surgir outras durante a coleta de dados, tal como aponta Duarte (2002). Essa característica confere uma face flexível e não linear a essa prática de pesquisa (Esteban, 2010).

Para Bogdan e Biklen (1999), historicamente, as investigações do tipo qualitativo assumem variadas formas e podem ser conduzidas em inúmeros contextos, no entanto, existe um conjunto de cinco características que agrupam as investigações neste modelo:

a) Na investigação qualitativa, a fonte direta de dados é o ambiente natural, constituindo o investigador o instrumento principal (Bogdan e Biklen, 1999, p. 47); é importante, nessa abordagem compreender os locais de estudo em seu contexto, realizando as observações no seu ambiente natural de ocorrência. 
b) A investigação qualitativa é descritiva (Bogdan e Biklen, 1999, p. 48); os dados são recolhidos principalmente em forma de palavras, incluindo transcrições de entrevistas, notas de campo, fotografias, documentos, e outros, e a análise dos dados respeita, em grande medida, a forma como eles foram produzidos.

c) Os investigadores qualitativos interessam-se mais pelo processo do que simplesmente pelos resultados e produtos (Bogdan e Biklen, 1999, p. 49); sendo esta característica extremamente útil nas investigações educacionais, permitindo, neste caso, reflexões sobre o processo formativo dos professores.

d) Os investigadores qualitativos tendem a analisar os seus dados de forma indutiva (Bogdan e Biklen, 1999, p. 50); assumindo que, no processo de análise, as questões vão se tornando mais estreitas, pois, ao direcionar a análise após a recolha dos dados e evitando teorias pré-estabelecidas, o investigador vai evidenciando as questões mais importantes.

e) O significado é de importância vital na abordagem qualitativa (Bogdan e Biklen, 1999, p. 50); visto que os investigadores estão preocupados no modo como os diferentes sujeitos participantes da pesquisa dão sentido às suas vidas, diante das questões elaboradas e discutidas sobre os fenômenos observados.

É importante considerar que o sujeito interlocutor não representa somente a condição de sujeito pesquisado, mas sim de portador e porta-voz da experiência narrada, assim como as posições de mediador, tradutor ou intérprete podem ser assumidas pelo pesquisador, marcando o momento do confronto dialógico como aquele em que o "interlocutor transmite sua experiência, interpretando-a (...) a partir de sua posição social, cultural e subjetiva para o pesquisador" (Schmidt, 2006, p. 36).

Para Gianotten e Wit (2010), a participação da comunidade em todo processo da pesquisa e a visão da mesma como sujeito principal da investigação permite a experiência metodológica como uma experiência educativa e estes são princípios básicos inerentes ao desenho metodológico desse tipo de investigação. Esses pressupostos apontam para a necessidade de um perfil de pesquisador que, nas palavras de Duarte (2002), tenha atenção permanente aos seus objetivos, colocandose à escuta do que é dito, refletindo sobre forma e conteúdo das falas obtidas durante as entrevistas. O pesquisador, ainda, precisa estar aberto ao diálogo e tornar claro ao entrevistado seus métodos e os benefícios dos estudos efetuados. 
Schmidt (2006) considera que a pesquisa participante sugere uma inserção de um sujeito pesquisador em um campo de investigação formado pelos aspectos sociais e culturais de outros sujeitos, que são convidados a participar do processo de investigação com alguma medida de colaboração, na qualidade de informantes, colaboradores ou interlocutores, assumindo aspecto central, nessa tarefa metodológica, a produção coletiva e cooperativa do conhecimento, que pode incluir desde a elaboração das questões de pesquisa até os desdobramentos dos resultados da mesma.

Dessa forma, a pesquisa qualitativa de cunho participante,

(...) coloca frente a frente o pesquisador e um outro que, de objeto de estudo e de intervenção passa à condição de sujeito de um conhecimento e agente de uma transformação social (...). A pesquisa é tomada como uma referência histórica que se radicaliza teórica e metodologicamente tanto no questionamento da participação do pesquisador quanto na implementação da participação de grupos institucionais e/ou comunidades populares no planejamento e condução de pesquisas que visam à ação transformadora de coletivos (Schmidt, 2006, p. 16).

A execução do trabalho contou com a realização de cinco viagens de campo para a comunidade (Tabela 1).

A primeira viagem, realizada no primeiro trimestre de 2017, objetivou diagnosticar, entre os professores da comunidade, questões de pesquisa para serem abordadas neste projeto. Nesse momento, iniciou-se a discussão sobre a emergência da nova disciplina "Saberes e Fazeres Quilombolas", pois todos os profissionais consultados fizeram alguma observação sobre o potencial dessa disciplina em ser útil à elaboração de um projeto de pesquisa.

No terceiro trimestre de 2017, a segunda viagem de campo abriu a possibilidade de coleta documental de informações sobre a disciplina estudada, a partir da documentação presente na secretaria escolar, marcando o início de uma discussão com os professores sobre o desejo de elaboração de atividades de ensino como planejamento didático-pedagógico para uso em anos seguintes.

A partir do quarto trimestre de 2017 e primeiro trimestre de 2018, a terceira e quarta viagens, em conjunto, foram úteis para a coleta de dados acerca da disciplina por meio de entrevistas semiestruturadas em profundidade e observação participante sobre a vida em comunidade, em especial a relação entre professores, estudantes e comunidade escolar presentes nesse ambiente. 
Na última viagem de campo, segundo trimestre de 2018, deu-se enfoque na apresentação e discussão das primeiras análises de resultados da pesquisa com os sujeitos envolvidos e na ênfase na abordagem metodológica observação participativa realizada durante a X Festa da Colheita do Capim-Dourado, realizada na comunidade. A partir deste momento, encerrou-se o processo de coleta de dados para prosseguimento desta escrita reiterativa.

Tabela 1. Cronograma de viagens de campo à comunidade do Mumbuca, nos anos letivos de 2017 e 2018.

\begin{tabular}{|c|c|c|}
\hline Ano & Período & Ações desenvolvidas \\
\hline \multirow[t]{3}{*}{2017} & $1^{\circ}$ trimestre & $\begin{array}{l}\text { Viagem exploratória: discussão coletiva sobre as possíveis } \\
\text { questões de pesquisa; } \\
\text { Observação Participativa. }\end{array}$ \\
\hline & $3^{\circ}$ trimestre & $\begin{array}{l}\text { Coleta documental com informações sobre o novo } \\
\text { componente curricular; } \\
\text { Apresentação dos dados pela coordenação escolar e corpo } \\
\text { docente; } \\
\text { Discussão coletiva sobre o desejo de elaboração das } \\
\text { atividades práticas; } \\
\text { Observação Participativa. }\end{array}$ \\
\hline & $4^{\circ}$ trimestre & $\begin{array}{l}\text { Viagem para coleta de dados - Primeiro ciclo de aplicação de } \\
\text { entrevistas semiestruturadas; } \\
\text { Elaboração prévia de três temas de atividades de ensino. }\end{array}$ \\
\hline \multirow[t]{2}{*}{2018} & $1^{\circ}$ trimestre & $\begin{array}{l}\text { Viagem para coleta de dados - Segundo ciclo de aplicação } \\
\text { de entrevistas semiestruturadas; } \\
\text { Elaboração prévia de três temas de atividades de ensino. }\end{array}$ \\
\hline & $3^{\circ}$ trimestre & $\begin{array}{l}\text { Festa da Colheita do Capim Dourado - Apresentação da } \\
\text { pesquisa aos participantes da Festa à convite da organização } \\
\text { do evento; } \\
\text { Observação Participativa. }\end{array}$ \\
\hline
\end{tabular}


Durante as viagens, i. a observação participativa com o preenchimento de notas de campo e ii. a realização de entrevistas semiestruturadas com posterior transcrição em textos dialógicos posteriormente analisados foram empregadas com os sujeitos da pesquisa, a fim de obter as informações necessárias para análise textual discursiva e inferências futuras.

De acordo com Bogban e Biklen (1999), a observação participante e a entrevista em profundidade, também chamada de entrevista semiestruturada, são as estratégias da investigação qualitativa que melhor definem as características deste tipo de metodologia, pois, devido ao seu caráter flexível os sujeitos participantes não necessitam moldar-se a estruturas interrogativas previamente elaboradas e fixas, mas podem responder ao diálogo, baseados em suas experiências e perspectivas pessoais, permitindo maior liberdade de expressão de ideias sobre os assuntos objeto de pesquisa.

\section{Observação participante}

A observação participante constitui-se em uma técnica de investigação que complementa outros métodos, como a entrevista semiestruturada que está sendo empregada neste trabalho. Ela possibilita revelar aspectos novos de um problema, sendo o investigador, ao mesmo tempo, instrumento de coleta e analista dos dados, buscando ampliar sua visão a respeito dos aspectos apresentados em campo, situações e acontecimentos relacionados ao problema e hipóteses da pesquisa (Ludke, M. e André, M. 1986).

Esse aspecto metodológico, apresentado como estratégia de coleta de dados ocorreu nos ambientes comunitários, durante as viagens de campo, incluindo todos os momentos de contato do pesquisador com a comunidade, possibilitando criar um vínculo pessoal entre ambas as partes (André, 1983). As reflexões foram registradas em notas de campo, devidamente organizadas, seguindo um protocolo para a descrição e organização dos acontecimentos vivenciados.

Para Bogdan e Biklen (1999), métodos tais como a observação participante assumem o pressuposto de que, na busca pelo significado, em investigações de cunho qualitativo, o investigador necessite introduzir-se no processo de elaboração 
desses significados pelas pessoas ou grupos sociais estudados, já que, para compreender o comportamento humano, seria "necessário compreender as definições e o processo que está subjacente a construções destas (Bogdan e Biklen, 1999, p. 55)"; processo que não é autônomo, mas coletivo e construído através das interações sociais.

\section{Entrevistas semiestruturadas}

A aplicação de entrevistas semiestruturadas como instrumento de coleta de dados envolve uma discussão planejada pelo entrevistador, mas o direcionamento dado à conversa segue a linha de pensamento do informante-entrevistado, não havendo um questionário rígido ou tempo determinado para a discussão (Duarte, 2002).

A entrevista semiestruturada supõe uma conversa continuada entre os sujeitos, informante e pesquisador, interessando ao pesquisador aquilo que se adequa aos objetivos e domínios da pesquisa (Duarte, 2002). Há necessidade de que os relatos sejam gravados e transcritos, e o método utilizado para obtê-los seja interpretado por diferentes pesquisadores, pois as inferências e os resultados apontados pelo pesquisador tornam-se mais precisos e válidos ao se utilizar dessa estratégia.

As entrevistas nesta pesquisa foram gravadas em áudio com o consentimento do informante-entrevistado. Os dados qualitativos gerados com a aplicação das entrevistas foram organizados e posteriormente categorizados em critérios flexíveis, em consonância com os objetivos da pesquisa. Em seguida, foram analisados sob a ótica de um referencial teórico que permitiu produzir interpretações e explicações para os fenômenos levantados.

A busca e o encontro desse referencial fez parte do processo formativo durante a pós-graduação e também caracteriza o processo qualitativo de pesquisa aqui intencionado, incluindo a escolha das categorias mais significativas para a análise do corpus textual, como um processo de impregnação da literatura especializada da área e direta associação com o material de pesquisa que foi analisado (Moraes e Galiazzi, 2007). 


\title{
4. Análise Textual Discursiva
}

As transcrições das entrevistas realizadas foram submetidas à análise de textos conhecida como Análise Textual Discursiva, que tem em Moraes e Galiazzi (2007) seus principais proponentes teóricos e, por sua natureza qualitativa, figura como uma metodologia de análise de dados e informações cuja finalidade principal é produzir novas compreensões sobre os fenômenos a partir dos discursos.

Em linhas gerais, ela é dividida em três etapas: (1) a desmontagem ou unitarização dos textos que compõem o corpus textual de análise, culminando na produção de unidades constituintes caracterizadas por enunciados extraídos do texto original; (2) o estabelecimento de relação ou categorização, caracterizado pela construção de relações entre as unidades construídas anteriormente, combinando-as em conjuntos que resultam em sistemas de categorias e (3) captação de um novo emergente, entendido como o esforço em tornar explícita uma compreensão do processo de categorização, por meio de um produto ou metatextos criados a partir dos elementos construídos anteriormente (Moraes e Galiazzi, 2007).

O corpus de análise desta pesquisa está definido pela transcrição das entrevistas realizadas durante as viagens de campo, embasado nos documentos oficiais lançados pela Secretaria de Educação como diretrizes para o trabalho com a disciplina objeto de estudo e nas notas de campo escritas pelo pesquisador durante as viagens para a comunidade. Nas próximas seções deste texto, explicitaremos sobre a utilização das categorias de análise.

Em resumo:

\begin{abstract}
"A análise textual discursiva, culminando numa produção de metatextos, pode ser descrita como um processo emergente de compreensão, que se inicia com um movimento de desconstrução, em que os textos do "corpus" são fragmentados e desorganizados, seguindo-se um processo intuitivo auto organizado de reconstrução, com emergência de novas compreensões que, então, necessitam ser comunicadas e validadas cada vez com maior clareza em forma de produções escritas" (Moraes e Galiazzi, 2007, p. 41).
\end{abstract}

Para afirmar o enfoque em uma análise qualitativa, as interpretações produzidas foram compartilhadas com os participantes da pesquisa, como previsto no Protocolo de Ética elaborado no início da mesma, corroborando os resultados descritos, os diferentes métodos de coleta e investigação a fim de garantir sustentação da análise oferecida como produto final. 
Por fim, como estratégia de socialização e encerramento da pesquisa realizada na comunidade, cumprindo a função esperada pelos docentes participantes, sistematizou-se um conjunto de seis atividades educativas que propiciem a aprendizagem significativa a respeito dos temas abordados na visão prática dos professores. Essas atividades, apesar de terem sido planejadas, mas não necessariamente executadas pelos professores no decorrer dos anos letivos de 2017 e 2018, não passaram pelo mesmo processo de análise textual discursiva, por terem sofrido influência direta do pesquisador associado e não representarem unicamente o perfil do coletivo de pensamento representado pelos professores.

$\mathrm{Na}$ próxima seção deste texto, procuraremos dar maior ênfase à discussão sobre a categorização realizada para análise do corpus textual. Tais categorias estão articuladas ao referencial teórico adotado nesta pesquisa e se apresentaram sob duas frentes de análise advindas dos saberes científicos associados à questão e ao contexto de pesquisa.

Vale ressaltar que a categorização, em uma pesquisa de cunho qualitativo como esta, é um processo que acompanha a unitarização do corpus de análise (Moraes e Gallizazi, 2007), portanto, não é demais pensar que elas sofreram mudanças nas diferentes fases da pesquisa, mediante avaliação dos resultados obtidos e triangulação pressuposta na metodologia.

As categorias de análise pensadas para este trabalho repousam nos trabalhos de Fleck (1986), Lorenzetti e Delizoicov (2009) e Sauvé (2004). Nos parágrafos seguintes apresenta-se uma melhor descrição destes pensamentos e a justificativa para utilização dos mesmos nesta investigação.

\subsection{Estilos e Coletivos de Pensamento}

Fleck (1986) denomina estilo de pensamento o conhecimento de uma época, de uma sociedade ou ainda de um grupo, constituído a partir do desenvolvimento das atividades sociais pelo agrupamento social em questão, também chamado de coletivo de pensamento (Condé, 2012). O estilo de pensamento direciona o modo de pensar e agir de determinado grupo social sobre alguma área do conhecimento e o coletivo de pensamento enquadra-se como a própria comunidade de indivíduos que partilham 
de um mesmo estilo, por terem em comum determinadas tradições e práticas (Lorenzetti et al., 2011).

Para a Educação Ambiental, Lorenzetti e Delizoicov (2009) caracterizam dois tipos de Estilos de Pensamento baseados na obra de Fleck (1986), denominados respectivamente de Estilo de Pensamento Ecológico e Estilo de Pensamento CríticoTransformador.

O primeiro, Estilo de Pensamento Ecológico, é fortemente atrelado ao surgimento do movimento ambientalista, tendo enfoque na conservação e preservação de ambientes naturais e assumindo uma tendência comportamentalista, técnica e direcionada à promoção do ensino de ecologia, porventura aproximando-se de uma concepção tradicional de ensino. Os coletivos de pensamento que assumem esse estilo não percebem a EA integrada à educação geral, ficando restrita às disciplinas de Ciências Naturais e Geografia, e os educadores pouco apresentam uma conduta reflexiva política diante dos problemas ambientais e da formação dos seus educandos como cidadãos conscientes e críticos na sociedade, culminando em uma representação social de Meio Ambiente desassociada de questões sócio-históricas (Lorenzetti e Delizoicov, 2009).

Em contrapartida, o Estilo de Pensamento Ambiental Crítico - Transformador articula múltiplas faces do processo educativo e assume as problemáticas ambientais em diferentes dimensões, desde as naturais até as sociais, culturais e políticas. Essa abordagem prevê, portanto, a formação de cidadãos críticos por meio de uma relação educativa democrática e globalizante, firmada em princípios da transdisciplinaridade, com uma amplitude de olhar maior em relação ao primeiro estilo. Esse estilo de pensamento atribui as diferentes dimensões humanas às questões ambientais, caracterizando uma EA que permite uma maior integração entre seres humanos e a natureza, em uma visão não ingênua de meio ambiente, agora entendido como o espaço da inter-relação dos diferentes elementos naturais e sociais (Lorenzetti e Delizoicov, 2009). 


\subsection{Diferentes Correntes em Educação Ambiental}

Sauvé (2004) reflete sobre os diferentes discursos em Educação Ambiental e sobre como propõem diversas concepções e práticas de ações nessa área. Tais discursos e modos de ação foram caracterizados e agrupados em conjuntos que demonstram o que autora denominou de "correntes" em Educação Ambiental; a tais correntes, com características específicas que as distinguem ou as aproximam umas das outras, cabe uma pluralidade de elos não excludentes, pois uma mesma proposição pode estar presente em diferentes correntes ou em uma única corrente pode haver proposições diversas.

Historicamente, podem ser divididas como correntes de longa tradição, que foram predominantes nos anos 1970 e 1980, e correntes recentes, com o viés atual de mudanças paradigmáticas sobre o campo social. Os principais parâmetros para determinação dessas correntes são: (a) tipo de concepção dominante sobre meio ambiente; (b) intenção da ação educativa; (c) principais enfoques privilegiados e (d) modelos que exemplificam a corrente (Sauvé, 2004).

Dessa forma, seu trabalho apresenta atualmente 15 correntes em Educação Ambiental, que podem ser empregadas em projetos de pesquisa ou ações educativas diretas. Sete destas são as correntes de longa tradição, como a naturalista, a conservacionista/recursista, a resolutiva, a sistêmica, a científica, a humanista e a moral/ética. As demais oito correntes estão entre as mais recentes, ilustradas pelas correntes holística, biorregionalista, práxica, crítica, feminista, etnográfica, da ecoeducação e da sustentabilidade (Sauvé, 2004).

Imagina-se ter sido possível identificar, nos dizeres dos professores entrevistados sobre "Saberes e Fazeres Quilombolas", algumas dessas correntes concebidas por Sauvé (2004), a fim de atingir os objetivos da pesquisa no que se refere principalmente aos diagnósticos da realidade educacional apresentados com a inserção da nova disciplina escolar.

\subsection{O agrupamento das categorias}

Os Estilos de Pensamento para EA, precisamente o Estilo de Pensamento Crítico-Transformador (Lorenzetti e Delizoicov, 2009; Fleck, 1986) e as quinze 
correntes em Educação Ambiental (Sauvé, 2004) justificam-se como sistemas de argumentação neste trabalho, por demonstrarem em diferentes medidas, uma evolução histórica epistemológica sobre concepções de meio ambiente e práticas pedagógicas relacionadas à EA. Avaliamos que a utilização dessas categorias satisfez a necessidade da pesquisa em diagnosticar a prática pedagógica dos professores entrevistados e discutir sobre o tipo de EA que pode ser desenvolvida, usando como ignição a nova disciplina "Saberes e Fazeres Quilombolas", em uma perspectiva de diálogo de saberes na interface escola-comunidade dentro do contexto apresentado.

Os esquemas a seguir (Figuras 5 e 6) apresentam uma melhor visualização do processo de coleta dos dados e análise a partir da categorias citadas, assim como do processo de produção dos metatextos que serão discutidos nos resultados desta pesquisa. Eles observam os momentos de entrevistas semiestruturadas, seguidos da produção de metatextos temáticos que incluem a transcrição das interlocuções apresentadas pelos professores participantes, associados aos argumentos apresentados no sistema de categorias. Objetivou-se, nesses momentos, identificar, no discurso coletivo, as representações em suas falas que pudessem ser associadas aos pressupostos do Estilo de Pensamento Crítico-Transformador e das diferentes Correntes de Educação Ambiental, tendo em vista a elaboração dos metatextos temáticos que representam o coletivo de pensamento dos docentes.

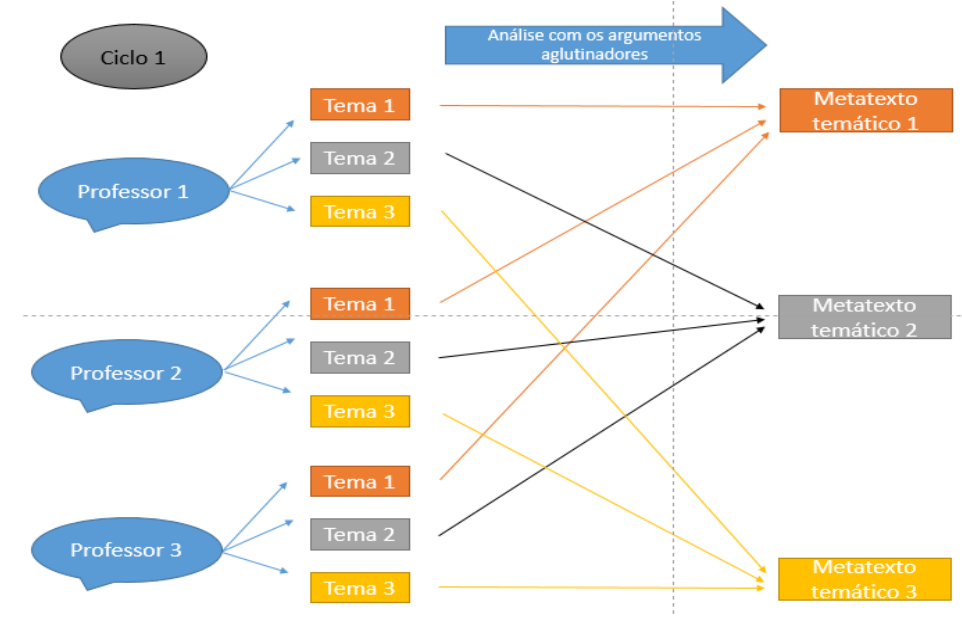

Figura 5. Sistematização do processo de produção dos metatextos a partir do primeiro ciclo de entrevistas em profundidade. 


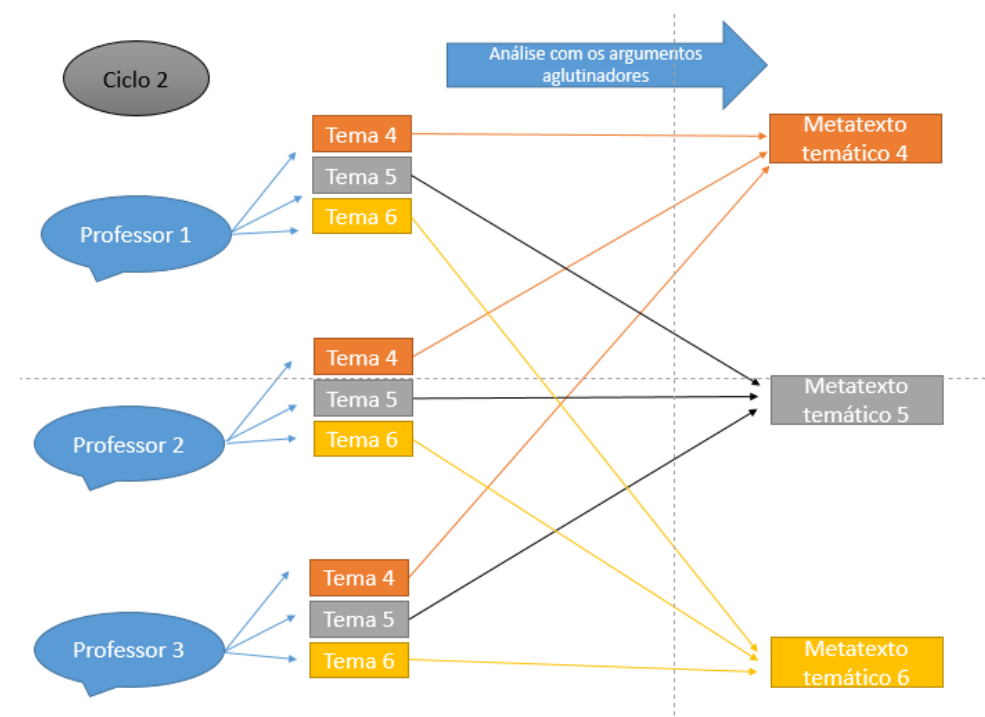

Figura 6. Sistematização do processo de processo de produção de metatextos a partir do segundo ciclo de entrevistas em profundidade

Em outras palavras, o processo de produção dos metatextos temáticos buscou identificar, nas interlocuções dos professores, componentes relacionados ao Estilo de Pensamento Crítico-Transformador (Lorenzetti e Delizoicov, 2009; Fleck, 1986), por entender que esse é o pressuposto básico que dialoga com a EA na perspectiva adotada por este trabalho, e componentes que se articulem a uma ou mais Correntes de Educação Ambiental, presentes no trabalho de Sauvé (2004), para traçar um perfil das possíveis práticas de EA presentes nesta interface escola-comunidade.

Admite-se que esse diagnóstico pode provocar uma abertura para identificar, entre os atributos da EA, na prática educativa em torno da disciplina, abordagens implícitas baseadas no pensamento de Paulo Freire, tais como:

(...) o trabalho coletivo, a contextualização dos problemas locais, a relação entre escola e comunidade através de processos educativos participativos, a relação entre a dimensão local e global, a interdisciplinaridade, a produção e a disseminação de materiais didático-pedagógicos, a relação entre a dimensão individual/coletivo, a perspectiva crítica e problematizadora do conhecimento, a abordagem globalizante de meio ambiente, a cooperação, o respeito, a solidariedade, a igualdade. (Torres et al., 2014)

Por fim, as utilizações dessas categorias de análise são úteis para observar a coerência entre uma prática de EA baseada em princípios histórico-críticos. Torres et al. (2014) baseiam tal concepção por meio dos seguintes critérios: (a) articulação do conteúdo escolar com a vida da comunidade; (b) aplicação cotidiana do conteúdo aprendido; (c) projeto político-pedagógico construído de maneira coletiva; (d) 
estreitamento de relações entre escola-comunidade e (e) possibilidade de o educador refletir sistematicamente sobre sua prática docente.

A partir disso, passamos a apresentar (I) a produção dos metatextos finais referentes à execução da Análise Textual Discursiva sobre as entrevistas e (II) a sistematização dos planos de atividades de ensino realizadas no conjunto pesquisador-professores, que foram pensadas ao longo dos anos letivos de 2017 e 2018, assim como a discussão sobre esses resultados à luz da elaboração de uma Educação Ambiental subjacente à chave dos Saberes e Fazeres Quilombolas, diante do conceito de Saber Ambiental presente no trabalho de Leff $(2001$; 2011) e da Pedagogia Freireana. A matriz de referência do componente curricular oferecida aos professores como subsídio para o trabalho pedagógico encontra-se como anexo, ao final desta dissertação. 


\section{O NOVO EMERGENTE ARTICULADO ÀS CATEGORIAS DE ANÁLISE}

Os resultados da pesquisa podem ser subdivididos em dois conjuntos distintos: (I) o primeiro formado pela obtenção do corpus textual de análise a partir das entrevistas semiestruturadas aplicadas durante as viagens de campo e da coleta documental realizada na escola, e (II) o segundo, proveniente também dos encontros com os professores em campo, trata-se de uma contrapartida da pesquisa como iniciativa de fomento ao trabalho docente, com a sistematização de atividades de ensino em decorrência da necessidade de produção de material didático para uso na disciplina objeto de estudo da pesquisa.

(I) Melhor descrevendo os resultados relacionados a construção do corpus de análise, divide-se a produção desses textos em dois momentos vivenciados a partir da segunda viagem de campo: (a) primeiro, a obtenção de cópias dos documentos oficiais, ementa da disciplina Saberes e Fazeres Quilombolas, com o suporte da coordenação pedagógica da escola; (b) segundo, a aplicação das entrevistas semiestruturadas, individualmente, que foram pensadas sem um roteiro fixo direcionando a conversa com os professores, mas com a escolha de grandes temas que poderiam atingir os objetivos da pesquisa. Essas conversas com os professores foram realizadas em diferentes ambientes, desde suas próprias casas na Comunidade do Mumbuca ou na cidade de Mateiros (TO) a outros espaços no interior da comunidade, como a Escola Severino Ribeiro Matos e o roçado particular da família de uma professora.

Foi obtida uma discussão sobre seis grandes temas relevantes para entender o papel pedagógico que a nova disciplina tem adquirido no contexto escolar, na tentativa de reconhecer o potencial da mesma em discutir questões pertinentes a saberes socioambientais. Os tópicos gerais das entrevistas são apresentados a seguir, em ordem de discussão ao longo das viagens de campo:

No primeiro ciclo de entrevistas, os temas discutidos com os docentes foram: (a) importância da disciplina Saberes e Fazeres Quilombolas para o profissional, analisando o contexto local e dos estudantes; (b) estratégias de trabalho com a disciplina, em especial questões sobre o acesso a materiais didático-pedagógicos que foram utilizados durante o ano letivo e que tipo de pesquisa bibliográfica foi realizada; 
(c) relação que o professor estabelece entre o saber presente na disciplina e questões socioambientais locais.

No segundo ciclo de entrevistas, assuntos derivados dos primeiros foram aprofundados e novas temáticas de discussão surgiram através da imersão realizada na literatura ao longo da obtenção de créditos em disciplinas. Os tópicos discutidos nesse segundo momento foram: (d) avaliação pessoal dos principais desafios e conquistas que foram vivenciados na implementação curricular da disciplina pela primeira vez; (e) apontamento sobre outros espaços e relações sociais comunitárias com possibilidade de aprender e ensinar "Saberes e Fazeres Quilombolas", que não sejam diretamente associados ao espaço físico da escola; e uma extensão do item anterior foi uma abordagem sobre a (f) proveniência dos assuntos discutidos em sala, buscando entender se houve participação direta dos alunos em sugestões temáticas ou se a abordagem seguiu os parâmetros definidos nos documentos oficiais.

As entrevistas aplicadas totalizam, aproximadamente, 134 minutos de áudios gravados e 43 páginas transcritas. As transcrições foram sistematizadas em unidades de significado, como previsto na metodologia de Análise Textual Discursiva (Moraes e Galiazzi, 2007), para análise pelo uso de categorias derivadas do referencial teórico inspiradas entre as correntes de Educação Ambiental (Sauvé, 2004) e aos Estilos de Pensamento em Educação Ambiental (Fleck, 1986 apud Lorenzetti e Delizoicov, 2009).

(II) Uma preocupação evidenciada em todas as interações de campo com os docentes foi o fato de que eles não tinham acesso a materiais didático-pedagógicos direcionados especificamente, para o trato das questões sugeridas pela disciplina e necessitarem assumir uma postura de pesquisa constante na busca de referências teóricas, sejam formalmente escritas para esse fim ou oriundas das próprias relações estabelecidas na comunidade, que permitissem a melhoria de seu trabalho em sala de aula e aprendizagem significativa para os estudantes.

Diante desse fato, como produto alternativo à pesquisa e assumindo uma contrapartida interessante para o corpo pedagógico da escola, surgiu entre os docentes a ideia de levantamento e sistematização de atividades de ensino elaboradas, mas não necessariamente executadas, no decorrer do ano letivo, a fim de obter, ao final, um roteiro elaborado coletivamente que os auxiliem 
pedagogicamente nos anos letivos seguintes, já que não há expectativa de término do oferecimento da disciplina na grade curricular oficial da escola. Nos ciclos de entrevistas, descritos anteriormente, cada professor apresentou ao menos uma sugestão de atividade de ensino que foi planejada para ser executada na série do Ensino Fundamental pela qual o respectivo docente se responsabilizava.

No primeiro ciclo de entrevistas, obtivemos duas sugestões de atividades, cujos temas são: (a) tema 1 - Roça de Esgoto/Toco direcionada aos estudantes do $7^{0}$ do Ensino Fundamental como uma discussão sobre os aspectos agrícolas envolvidos nesse de tipo de roçado; (b) tema 2 - Conservação Socioambiental associada à preservação de rios e nascentes, direcionada aos estudantes do 8 $^{\circ}$ ano do Ensino Fundamental.

No segundo ciclo de entrevistas, obtivemos quatro sugestões de atividades: (d) tema 3 - Oficinas de utensílios domésticos utilizados tradicionalmente pelos comunitários e que estão caindo em desuso pelas novas gerações, direcionada aos estudantes do $7^{\circ}$ ano do Ensino Fundamental; (e) tema 4 - Confecção da "Caixinha de Segredo", com palha de coco piaçava, objeto produzido manualmente que pode ser utilizado como brinquedo pelas crianças de menor idade; ( $f$ ) tema 5 - Visita guiada às "Dunas", atrativo turístico da região, direcionada aos estudantes do $9^{\circ}$ ano do Ensino Fundamental, em uma possível relação com os aspectos geográficos, turísticos e ecológicos e (g) tema 6 - Atividade prática, em campo, sobre identificação dos frutos presentes no cerrado.

Nas páginas seguintes, serão apresentadas essas seções de resultados: a primeira contendo os seis metatextos produzidos, seguidos da apresentação de tabelas contendo citações diretas das interlocuções docentes associadas a inferências subjetivas baseadas na impregnação sob o escopo teórico da pesquisa; e a segunda, apresentando as sugestões de atividades de ensino com vistas a permitir uma integração entre saberes associados à cultura e identidade quilombola com questões socioambientais locais. 


\title{
1. Metatextos temáticos
}

\subsection{Importância da disciplina}

\begin{abstract}
"Uma das tarefas mais importantes da prática educativo-crítica é propiciar as condições em que os educandos em suas relações uns com os outros e todos com o professor ou a professora ensaiam a experiência profunda de assumirse. (...) A questão da identidade cultural, de que fazem parte a dimensão individual e a de classe dos educandos cujo respeito é absolutamente fundamental na prática educativa progressista, é problema que não pode ser desprezado" (Freire, P. 1996, p. 46-7).
\end{abstract}

É marcante, no discurso dos professores quando refletem sobre a importância da disciplina Saberes e Fazeres Quilombolas, no contexto da Escola Comunitária em que atuam como docentes, a ênfase nos aspectos histórico-sociais sobre a construção da identidade quilombola, visto que estabelecem uma relação temporal das vivências dos comunitários desde as formas de sobrevivência empregadas pelos seus antepassados, primeiros habitantes da região, incluindo as diferentes práticas agrícolas-produtivas, até as formas de socialização atualmente exercidas pelas novas gerações, como a relação com a tecnologia e o acesso à comunicação, à energia elétrica, novas oportunidades de deslocamento e transporte que alteraram as visões de mundo das pessoas.

O posicionamento apresentado pelos professores, ao refletirem sobre a questão, versa sobre a valorização dos saberes tradicionais da comunidade, de forma a desejar a preservação das tradições relacionadas à cultura quilombola, dando ênfase à ligação desse povo com o mundo do trabalho e as práticas laborais desenvolvidas historicamente e coletivamente pelos seus descendentes, ligadas à agricultura de subsistência como principal forma de sobrevivência e à utilização de elementos naturais no suporte a esses mecanismos.

A relação estabelecida pelos professores entre o lugar que habitam, a comunidade circunscrita no Cerrado, e as estratégias de sobrevivência empregadas pelos seus antepassados pode ser um indicativo de uma concepção de lugar/ambiente que não se apresente afastada da relação com os seres humanos, mas associada às estruturas sociais por eles estabelecidas.

Emerge daí o sentido da valorização da identidade quilombola, dando importância aos valores e códigos culturais construídos por essa sociedade. Traz-se 
a tônica do discurso para expressões que posicionem uma valorização cultural dos conhecimentos tradicionais comunitários quilombolas e o sentido de resgate desses saberes, atribuído como função dos diferentes núcleos familiares e da escola, por meio de sua práxis educativa.

Existe uma percepção prática do trabalho com o novo componente curricular visando à elaboração de atividades que ilustrem, por exemplo, os hábitos alimentares dos antepassados da comunidade, que incluíam a experiência com a natureza, o cultivo de determinadas espécies vegetais, e a possibilidade de discutir questões ligadas à saúde humana e ambiental, por meio da articulação de conhecimentos escolares e comunitários.

O processo de ressignificação cultural apresentado pelas atuais gerações na comunidade, em grande medida é associado a mudanças sociais, espaciais, tecnológicas e de comunicação. Os novos códigos culturais vivenciados e construídos pela juventude comunitária, as características sociais dos fundadores da comunidade e a avaliação das novas relações com o meio, estabelecidas entre as diferentes gerações de moradores, são diagnosticados como efetivas mudanças temporais pelos docentes e permite entender a interação ser humano - meio ambiente como construtora de simbologias a partir das possibilidades de vivências coletivas nesse meio.

Ao trazer para a sala de aula suas memórias pessoais e representações sociais que são transmitidas oralmente entre as diferentes gerações na comunidade, há uma tentativa dos professores de dar voz ao passado e compreender as relações socioambientais do presente, por meio do que já foi elaborado historicamente em momentos anteriores pelos comunitários.

Há, dessa forma, uma tendência no discurso dos professores em abordar as questões ligadas ao trato da disciplina Saberes e Fazeres Quilombolas, sob um ponto de vista temporal identitário, que leva em consideração aspectos culturais construídos localmente ao longo da história da comunidade e as possíveis transformações nesses códigos e simbologias acarretadas pelas mudanças socioculturais, implicadas na relação com o meio ambiente, diante das novidades tecnológicas acessadas pelas novas gerações. 
Os professores, em seu discurso, trazem uma associação clara no processo de transmissão cultural geracional pela oralidade, sobre os hábitos e costumes antigos de seu povo e a ressignificação de tais costumes atualmente. Esses hábitos relativos à produção de elementos da cultura quilombola estão associados, entre outros, à rotina alimentar comunitária e aos elementos da biodiversidade local que são utilizados neste processo.

Tal perspectiva de trabalho abre-se a um constante fluxo de informações e saberes entre a Educação Formal, aqui representada na relação professores e estudantes, e a Educação Informal, representada na troca estabelecida entre os alunos e seus familiares, sobre os temas tratados em sala de aula, que contribuem para a apreensão dos novos aprendizados discutidos em torno da nova disciplina curricular. $\mathrm{Na}$ interface escola-comunidade, fortalecida pela práxis pedagógica dos educadores, apresenta-se um indicativo de caracterização de uma Educação que dialogue com as experiências sociais dos comunitários participantes e permita uma constante troca de saberes entre os sujeitos.

Ressalta-se, dessa forma, a ênfase da escola como mediadora da educação formal com a educação comunitária, assumindo o papel de trazer as discussões relacionadas às práticas sociais tradicionais, usando elementos da biodiversidade para a subsistência básica, como transporte, produção de alimentos, utensílios domésticos, dentre outros, para dentro do processo formativo educacional, sem intencionar ocupar o lugar da aprendizagem social do interior da comunidade. Essa estratégia, típica de uma escola com territorialidade quilombola, permite uma interseção entre as práticas de ensino-aprendizagem vivenciadas a partir da oralidade, nos diferentes núcleos familiares, e a sistematização desses saberes em conhecimentos escolarizados pelos profissionais envolvidos com a elaboração curricular da nova disciplina.

Outro aspecto que merece atenção na perspectiva de trabalho dos docentes, é o fato de que as aulas sejam potencialmente dialógicas e participativas, em uma concepção menos tradicional de ensino, havendo um entendimento de que os saberes associados à disciplina estão presentes nas experiências cotidianas dos alunos, podendo-se considerar que, durante as aulas, os momentos de troca de experiências e saberes entre os diferentes sujeitos do ambiente escolar tornem-se oportunos. $O$ 
intercâmbio de informações das experiências individuais e coletivas entre professores e estudantes, que constituem diferentes gerações da comunidade, atribuem uma noção cíclico-temporal do fluxo de saberes na sala de aula.

Nesse primeiro momento, pode-se identificar que as estratégias de ensino utilizadas pelos professores dialogam com uma perspectiva de trabalho educativo que esteja associada à troca de experiências, privilegiando a aprendizagem coletiva, em que os estudantes parecem ser estimulados a conversar sobre os assuntos discutidos e a assumir um posicionamento crítico diante discussões abertas sobre as temáticas, evidenciando pontos de vista pessoais, comunitários e externos à comunidade.

O reforço positivo a essa postura pedagógica adere-se ao caráter cultural de transmissão oral de saberes quilombolas e posiciona o núcleo familiar como importante construtor das identidades dos sujeitos. Essa postura dialógica, valorizadora das histórias orais no ambiente de ensino, acontece em diferentes interlocuções dos professores e aborda as questões de estudo de forma ampla, colocando os indivíduos e a coletividade comunitária no centro do debate a respeito das temáticas previstas e abordadas em sala.

Por fim, evidencia-se também, nas interlocuções dos professores, uma preocupação sobre as diferentes cadeias produtivas relacionadas ao contexto geográfico dos comunitários, extrapolando a relação com alimentação em um sentido cultural-local e estabelecendo-se uma distinção entre os diferentes tipos de produção de alimentos oriundos de uma agricultura familiar-quilombola ou provenientes dos grandes empreendimentos na região, ressaltando as diferentes consequências para o meio ambiente das práticas exercidas nos diferentes locais, tornando-se evidente uma articulação com concepções ligadas à sustentabilidade das práticas produtivas, aos impactos sobre a saúde humana e ambiental, e à menor ou maior conservação ambiental associada a essas diferentes práticas produtivas.

$\mathrm{Na}$ tabela 2, encontram-se trechos das interlocuções dos profissionais associadas a interpretações baseadas no referencial teórico adotado neste trabalho e na subjetividade do pesquisador/analista, permitindo melhor visualização sobre a discussão apresentada neste metatexto temático. 
Tabela 2. Quadro analítico do metatexto I - Importância da disciplina.

Possibilidade de o
educador refletir sobre
sua prática docente e
sobre o papel dos
conhecimentos
trabalhados para a
formação cidadã dos
estudantes,
posicionando na escola
função importante de
discussão sobre a
territorialidade
quilombola.

Estabelecimento de vínculos de reciprocidade entre escola e comunidade, por meio do diálogo entre as diferentes vozes deste contexto. Énfase na aplicação cotidiana dos conteúdos aprendidos e na discussão sobre o papel do currículo escolar oficial na mediação entre as vivências comunitárias e a práxis pedagógica no ambiente escolar.
“(...) Essa disciplina é um resgate, dá valores a esses Saberes e Fazeres dessas comunidades (...) alguns Saberes e Fazeres que tão até esquecidos. Então é isso um resgate, porque acham assim, isso não é importante (...) dá assim uma certeza do porquê nós estamos hoje, por que nós estamos aqui hoje, por quê? Teve um povo forte que lutou, que superou as adversidades e dificuldades que tinha né? Com poucas coisas que tinha sobreviveram e permaneceram até hoje (...) vamo... chegou a tecnologia, chegou a energia, chegou 0 transporte, então muitas coisas deixam de ser feito dentro da própria comunidade por causa de muitas facilidades que já chegou (...)"

“(...)Teve uma menina que falou assim 'Olha, minha vó nunca contou isso, eu vou perguntar a minha vó'. Chegou lá a vó contou e 'Professora, minha vó contou igual a senhora falou, professora'. Então assim, é interessante a gente perceber que tá esquecido, realmente tá esquecido. (...)"

“(...) ela não é muito difícil pra gente desenvolver né? Tem a prática né? A aula prática que a gente pode ir num lugar, num ambiente, ver como é que faz, como é que tem que fazer e é uma disciplina também de sala de aula que a gente tem as explicação que como eram os povos antigos né? (...) é uma disciplina nova que entrou no currículo, é muito importante porque primeiramente são... são disciplinas que é o saberes que a gente nunca pode deixar esquecido né? Eu achei muito importante porque uma coisa é um trabalho, é uma cultura que cada vez 


\begin{tabular}{|c|c|}
\hline & $\begin{array}{l}\text { mais as pessoas tem que desenvolver, tem que voltar } \\
\text { àquela vida né? (...)" }\end{array}$ \\
\hline $\begin{array}{l}\text { Discussão sobre os } \\
\text { diferentes usos da } \\
\text { biodiversidade vegetal, } \\
\text { com uma perspectiva de } \\
\text { inserção da temática } \\
\text { relacionada à saúde } \\
\text { alimentar. }\end{array}$ & $\begin{array}{l}\text { "(...) Um desenvolvimento assim, muitas vezes de } \\
\text { alimentação, que é uma coisa mais sobrenatural, uma } \\
\text { alimentação. Porque as coisas tudo, não tá vindo mais } \\
\text { assim natural né? Mas desde já quando a gente planta } \\
\text { uma mandioca né? Planta o arroz, planta uma batata ela } \\
\text { já não vem com tanta química porque já é produtos mais } \\
\text { natural. (...)" }\end{array}$ \\
\hline $\begin{array}{l}\text { Diferentes usos da } \\
\text { biodiversidade vegetal, } \\
\text { desta vez enfatizando a } \\
\text { relação da temática com } \\
\text { o trabalho no campo. }\end{array}$ & $\begin{array}{l}\text { "(...) Ai se essa criança ela não desenvolver, ela não } \\
\text { aprender, ela não vê como é que faz. (...) antigamente os } \\
\text { pais passavam isso pros filhos né? Uma coisa natural, } \\
\text { eles ensinavam a fazer a trança, a fazer o cofo, a fazer o } \\
\text { tapiti né? Fazer a peneira pra penerar a massa, pra } \\
\text { penerar a farinha. Hoje já eles não querem mais né? (...)" }\end{array}$ \\
\hline $\begin{array}{l}\text { Reflexão sobre o papel } \\
\text { da escola como um } \\
\text { espaço de interação } \\
\text { com a cultura } \\
\text { comunitária. }\end{array}$ & $\begin{array}{l}\text { "(...) Eu acredito que os pais não... né? Os pais vão } \\
\text { morrendo, os avós vão sumindo né? E a cultura vai } \\
\text { acabando. E se a gente não desenvolver isso dentro da } \\
\text { sala de aula, isso aí como é que faz os fazeres né (...)" }\end{array}$ \\
\hline $\begin{array}{l}\text { Reflexões sobre relação } \\
\text { professor - estudante, } \\
\text { visualizando interações } \\
\text { discursivas entre esses } \\
\text { sujeitos diante dos } \\
\text { conteúdos abordados. }\end{array}$ & $\begin{array}{l}\text { "(...) Na minha disciplina ... é... o que eu achei importante } \\
\text { no terceiro e quarto bimestre é que são coisas que eu tô } \\
\text { trabalhando que os alunos conhecem, que eu também } \\
\text { assim... eu ... eu tenho uma experiência vivenciada já } \\
\text { antes de sala de aula de... (...) tô trabalhando com uso } \\
\text { de agrotóxico e eu tenho um conhecimento na área de } \\
\text { agrotóxico porque eu trabalhava com lavoura (...)" }\end{array}$ \\
\hline $\begin{array}{l}\text { Emergência de questões } \\
\text { socioambientais ligadas } \\
\text { ao agronegócio e aos } \\
\text { impactos ecológicos }\end{array}$ & $\begin{array}{l}\text { “(...) eu não senti muito a falta desse material porque eu } \\
\text { conhecia a área. Eu trabalhava como... dando } \\
\text { manutenção em lavoura de milho, de soja... trabalhei } \\
\text { muito tempo, uns dez anos mais ou menos. E ai eu trouxe }\end{array}$ \\
\hline
\end{tabular}




\begin{tabular}{|c|c|}
\hline & $\begin{array}{l}\text { sse conhecimento pra sala de aula (...) o uso de } \\
\text { grotóxicos e a legislação que cuida desse agrotóxico } \\
\text {..)" }\end{array}$ \\
\hline $\begin{array}{l}\text { conscientizaç } \\
\text { ambiental diar } \\
\text { tema trabalha } \\
\text { cuidados rela }\end{array}$ & $\begin{array}{l}\text { "(...) trabalhei com os alunos também assim sobre a } \\
\text { questão do respeitar né... porque todo agrotóxico quando } \\
\text { ele é utilizado, ele precisa de um tempo pra que as } \\
\text { pessoas possa andar dentro da lavoura, alguns as vezes } \\
\text { é mais perigoso ou menos perigoso do que outros e os } \\
\text { alunos ... é ... fizemos discussão, fizemos debate, } \\
\text { fizemos resumo de texto. (...)" }\end{array}$ \\
\hline $\begin{array}{l}\text { Estabelecimento de } \\
\text { relação comparativa } \\
\text { entre os diferentes usos } \\
\text { da terra, familiares ou de } \\
\text { grandes negócios, a } \\
\text { partir da perspectiva }\end{array}$ & $\begin{array}{l}\text { "(...) eu gosto de colocar a questão trazendo aquilo como } \\
\text { se fosse um problema nosso. Eu coloco pra eles assim.. } \\
\text { é... as vezes eu tô lá no Mumbuca e lá não tem uso de } \\
\text { agrotóxico, mas eu falo aqui pertinho aqui... tem um } \\
\text { plantio muito grande de lavoura que... acho que uns } \\
\text { quarenta quilômetros pra frente. (...)" }\end{array}$ \\
\hline $\begin{array}{l}\text { Continuidade da } \\
\text { discussão anterior, com } \\
\text { inserção de temática } \\
\text { socioambiental externa } \\
\text { à comunidade, mas } \\
\text { associada aos } \\
\text { problemas ligados aos } \\
\text { usos de recursos }\end{array}$ & $\begin{array}{l}\text { “(...) comentei nas minhas aula até sobre o uso de } \\
\text { minérios que foram utilizados em região de garimpo do } \\
\text { Pará (...) E até os peixes dos rios daquela região passou } \\
\text { muito tempo contaminado por conta de ... do mercúrio } \\
\text { né? na carne e contendo outros produtos, contendo } \\
\text { metal pesado. Então tudo isso é prejudicial pra nós, } \\
\text { mesmo que a gente... que a nossa região ela esteja } \\
\text { protegida ainda porque ninguém utiliza, mas do lado } \\
\text { nosso aqui a gente já tá vendo esse problema (...)" }\end{array}$ \\
\hline
\end{tabular}

\subsection{Estratégias didático-pedagógicas}

"Não há ensino sem pesquisa e pesquisa sem ensino. Esses que-fazeres se encontram um no corpo do outro. Enquanto ensino continuo buscando, reprocurando. Ensino porque busco, porque indaguei, porque indago e me indago. Pesquiso para constatar, constatando, intervenho, intervindo educo e me educo. Pesquisa para conhecer o que ainda não conheço e comunicar ou anunciar a novidade. (...) Pensar certo, do ponto de vista do professor, tanto 
implica o respeito ao senso comum no processo de sua necessária superação quanto o respeito e o estímulo à capacidade criadora do educando" (Freire, P. 1996, p. 32-3).

Os momentos em que os docentes dedicam-se a refletir sobre as principais abordagens didático-pedagógicas utilizadas em suas aulas merecem especial atenção neste texto, pois há especificidades a se considerar. É importante citar, por exemplo, que, na ausência de materiais didático-pedagógicos específicos disponibilizados pela Secretaria de Educação do Tocantins, os professores colocaram-se em posição criativa de observação e sistematização de estratégias de ensino-aprendizagem que dialoguem com o entorno da escola, incluindo a relação da comunidade com suas memórias coletivas, relacionadas ao mundo do trabalho no campo.

No discurso dos professores, é possível perceber uma inquietação inicial em relação à novidade curricular que representou a recente disciplina na rotina escolar. Tal apreensão foi parcialmente diminuída, ao longo do ano letivo, pela percepção de que as fontes primárias de informações para o trato da disciplina poderiam estar presentes na própria comunidade, em suas relações socioprodutivas e pelo acesso a materiais textuais, não específicos, que se encontravam disponíveis no acervo escolar.

Ao compreenderem que a cultura quilombola acompanha o desenvolvimento de práticas sociais, ou que os saberes acompanham os fazeres, e se reconhecerem nessas práticas, os docentes partem do pressuposto de que o que pode ser estudado em sala de aula remete à ideia de usar os aspectos culturais como embasamento primário para o levantamento de informações, indicando uma postura de professorpesquisador sobre a própria comunidade, em suas experiências como moradores desse espaço ou em referenciais externos a ele, como os resultados de pesquisas acadêmicas já realizados utilizando o contexto local como objeto de estudo, mesmo que a continuidade do desafio bibliográfico seja recorrente para a temática.

A partir do reconhecimento de que os códigos e simbologias relativos à cultura quilombola podem ser utilizados para a construção discursiva em torno da disciplina, o núcleo do discurso dos professores, além de considerar o embasamento científico externo das pesquisas acadêmicas, passa a privilegiar os processos internos à 
comunidade, ou seja, a transmissão cultural geracional pela oralidade. À medida que a relação entre cultura, saberes e fazeres torna-se mais clara, ocorre o reconhecimento de que, a despeito da quantidade ou qualidade de materiais préexistentes, há possibilidade de discussão fundamentada nas aprendizagens sociais construídas no seio comunitário, incluindo a interação com as famílias, o trabalho com a terra e o manejo da biodiversidade local, exemplificados pela produção de alimentos ou do artesanato de capim-dourado.

Esse constante fluxo de saberes entre comunidade, escola, professores, estudantes e materiais externos a essa realidade sociocultural apresenta o potencial de tornar o espaço de aprendizagem dialogicamente significativo, pois, à medida que os professores reconhecem similitudes entre as histórias contadas e suas histórias vividas, a necessidade de suporte físico - material torna-se mais difusa e a observação expande-se para as experiências coletivas e individuais que possam contribuir para a elaboração discursiva em torno da disciplina, atribuindo ênfase a experiência humana e colocando o ser humano novamente no centro do debate socioambiental.

Uma das abordagens utilizadas pelos professores em suas pesquisas pedagógicas foi a utilização de entrevistas com pessoas mais velhas da comunidade, refletindo o respeito e a valorização de suas memórias sobre características culturais coletivas, que, na visão dos professores, precisam ser resgatadas. Novamente, entre essas características, há especial atenção aos elementos da biodiversidade local úteis à produção de instrumentos de trabalho no campo.

O fato de a comunidade e suas relações sociais terem sido fonte de informações para o trabalho pedagógico com o novo componente curricular, atribui uma perspectiva ao fazer educativo de "olhar para dentro" da comunidade, dialogando com seus componentes culturais históricos e as diferentes simbologias presentes nas gerações anteriores. De certa maneira, coloca o indivíduo quilombola com suas narrativas e memórias no centro do debate cultural e ambiental e atribui especial destaque à noção de pertencimento dos estudantes e da estrutura escolar a essa coletividade humana que ocupa historicamente esse território.

A caracterização da fonte primária das informações para a disciplina, com a utilização de entrevistas com os moradores antigos da comunidade, reflete ainda uma 
importante discussão sobre educação quilombola-comunitária, que gira em torno dos saberes tradicionais utilizados na construção dos currículos disciplinares, implícitos ou explícitos, escolares. De igual forma, essa prática de entrevista apresenta também a própria prática de transmissão cultural dos quilombolas. Excluídos que foram do sistema formal de ensino, e, portanto, da tradição escrita, as gerações mais antigas desenvolveram, por meio da tradição oral, os vínculos de transmissão de conhecimentos, cultura e história. Por isso a entrevista ou "contação" de causos pelos mais velhos tem um papel importante na vida e na história dos comunitários. Trazer para o espaço escolar esses saberes, configura um movimento de interlocução importante entre esses diferentes espaços, permitindo um diálogo entre o processo de escolarização e as diferentes formações sociais presentes nas relações estabelecidas fora do contexto escolar.

Considera-se, ainda, que posturas dialógicas como as apresentadas pelos docentes podem permitir maior participação dos estudantes nos momentos de diagnóstico e discussão dos conteúdos em sala sobre os elementos pesquisados, valorizando sobremaneira a troca de saberes e experiências sob a ótica dos indivíduos presentes no ambiente de aprendizagem e suas relações pessoais com as temáticas discutidas, mediadores simbólicos dos saberes comunitários no interior da sala de aula.

Faz-se importante considerar, portanto, que os professores tiveram autonomia na busca das informações relacionadas aos temas previstos para serem trabalhados em suas turmas; previsão advinda dos documentos oficiais encaminhados pela Secretaria de Educação para a escola. Essa autonomia e o estímulo à pesquisa traçam uma necessidade de encaminhar os seus próprios mecanismos de certificação das informações alcançadas, colocando-os na condição de intérpretes e pesquisadores de um processo de elaboração curricular que garanta a aprendizagem significativa dos estudantes.

Nos casos mais específicos, em que, por ventura, as temáticas sugeridas não estivessem intimamente ligadas às práticas laborais comunitárias, houve necessidade de pesquisas com aprofundamento teórico-científico mais evidente, como, por exemplo, as temáticas relacionadas à utilização de defensivos agrícolas ou contaminação de rios e desmatamento de matas ciliares, que, no discurso docente, 
não são práticas costumeiras pelos comunitários. Nessas situações-problema, houve necessidade de utilização do discurso científico e parte da experiência dos professores foi direcionada para o uso de textos de cunho acadêmico ou legislações específicas, com menor necessidade de justaposição às vivências comunitárias.

É notório, no discurso coletivo dos professores, que o trabalho com o novo componente curricular foi baseado nos conhecimentos cotidianos comunitários, na necessidade de articulação entre comunidade e escola, e, em casos mais específicos, no discurso científico-acadêmico. A condução das práticas educativas desenvolvidas na escola passou tanto pela experiência coletiva comunitária quanto pela validação, com menor ênfase, em livros, dissertações, manuais, encartes ou outros trabalhos acadêmicos realizados na comunidade, pois estas possuem menor destaque nas suas interlocuções.

A escola, espaço tradicionalmente pensado para promoção da aprendizagem, intersecciona-se com outros espaços da comunidade, sejam eles as casas, os espaços de produção agrícola, as memórias e experiências das pessoas. Assume-se que as múltiplas vozes advindas desses distintos lugares de fala contribuem para uma sistematização do pensamento dos educadores e refletem em sua posição de mediadores essenciais desse fluxo de saberes.

$\mathrm{Na}$ tabela 3, encontram-se trechos das interlocuções dos profissionais associadas a interpretações baseadas no referencial teórico adotado neste trabalho e na subjetividade do pesquisador/analista, permitindo melhor visualização sobre a discussão apresentada neste metatexto temático.

Tabela 3. Quadro analítico do metatexto II - Estratégias didático-pedagógicas.

\begin{tabular}{|c|c|}
\hline $\begin{array}{l}\text { Fortalecimento da } \\
\text { relação com a } \\
\text { comunidade a partir do } \\
\text { trabalho com o novo } \\
\text { componente curricular. }\end{array}$ & $\begin{array}{l}\text { "(...) A gente trabalhou assim, a gente trabalhou dentro } \\
\text { da própria comunidade Mumbuca né. Nós trabalhamos } \\
\text { com o quê? Com as casas, a moradia, a alimentação, } \\
\text { com as coisas que existiam e que hoje não existem, } \\
\text { com entrevistas com as pessoas mais velhas pra nós } \\
\text { resgatar, confirmar o que a gente tava dizendo. (...)" }\end{array}$ \\
\hline
\end{tabular}




\begin{tabular}{|c|c|}
\hline $\begin{array}{l}\text { Relação professor - } \\
\text { aluno estabelecida em } \\
\text { torno da participação } \\
\text { ativa na busca pelas } \\
\text { informações discutidas. }\end{array}$ & $\begin{array}{l}\text { “(...) Junto com os alunos... levava pra sala... e vai } \\
\text { discutir cada coisa, de onde vinha cada objeto, pra que } \\
\text { servia, que objetivo tinha. Por exemplo, o capim- } \\
\text { dourado faziam cestos pra colocar coisas, pra né? } \\
\text { Muito bonito, mas servia de utensílio de casa (...)" }\end{array}$ \\
\hline $\begin{array}{l}\text { Referência aos } \\
\text { trabalhos realizados na } \\
\text { comunidade por Isabel } \\
\text { Schmidt (UnB) e } \\
\text { Rebeca Viana (IB-USP), } \\
\text { abrindo possibilidade } \\
\text { de discussão sobre o } \\
\text { papel das pesquisas } \\
\text { qualitativas } \\
\text { participantes. }\end{array}$ & $\begin{array}{l}\text { “(...) Nós tivemos algum texto... nós pegamos alguns } \\
\text { textos de algumas entrevistas, revistas, livros que foi } \\
\text { feito já em Mumbuca como a de Isabel, como da } \\
\text { Rebeca... Nós pegamos textos pequenos de uma } \\
\text { página, uma citação de alguém que já trabalhou, que } \\
\text { fez pesquisa no Jalapão e que foi comprovado } \\
\text { direitinho. Então assim, é pequeno, não mais de que } \\
\text { cinco, seis linhas não. Era só pra enfatizar. (...)" }\end{array}$ \\
\hline $\begin{array}{l}\text { Reflexões iniciais sobre } \\
\text { a relação entre cultura } \\
\text { e "fazeres" identitários } \\
\text { comunitários. }\end{array}$ & $\begin{array}{l}\text { “(...) Olha, pra nós foi uma surpresa né? Que foi a } \\
\text { primeira vez e a gente caímos lá né? Aí foi assim uma } \\
\text { surpresa assim, porque 'O que é fazeres?' A cultura a } \\
\text { gente ainda vê, não é igual aos fazeres né? A cultura } \\
\text { acompanha o fazeres né? (...)" }\end{array}$ \\
\hline $\begin{array}{l}\text { Referência à } \\
\text { possibilidade de } \\
\text { aprendizagem social, a } \\
\text { partir dos núcleos } \\
\text { familiares, de } \\
\text { elementos da cultura } \\
\text { quilombola associados } \\
\text { à produção alimentar } \\
\text { de subsistência e ao } \\
\text { artesanato de capim- } \\
\text { dourado. }\end{array}$ & $\begin{array}{l}\text { “(...) Porque tem a cultura, às vezes eu tenho a cultura } \\
\text { de plantar mandioca né? De pôr ela de molho na } \\
\text { cacimba no chão né? Então o fazeres é... fazer assim, } \\
\text { ensinar. De que adianta você ter a cultura se você não } \\
\text { sabe fazer, né? Você tem a cultura, as vezes seu pai } \\
\text { sabe fazer a bolsa do capim-dourado. Ai 'não, meu pai } \\
\text { tem a cultura'. Mas, você não faz né? Então você não } \\
\text { vai desenvolver. }\end{array}$ \\
\hline
\end{tabular}




\begin{tabular}{|c|c|}
\hline $\mathbf{a}$ & $\begin{array}{l}\text { "(...) Mas, a gente foi pesquisando às vezes os livros } \\
\text { trabalhados né através do... como é que chama... o } \\
\text { Paulo. (...)" }\end{array}$ \\
\hline $\begin{array}{l}\text { Perspectiva de } \\
\text { introdução das } \\
\text { experiências de } \\
\text { formação pessoal do } \\
\text { educador na práxis } \\
\text { pedagógica em torno }\end{array}$ & $\begin{array}{l}\text { “(...) Fomo montando ali né? Vê como é que fazia e } \\
\text { pesquisando. Às vezes ainda né... pesquisando uma } \\
\text { coisa que às vezes aparecia né? Mas a nossa cultura } \\
\text { era diferente e a gente foi né... Eu falo muito sobre a } \\
\text { cultura, porque meu pai foi criado num ambiente de roça } \\
\text { né... foi criando na roça, então eu já... as tradição e as } \\
\text { cultura... eu já sei um pouco né? (...) }\end{array}$ \\
\hline $\begin{array}{l}\text { A experiência social } \\
\text { dos comunitários } \\
\text { associada às mudanças } \\
\text { socioambientais } \\
\text { temporais ligadas ao } \\
\text { uso dos utensílios } \\
\text { citados, elementos da }\end{array}$ & $\begin{array}{l}\text { “(...) Então nós pegava, por exemplo o Seu Diolino, por } \\
\text { exemplo, nós entrevistamos seu Diolino. (...) Nós } \\
\text { trabalhamos os utensílios que usava antes que não tão } \\
\text { usando nenhum mais, que eles usavam a capa, o cofo, } \\
\text { o tapiti, a panela de barro, a cuia e muitos outros né? } \\
\text { Pedaços de madeira feito né... bacia feito de madeira. } \\
\text { Então assim, hoje muitas coisas ele não usa. (...) a rede } \\
\text { da imbira do buriti, então muitas coisas hoje não existe. } \\
\text { (...)” }\end{array}$ \\
\hline $\begin{array}{l}\text { Reafirmação da } \\
\text { experiência individual, } \\
\text { por meio da } \\
\text { aprendizagem social na } \\
\text { comunidade e sobre a } \\
\text { possibilidades de estas } \\
\text { experiências serem } \\
\text { construtoras dos } \\
\text { objetos de estudo no }\end{array}$ & $\begin{array}{l}\text { “(...) Porque vem uma pessoa lá de São Paulo, vamo... } \\
\text { por exemplo né? que ainda não participou de ver como } \\
\text { é que faz o beju. Não sabe fazer o beju de massa né? } \\
\text { Não sabe às vezes nem como é que faz. A gente já } \\
\text { sabe né? Já sabe muita coisa. Já sabe fazer... trançar } \\
\text { o balaio, sabe fazer o beju de massa, sabe plantar } \\
\text { batata, sabe plantar mandioca, sei plantar o arroz, sei } \\
\text { pilar ele no pilão que é a cultura né...dos povos antigos }\end{array}$ \\
\hline
\end{tabular}




\begin{tabular}{|c|c|}
\hline $\begin{array}{l}\text { omponente curricular, } \\
\text { brindo possibilidade } \\
\text { e o educador refletir } \\
\text { obre sua história }\end{array}$ & $\begin{array}{l}\text { coisas que né? Que às vezes eu falo hoje... eu falo isso } \\
\text { hoje dentro da minha sala de aula né? Falo que meu pai } \\
\text { foi... que ele trabalhava de roça né? Então a gente... eu } \\
\text { participei de tudo né? Como né... meu pai plantava } \\
\text { roça... então hoje eu sei chegar numa roça... sei cavar } \\
\text { uma batata pra plantar (...)" }\end{array}$ \\
\hline $\begin{array}{l}\text { Diferentes usos } \\
\text { nistóricos ligados ao } \\
\text { artesanato de capim- } \\
\text { dourado, desde } \\
\text { associações } \\
\text { utilitaristas até aquelas } \\
\text { igadas à } \\
\text { comercialização dos }\end{array}$ & $\begin{array}{l}\text { “(..) Era chapéu.. já conhecia a trança... de utensílio } \\
\text { doméstico mesmo pra labutar, fazia uma bolsinha pra } \\
\text { colocar coisinha dentro. (...) Hoje ele tem outra função } \\
\text { de o pessoal chegar a comprar, nós fazer e ter um lucro. } \\
\text { Mas nunca deixamos de dizer que aquilo era uma coisa } \\
\text { nossa, que é cultura entendeu? (...) E a gente nunca } \\
\text { deixa de dizer que isso aqui é uma cultura que vem, } \\
\text { mas naquele tempo ele servia mesmo era pra isso. (...)” }\end{array}$ \\
\hline $\begin{array}{l}\text { Associação das } \\
\text { temáticas ligadas à } \\
\text { disciplina com } \\
\text { questões associadas às } \\
\text { diferentes cadeias } \\
\text { produtivas presentes } \\
\text { no Cerrado brasileiro, e } \\
\text { os impactos } \\
\text { socioambientais }\end{array}$ & $\begin{array}{l}\text { “(...) Eu... eu peguei da internet... peguei um material... } \\
\text { baixei a legislação que trata do uso de agrotóxicos. } \\
\text { Baixei alguns artigos também que falam sobre... não } \\
\text { lembro o nome do lugar... mas foi feito aqui um trabalho } \\
\text { com os alunos da Universidade Fluminense. (...) Eu } \\
\text { encontrei esse material também, levei pra eles. } \\
\text { Distribuí. Eles fizeram a leitura. Eles fizeram } \\
\text { comentários. Busquei pra usar na sala de aula. E não é } \\
\text { um material que tava presente na escola. (...)” }\end{array}$ \\
\hline
\end{tabular}

\subsection{Questões socioambientais}

"Ao reconhecer que, precisamente porque nos tornamos seres capazes de observar, de comparar, de avaliar, de escolher, de decidir, de intervir, de romper, de optar, nos fizemos seres éticos e se abriu para nós a probabilidade de transgredir a ética, jamais poderia aceitar a transgressão como um direito mas como uma possibilidade. Possibilidade contra que devemos lutar e não diante da qual cruzar os braços" (Freire, P. 1996, p. 112-13). 
Os caminhos reflexivos dos professores, quando tratam sobre as temáticas socioambientais que possam estar articuladas aos assuntos trabalhados na nova disciplina, apresentam-se de forma homogênea no encadeamento lógico realizado durante as entrevistas, pois refletem principalmente sobre os usos de elementos da natureza que os comunitários estabeleceram ao longo da história de ocupação do território, em uma visão utilitarista do meio ambiente. No entanto, tal visão não está desassociada da formação cultural deste povo, estabelecida com base na aprendizagem fundamentada nos serviços ambientais que a biodiversidade vegetal pôde garantir e estimular durante a permanência nos locais ocupados.

Percebe-se, em suas interlocuções, uma perspectiva protecionista do meio ambiente, evidenciada na natureza da abordagem dos conteúdos da disciplina, levando em consideração que a relação ser humano/meio ambiente estabelecida pelos professores, possui, no fator trabalho, importante elo com os elementos da biodiversidade local, ressaltando-se uma preocupação com as possibilidades de degradação ambiental possivelmente causadas pelo consumo humano e as diferentes formas de apropriação da natureza.

Nesse sentido, durante a história da comunidade, esses sujeitos passam a atribuir um valor simbólico intrínseco aos elementos da biodiversidade manejados, incluindo pensamentos e ações relacionados à conservação cultural e ambiental, associados às práticas de manejo. Dessa forma, a importância da conservação da biodiversidade, para além da perspectiva motivada por princípios ecológicos, tem ênfase na relação histórica, cultural e afetiva estabelecida pela comunidade com a natureza.

A experiência humana constituída por meio do trabalho para subsistência consolidou o aprendizado que os fundadores da comunidade estabeleceram e se constituiu em saberes sociais comunitários, que estão sendo ensinados na escola, no trato da disciplina, sistematizados pelos professores para o contexto curricular, demonstrando preocupação com a conservação de antigas práticas culturais sobre a natureza e posicionando a coletividade como elemento importante no estabelecimento das estratégias de conservação nesse território. Tal inferência é possível de ser compreendida pela presença constante de citações ao espaço geográfico biorregional 
que circunda a comunidade e sobre as memórias coletivas a respeito de determinados espaços naturais nessa área.

Esse "olhar de fora", utilitarista e recursista de garantia de sobrevivência que os professores possuem sobre os serviços ambientais, associa-se com a perspectiva de cuidado nas atividades exploratórias da comunidade, agricultura e extrativismo. Indicando, também, que há uma interdependência nessa interação, pois os serviços ambientais que o Cerrado provê e as práticas de subsistência humana retroalimentam-se, produzindo os elementos da cultura quilombola que repercutem, por sua vez, nas memórias coletivas, nas representações sociais e nas práticas laborais ligadas ao abastecimento alimentar, artístico, comercial e econômico da população.

O enfoque utilitarista e recursista do ambiente é acompanhado de uma narrativa memorialística pelos docentes, em que a concepção sobre a relação natureza/ser humano não é puramente ecológica, pois, na história de ocupação do território pela comunidade, em suas vivências coletivas, promove-se a cultura local e, ciclicamente, promove-se também um processo de modificação do meio ambiente pelos diferentes métodos de manejo, coleta e extrativismo de espécies vegetais, permitindo que a transmissão oral da cultura quilombola recrie as percepções sobre o ambiente natural.

A descrição de práticas extrativistas, produtivas e de uso racional dos recursos ambientais pelos docentes reflete uma preocupação de que os saberes oficializados na disciplina associam-se à conservação sócio ambiental, aproximando-se de concepções conservacionistas/recursistas da natureza, mas também revelam um caminho para se discutir, pedagogicamente, sobre a sustentabilidade das atividades produtivas praticadas pelos comunitários, permitindo que as atividades educativas planejadas pelos docentes possam integrar conhecimentos ancestrais, práticos e ecológicos, motivados por uma perspectiva identitária que agregue relações de afeto com o conhecimento local sobre a biodiversidade.

No momento em que os professores intencionam explorar os saberes quilombolas associando-os às questões sociais e ambientais locais, percebe-se um processo de contextualização das estratégias discursivas que aproximam a instituição escolar das práticas sociais comunitárias, permitindo melhor compreensão pelos 
estudantes sobre os temas sistematizados e trabalhados em sala de aula, falando a mesma língua e visualizando uma perspectiva de trabalho que discuta as aproximações e divergências entre o praticado na comunidade e fora dela, em um contexto regional mais amplo.

É importante, portanto, mencionar que o pensamento dos docentes sobre as questões socioambientais ligadas à disciplina não estão circunscritos somente às atividades praticadas pelos comunitários, mas também refletem sobre as externalidades ligadas às diferentes cadeias produtivas presentes no Cerrado brasileiro, em um estabelecimento comparativo sobre os usos da natureza e os impactos socioambientais promovidos em escalas distintas, por exemplo, pela agricultura monocultora e pela agricultura familiar e comunitária, possibilitando uma abordagem política para o trato da questão.

É interessante perceber que os aspectos culturais cotidianos, locais ou regionais, incluindo questões ligadas ao desmatamento pela atividade monocultora no Cerrado, podem ser identificados nas intenções pedagógicas dos professores, associando os saberes comunitários ligados aos usos da terra com uma preocupação sobre a sustentabilidade de suas próprias práticas produtivas. $\mathrm{Na}$ sala de aula, os saberes sociais comunitários, pessoais, de professores e estudantes, presentes nas vozes da experiência e da formação profissional desses sujeitos, encontram-se, produzindo um espaço de troca e elaboração de um currículo implícito que dialoga com problemáticas socioambientais ligadas ao Cerrado, tais como o manejo de fogo e o desmatamento.

Por fim, há uma expectativa de mudança comportamental evidenciada na abordagem de aprendizagem dialógica entre professores, estudantes e as vozes de outros sujeitos, proprietários de roçados e áreas com nascentes de rios. Nos momentos de atividades de campo, os professores almejam criar um cenário de redescoberta do cotidiano pelos seus estudantes, fomentando discussões sobre a história da comunidade e de seus moradores mais antigos, as estratégias de ocupação do território para moradia ou construção de roçados, e as diversas cadeias produtivas, como artesanato, diferentes manejos de biodiversidade vegetal, produção agrícola e outros usos de serviços ambientais apreendidos no contexto local. 
Há, dessa forma, a presença de uma multiplicidade de vozes no discurso dos professores, representadas pelos saberes ancestrais da comunidade, os saberes científicos e acadêmicos dos professores e as externalidades sociais que posicionam as interlocuções dos professores como mediadoras entre os contextos locais e regionais. Embasado nas falas dos educadores sobre as cadeias produtivas locais/comunitárias e do agronegócio da região, percebe-se um reforço à visão interdisciplinar da área associada à disciplina, visto que as diferentes cosmovisões sobre estes processos produtivos são abordadas, incluindo objetos, escalas, métodos e possíveis impactos diferenciados dessas formas de produção ao ambiente natural, evidenciando uma expectativa de aprendizagem que dialogue com alguma mudança social/cultural nos estudantes diante dos problemas apresentados, e avaliando a necessidade de modificar as práticas produtivas que possam ser consideradas insustentáveis.

$\mathrm{Na}$ tabela 4, encontram-se trechos das interlocuções dos profissionais associadas a interpretações baseadas no referencial teórico adotado neste trabalho e na subjetividade do pesquisador/analista, permitindo melhor visualização sobre a discussão apresentada neste metatexto temático.

Tabela 4. Quadro analítico do metatexto III - Questões Socioambientais.

\begin{tabular}{|c|c|}
\hline $\begin{array}{l}\text { Associação entre } \\
\text { elementos da } \\
\text { biodiversidade do } \\
\text { Cerrado e o cotidiano } \\
\text { quilombola ligado à } \\
\text { alimentação, moradia e } \\
\text { saúde. }\end{array}$ & $\begin{array}{l}\text { “(...) O que eu percebo é que os nossos antepassados } \\
\text { viveu por causa da natureza, e contribuiu o pequi, o } \\
\text { buriti. Imagina se não tivesse o buriti, se não tivesse o } \\
\text { coco piaçava, se eles não soubessem manejar prafazer } \\
\text { suas casas, o buriti pra pegar o óleo pra sarar as } \\
\text { feridas, o pequi pra se alimentar e o óleo. (...)" }\end{array}$ \\
\hline $\begin{array}{l}\text { Valorização dos } \\
\text { elementos da } \\
\text { biodiversidade como }\end{array}$ & $\begin{array}{l}\text { “(...) Como é que nós ia sobreviver sem o pequi, sem o } \\
\text { buriti, sem a mangaba, sem a bacaba, sem essas } \\
\text { árvores, tudo assim, isso tudo faz parte de nós. (...)” }\end{array}$ \\
\hline
\end{tabular}




\begin{tabular}{|c|c|}
\hline itónin & \\
\hline $\begin{array}{l}\text { Estreitamento da } \\
\text { ligação entre o par } \\
\text { natureza x cultura, } \\
\text { implicando uma } \\
\text { postura dialógica não } \\
\text { fragmentária. }\end{array}$ & $\begin{array}{l}\text { "(...) Quando você resgata ela, que você estuda ela, que } \\
\text { você vê, você fala que a natureza anda lado a lado com } \\
\text { o ser humano, se não existisse a natureza não existia } \\
\text { essa cultura, não existia esse povo. Tudo era o buriti, } \\
\text { tudo era o capim-dourado, tudo era a natureza. (...)" }\end{array}$ \\
\hline $\begin{array}{l}\text { Preocupação com a } \\
\text { conservação do } \\
\text { Cerrado, por meio dos } \\
\text { sistemas de manejo } \\
\text { produtivo } \\
\text { desenvolvidos pelos } \\
\text { comunitários ao longo } \\
\text { do tempo. }\end{array}$ & $\begin{array}{l}\text { “(...) O sistema de manejo da... do solo, nós não teria } \\
\text { alimento pra sobreviver e nem também o ambiente, já } \\
\text { que tinha destruído tudo porque mais de duzentos anos } \\
\text { derribando roça, uma roça aqui outra aqui, não. Então } \\
\text { nós tinha cuidado, nós tinha um lugar mas é um lugar } \\
\text { que a gente há quarenta anos e muitos lugares ficou } \\
\text { sem desmatar, ficou (i)leso, por que? Por que nós } \\
\text { manejamos aquele lugar e é um lugar pequeno, mas } \\
\text { bem quadrejadinho, bem planejado que é pra não } \\
\text { destruir, por exemplo, se aqui nós aqui essa quantidade } \\
\text { de pessoas morando em Mumbuca derribando roça, } \\
\text { tinha um pau ali ao redor? (...)” }\end{array}$ \\
\hline $\begin{array}{l}\text { Descrição de práticas } \\
\text { conservacionistas } \\
\text { ligadas ao manejo de } \\
\text { buriti e ao manejo de } \\
\text { fogo no Cerrado, a } \\
\text { partir dos saberes } \\
\text { ancestrais } \\
\text { comunitários. }\end{array}$ & $\begin{array}{l}\text { “(...) Tinha que ter cuidado, cuidado com o pé de pequi, } \\
\text { cuidado com o pé de buriti, tem um cuidado. Então a } \\
\text { gente entrevista com esse pessoal de idade, sempre } \\
\text { eles falam que tinha que ter cuidado com o buriti, } \\
\text { cuidado com tirar o olho do buriti pra se trabalhar, o } \\
\text { cuidado pra tirar a palha do buriti que não morre né? O } \\
\text { cuidado com o fogo, com o manejo. (...)" }\end{array}$ \\
\hline $\begin{array}{l}\text { Evidência sobre a } \\
\text { aprendizagem social } \\
\text { ligada a práticas de }\end{array}$ & $\begin{array}{l}\text { “(...) Aí eu até perguntei assim 'Porque que naquele } \\
\text { tempo não queimavam?' Mas, não era nós, era os } \\
\text { fazendeiros, era quem tinha gado. (...) Nós tinha o maior }\end{array}$ \\
\hline
\end{tabular}




\begin{tabular}{l} 
manejo de fogo e \\
desmatamento pela \\
comunidade, \\
articuladas a uma \\
dimensão regional e \\
política, ligada às \\
cadeias produtivas do \\
Cerrado. \\
\hline Descrição de práticas \\
conservacionistas \\
ligadas à produtividade \\
agrícola e seus \\
impactos sobre os rios \\
e nascentes na região.
\end{tabular}

cuidado, o maior zelo de proteger as cabeceiras, por exemplo. As cabeceiras tinha uma época que não podia ser queimada. (...) Digo, por que? 'Não, porque meu pai falava que as cabeceiras não podem ser queimada, todos os brejinho secou, mas o meu não secou, porque eu não queimei a cabeceira, meu pai falou que não pode queimar a cabeceira'. Então tinha esse conhecimento (...)"

“(...) A gente já leva pra sala de aula direitinho, que tem que ter cuidado com isso. O esgoto, a água que corre, por exemplo, a enxurrada, a gente tem que fazer os negócio praquela água não ir pro brejo por que seca. Porque tem um brejo lá de anos, que nós fomos lá, mostramos, já secou, a água aterrou porquê? Porque a pessoa não fez mais o rego. Antigamente, o rego... a água não desce da fonte direto pro brejo, tinha vários rego, várias lombadas como dizia o povo. (...)"

\section{Preocupação}

evidenciada no escopo

da disciplina sobre sua

articulação com

temáticas

socioambientais

ligadas à conservação. “(...) Essa matéria nova... como ela surgiu... ela se relaciona assim ao meio ambiente de proteger, porque a gente vai participar né? Como a gente vai lidar com a natureza, pra não prejudicar ela, entendeu? Que não venha trazer danos a ela, então a gente vive no meio dela, vive dela e que não venha prejudicar, entendeu? $(\ldots) "$

Diferentes usos da
biodiversidade local,
praticadas por meio da
agricultura de
subsistência e da

“(...) Que é aproveitar o que ela nos oferece. Que muitas vezes não é só o tudo plantar né? Tem lá na natureza, por acaso, o buriti né? O que a gente usa da fruta que a gente alimenta né? Da palha que a gente extrai que faz tanta coisa. Faz viola de vereda né? Faz... da tala o tapiti pra secar a massa. (...) Da palha faz a vassoura 


\begin{tabular}{|c|c|}
\hline $\begin{array}{l}\text { produtos de } \\
\text { vegetal. }\end{array}$ & $\begin{array}{l}\text { né? Que a gente sabe fazer a vassoura né? Se for pra } \\
\text { mim fazer uma vassoura de buriti da palha eu sei fazer. } \\
\text { A seda que extrai pra costurar o capim. Da palha faz o } \\
\text { cofo né... pra guardar. Ali no mato as vezes você acha } \\
\text { uma fruta lá, não tem a vasilha eu sei fazer o cofo e } \\
\text { trazer. (...)" }\end{array}$ \\
\hline $\begin{array}{l}\text { Evidência de prática } \\
\text { pedagógica promotora } \\
\text { de conscientização } \\
\text { ambiental coletiva entre } \\
\text { os estudantes, } \\
\text { principalmente } \\
\text { relacionada à } \\
\text { problemática ligada ao } \\
\text { desmatamento. }\end{array}$ & $\begin{array}{l}\text { "(...) Eu discuto isso dentro da sala. Eu discuto isso com } \\
\text { meus alunos. O quê que a gente tem que fazer? O quê } \\
\text { que a gente não pode fazer? Saber falar dessa... essa } \\
\text { língua é sempre dentro da sala de aula. Sempre eu tô } \\
\text { lidando, falando né? O que a gente pode fazer. (...) } \\
\text { Cortar pra quê se não vai ter utilidade nenhuma né? } \\
(\ldots) \text { " }\end{array}$ \\
\hline $\begin{array}{l}\text { Perspectiva didática } \\
\text { associativa entre as } \\
\text { temáticas abordadas } \\
\text { em sala que possam } \\
\text { estar ligadas aos } \\
\text { saberes } \\
\text { socioambientais e aos } \\
\text { saberes identitários } \\
\text { comunitários. }\end{array}$ & $\begin{array}{l}\text { “(...) Sim, eu acredito que sim porque uma coisa tá... é } \\
\text { atrelada a outra né? Não dá pra trabalhar } \\
\text { separadamente essas duas disciplinas ai. Pela } \\
\text { importância dela é... uma depende da outra, no dia a } \\
\text { dia da sala de aula você vê que é necessário é... tá } \\
\text { sempre focando nos dois assuntos. (...)” }\end{array}$ \\
\hline $\begin{array}{l}\text { Evidência de trabalho } \\
\text { colaborativo entre os } \\
\text { docentes e a } \\
\text { comunidade, } \\
\text { possibilitando o } \\
\text { encontro de vozes na }\end{array}$ & $\begin{array}{l}\text { “(...) Fizemos uma abordagem... fizemos uma visita lá } \\
\text { na região que tinha rio né? Inclusive os outros } \\
\text { professores também foram, a professora Márcia lá... } \\
\text { Era rio e ela falou que ela foi criada lá. Falou 'A gente } \\
\text { pegava peixe aqui... pegava traíra aqui e hoje não tem } \\
\text { mais'. Eu falei 'mas tudo isso... o rio ele não seca, o } \\
\text { homem que acaba com ele, que acaba matando ele. }\end{array}$ \\
\hline
\end{tabular}




\begin{tabular}{|c|c|}
\hline $\begin{array}{l}\text { elaboração discursiva } \\
\text { da disciplina. }\end{array}$ & $\begin{array}{l}\text { Então, isso é tudo questão de educação pras pessoas } \\
\text { né? (...)" }\end{array}$ \\
\hline $\begin{array}{l}\text { Nova interlocução } \\
\text { evidenciando } \\
\text { preocupações ligadas } \\
\text { ao desmatamento, à } \\
\text { produção agrícola e } \\
\text { preservação de matas } \\
\text { ciliares e nascentes. }\end{array}$ & $\begin{array}{l}\text { “(...) Onde não é pra desmatar, as pessoas desmatam. } \\
\text { Onde não é pra plantar, elas acabam plantando. Às } \\
\text { vezes... muitas vezes é porque não conhece. Mas, hoje } \\
\text { a informação tá muito acessível. Todo mundo sabe que } \\
\text { não pode derrubar próximo de nascente, mas as } \\
\text { pessoas acabam fazendo. (...)" }\end{array}$ \\
\hline
\end{tabular}

\title{
1.4. Desafios e conquistas
}

\begin{abstract}
"O pensar certo sabe, por exemplo, que não é a partir dele como um dado, que se conforma a prática docente crítica, mas sabe também que sem ele não se funda aquela. A prática docente crítica, implicante do pensar certo, envolve o movimento dinâmico, dialético, entre o fazer e o pensar sobre o fazer. (...) Por isso é que, na formação permanente dos professores, o momento fundamental é o da reflexão crítica sobre a prática. É pensando criticamente a prática de hoje ou de ontem que se pode melhorar a próxima prática" (Freire, P. 1996, p. 42-3).
\end{abstract}

Há certa concordância apresentada nas interlocuções dos docentes sobre os principais desafios travados e as conquistas pedagógicas alcançadas no trato do novo componente curricular, durante o ano letivo de 2017. Os desafios apresentados pelos professores repousam principalmente na ausência de materiais didáticos específicos para trabalhar a disciplina e a necessidade de contextualização, dada a territorialização que a escola possui, dos conteúdos trabalhados ao cotidiano quilombola-comunitário.

Nesse quesito, a comunidade, apesar de ter sido objeto de pesquisas anteriores com certa frequência, ainda assim, carece de dados acadêmicos sobre si mesma. Isso se deve ao fato de que tais pesquisas nem sempre levaram em conta, em seus procedimentos, a produção conjunta ou a coprodução de conhecimentos ou mesmo o retorno dos resultados aos comunitários, refletindo-se na falta aos professores, de referenciais mais formalizados sobre a própria comunidade. Tal falta, pode não residir na ausência de pesquisadores e instituições acadêmicas que usam 
a comunidade como suporte de apoio ou investigação, mas na abordagem metodológica utilizada durante as pesquisas.

Ressaltamos aqui a importância da utilização de metodologias de pesquisa que apresentem uma abordagem cooperativa e colaborativa, que compreendam as necessidades desses sujeitos diante dos temas investigados, incluindo a produção de material didático para uso escolar formal, articulando os produtos das pesquisas com os debates internos da comunidade, e oportunizando a continuidade de uma perspectiva de diálogo de vozes, acadêmicas e comunitárias, em um processo de contextualização educativa.

Os desafios associados à falta de material didático disponibilizado pela Secretaria de Educação foram encarados como oportunidade de estabelecer um trabalho pedagógico propositivo na disciplina; olhar as relações sociais estabelecidas no interior da comunidade, entrevistar moradores mais antigos como fonte primária de informações para a transposição didática e realizar pesquisas bibliográficas, quando os temas tratados indicavam a necessidade de uma abordagem menos interligada às práticas comunitárias. Essa posição dos docentes reflete uma perspectiva de ensinoaprendizagem que dialoga com a tentativa de integração escola-comunidade, não apresentando a escola como detentora de todos os saberes a serem ensinados para a juventude, mas atribuindo importância à desobstrução dos muros escolares para a entrada das vozes comunitárias que discursam sobre a história e cultura quilombolas.

Esse movimento de busca das fontes primárias no diálogo com a comunidade e em bibliografias especializadas posiciona os docentes como mediadores entre os saberes quilombolas-comunitários e os saberes oficializados pela nova disciplina na escola, diante de um diagnóstico que é planejado considerando as necessidades dos estudantes, pois permite uma relação ensino-aprendizagem articulada com as experiências vivenciadas pelo mesmos em seu cotidiano familiar e social, contextualizado com as suas realidades locais.

Essa seleção crítica de conteúdos pode promover, nos estudantes, sujeitosalvo da aprendizagem contextualizada, a compreensão sobre a importância dos códigos culturais assentados historicamente entre os seus pares comunitários, e sob outro ponto de vista, oportuniza, para a escola a oficialização da função pesquisadora dos docentes sobre os conteúdos da aprendizagem social comunitária. 
É nesse sentido que temas importantes ligados a questões socioambientais são citados pelos docentes como saberes quilombolas, tais como roçado de esgoto, adubação orgânica e cadeia produtiva alimentícia da comunidade, a relação do povo com o manejo do fogo e o desmatamento da região, consumo consciente de recursos hídricos e destino adequado de resíduos sólidos. Portanto, as dificuldades práticas no trabalho com o novo componente curricular apontaram o caminho para resolução que representa o diálogo entre os diferentes saberes da comunidade, fazeres relacionados a questões ambientais com ênfase em práticas agrícolas e o estabelecimento de uma preocupação com a preservação dessas práticas socialmente construídas.

Esse cenário torna-se motivador de uma postura dialógica em sala de aula, diante das experiências relatadas pelos estudantes, o que indica que as experiências individuais sobre os temas trabalhados assumem importância nesse contexto de aprendizagem em que os sujeitos envolvidos com a discussão, docentes-estudantes, levam para a interação discursiva suas dúvidas, questionamentos, experiências, investigações e certezas, permitindo um fluxo interdiscursivo, mediado pela pesquisa docente entre as interlocuções presentes na comunidade propriamente dita e as apresentadas pelos estudantes na interação escolar.

A presença das vozes dos estudantes e dos demais comunitários na interação da sala de aula abre-se, portanto, para uma estratégia de contextualização dos saberes, que, aliada a um processo educativo aparentemente dialógico, permite enfatizar um enfoque participativo de compartilhamento de conhecimentos entre professores, estudantes e comunitários.

A respeito das conquistas pedagógicas sentidas pelos docentes ao longo do ano letivo, há uma ênfase nos processos de valorização da identidade comunitáriaquilombola e na elaboração da teia interdiscursiva entre estudantes, professores e comunitários mediada pela função integradora, oportunizada pelo componente curricular. $\mathrm{Na}$ avaliação dos docentes, em alguma medida, a oralidade, como característica marcante da comunidade e de outros povos tradicionais, precisa ser fortalecida, e a disciplina tem auxiliado na manutenção desse fluxo de informações entre as diferentes gerações, a partir da ação direta na sala de aula.

Outro aspecto que pode ser considerado como conquista pedagógica relatado no discurso dos docentes, versa sobre a participação dos estudantes na interação 
discursiva na sala de aula, de forma horizontal, quando sentem alguma inclinação sobre o tema objeto de estudo, demonstrando uma possibilidade de troca de saberes entre os sujeitos, tornando a sala de aula um espaço de aprendizagem colaborativa, democrática, havendo nos sujeitos de aprendizagem a oportunidade de compartilhamento de suas vivências e experiências diante dos objetos e das problematizações docentes, pois a contextualização dos saberes atinge os estudantes em sua cotidianidade.

Por fim, um terceiro aspecto considerado como conquista pedagógica diz respeito diretamente ao trabalho dos docentes, que se sentiram impulsionados em pesquisar os conteúdos associados à disciplina para satisfazer as necessidades de trabalho previstas. A postura de sujeito-pesquisador fomentada pela ausência de materiais didáticos levou, inclusive, a uma reflexão sobre a elaboração desse referencial, guardando ampla associação com as discussões realizadas anteriormente e a elaboração de metodologias de pesquisas acadêmicas em uma perspectiva colaborativa e de empoderamento profissional e pessoal. Na visão dos docentes, a participação da comunidade e dos diferentes sujeitos envolvidos com a disciplina devem ser não somente consideradas, mas sua participação efetiva é necessária para a elaboração de qualquer material, visto que o processo de contextualização dos temas, de forma participativa, garante que a instrumentalização posterior seja útil às reais necessidades educativas, nos diferentes contextos de aplicação.

Nesse sentido, a ausência de material pedagógico de apoio relatada pelos docentes levou ao estabelecimento de uma postura crítica em relação à forma como a nova disciplina foi implementada na estrutura curricular da escola. Ao mesmo tempo que houve a tendência de busca de fontes primárias de informações na comunidade e de referências bibliográficas específicas, quando os temas previstos para trabalho assim demandavam, houve um esforço para não desconsiderar o papel das estruturas políticas de poder associadas à implantação e elaboração de material para a disciplina, incluindo uma crítica às posições hierárquicas estabelecidas entre a Secretaria de Educação do Tocantins e a escola comunitária, assim como entre os docentes da escola, em sua função pesquisadora, e sujeitos/pesquisadores externos à comunidade que possam participar desse processo de produção. 
$\mathrm{Na}$ tabela 5, encontram-se trechos das interlocuções dos profissionais associadas a interpretações baseadas no referencial teórico adotado neste trabalho e na subjetividade do pesquisador/analista, permitindo melhor visualização sobre a discussão apresentada neste metatexto temático.

Tabela 5. Quadro analítico do metatexto IV - Desafios e Conquistas.

\begin{tabular}{|c|c|}
\hline $\begin{array}{l}\text { Associação da } \\
\text { ausência de material } \\
\text { didático específico com } \\
\text { as pesquisas } \\
\text { acadêmicas realizadas } \\
\text { na comunidade e com a } \\
\text { contextualização dos } \\
\text { saberes locais. }\end{array}$ & $\begin{array}{l}\text { “(...) O maior desafio porque é uma matéria nova e é um } \\
\text { conhecimento que quase ninguém teve valor assim... é } \\
\text { em pesquisa, em material didático. Então assim, a } \\
\text { gente teve que criar e adaptar à realidade. Às vezes nós } \\
\text { tinha uns conteúdos, algumas pesquisas de alguns } \\
\text { pesquisadores, mas nós tivemos que adequar isso à } \\
\text { nossa realidade, a linguagem real da comunidade né? } \\
\text { (...)” }\end{array}$ \\
\hline $\begin{array}{l}\text { Apresentação da } \\
\text { postura de pesquisa } \\
\text { pelos educadores em } \\
\text { uma abordagem } \\
\text { participativa com a } \\
\text { comunidade. }\end{array}$ & $\begin{array}{l}\text { “(...) Às vezes tem algumas pesquisas que tem um... } \\
\text { linguajar que não dá pras crianças aqui compreender. } \\
\text { Então a gente teve que adaptar, pegar esse trabalho e } \\
\text { adaptar à realidade do aluno pra gente tá trabalhando e } \\
\text { o maior desafio foi a falta de material de conteúdo, } \\
\text { então a gente teve que criar o nosso conteúdo né? Criar } \\
\text { o nosso conteúdo, fazer a nossa pesquisa e usar as } \\
\text { pessoas mais velhas como referência. (...)” }\end{array}$ \\
\hline $\begin{array}{l}\text { Preocupação em } \\
\text { discutir conteúdos } \\
\text { contextualizados com a } \\
\text { realidade vivenciada } \\
\text { pelos estudantes. }\end{array}$ & $\begin{array}{l}\text { “(...) Usar as pessoas mais velha, usar o que a gente } \\
\text { tinha de... elemento, de fonte mesmo real. Então, a } \\
\text { gente teve esse trabalho de juntar todas essas } \\
\text { informação e colocar no papel e fazer nosso plano de } \\
\text { aula segundo a necessidade do aluno, diagnóstico do } \\
\text { aluno e segundo a realidade local aqui (....." }\end{array}$ \\
\hline $\begin{array}{l}\text { Estímulo à participação } \\
\text { do estudantes diante } \\
\text { do conhecimento }\end{array}$ & $\begin{array}{l}\text { “(...) A principal conquista foi resgatar e mostrar pros } \\
\text { alunos, principalmente os da primeira fase, como era } \\
\text { nosso antepassado, como é que foi criado aqui, como }\end{array}$ \\
\hline
\end{tabular}




\begin{tabular}{|c|c|}
\hline & $\begin{array}{l}\text { é que era mesmo eles né? Sem alfabetização ao contar } \\
\text { a história e comparar como é que era antigamente. Eles } \\
\text { abre assim um leque assim na mente deles de perceber } \\
\text { e deles querer buscar né? (...)" }\end{array}$ \\
\hline $\begin{array}{l}\text { Identificação da função } \\
\text { social da escola pública } \\
\text { com territorialidade } \\
\text { quilombola e } \\
\text { associação com } \\
\text { saberes tradicionais } \\
\text { relacionados a práticas } \\
\text { produtivas. }\end{array}$ & $\begin{array}{l}\text { “(..) No princípio foi uma grande dificuldade assim, } \\
\text { porque quando surgiu essa matéria dos Saberes e } \\
\text { Fazeres e a gente ficou... não tinha no currículo o quê } \\
\text { que era pra gente executar nos bimestres. A gente foi } \\
\text { procurar... saber o quê que que era que a gente... é... } \\
\text { ampliar na comunidade, né? Por ser uma escola } \\
\text { quilombola aí a gente fomos buscar essas atividades } \\
\text { com os fazeres, fomos desenvolvendo, no caso nós } \\
\text { trabalhamos a roça de toco né (...) trabalhamos é... } \\
\text { sobre a roça de esgoto né, como plantá. E no meio } \\
\text { dessas atividades aí a gente aplicava às vezes uns } \\
\text { saberes né? (...)” }\end{array}$ \\
\hline $\begin{array}{l}\text { Preocupação com a } \\
\text { formação dos } \\
\text { estudantes para a } \\
\text { cidadania associadas } \\
\text { ao ambiente em que } \\
\text { vivem. }\end{array}$ & $\begin{array}{l}\text { “...) Às vezes eles iam fazendo, mas não sabiam o quê } \\
\text { que podia acontecer. O fazeres que podia prejudicar } \\
\text { alguma coisa, mas o hoje o Fazeres que a gente tá é... } \\
\text { buscando essa cultura antepassado por causa que de } \\
\text { tanto fazer as coisas tão sendo né... indo de mal a pior, } \\
\text { então a gente tem que desenvolver uma arte e um } \\
\text { trabalho que seja uma cultura né permanente e que não } \\
\text { seja... que possa vir amanhã no futuro dessas crianças, } \\
\text { que não seja prejudicável né? Que elas desenvolvam a } \\
\text { cultura delas no ambiente que vivem (...)” }\end{array}$ \\
\hline $\begin{array}{l}\text { Associação direta dos } \\
\text { saberes quilombolas } \\
\text { com questões práticas } \\
\text { socioambientais } \\
\text { ligadas ao Cerrado. }\end{array}$ & $\begin{array}{l}\text { “(...) Tem muitos Fazeres que a gente tá desenvolvendo } \\
\text { né? Tem a queimada... o fogo né? A queimada } \\
\text { controlada e que não é controlada né? Desmatamento } \\
\text { também. Ai então são muitos Fazeres que a gente vai } \\
\text { desenvolvendo né? (...) o adubo orgânico né? E pra }\end{array}$ \\
\hline
\end{tabular}




\begin{tabular}{|c|c|}
\hline & $\begin{array}{l}\text { gente tá sempre mudando né alguma coisa assim. Mas, } \\
\text { o que a gente mais busca mesmo, são coisas mesmo } \\
\text { da... que envolvem a natureza, a gente quer trabalhar } \\
\text { dessa forma né? (...)" }\end{array}$ \\
\hline $\begin{array}{l}\text { Indicativo de relação } \\
\text { dialógica entre } \\
\text { educador x educandos, } \\
\text { promotora de } \\
\text { aprendizagem ativa. }\end{array}$ & $\begin{array}{l}\text { “(..) A gente, pelo menos no ano passado, a gente } \\
\text { trabalhou... nós tivemos, eu senti assim que as coisas } \\
\text { que eles não sabiam né o significado, não sabiam, mas } \\
\text { outros já sabia. Então a gente viu que a criança ela foi } \\
\text { mantendo muito... foi muito fácil assim pra eles } \\
\text { pegarem né? Eles acharam muita facilidade nessa } \\
\text { matéria que a gente desenvolveu nesse trabalho e a } \\
\text { gente também aprende também né? Junto com elas a } \\
\text { gente aprende também, porque quando a gente tá } \\
\text { relatando sobre uma matéria ou o que seja, que eles } \\
\text { tem um entendimento, eles já tomam parte da palavra } \\
\text { né? Já desenvolvem junto com a gente né... as } \\
\text { atividades. (...)" }\end{array}$ \\
\hline $\begin{array}{l}\text { Trato de temáticas } \\
\text { socioambientais sob a } \\
\text { perspectiva da } \\
\text { conservação ambiental } \\
\text { presente na juventude } \\
\text { local. }\end{array}$ & $\begin{array}{l}\text { “(...) Quando eu trabalhei no ano passado achei que foi } \\
\text { positivo meu trabalho, o rendimento dos alunos } \\
\text { também, conheceram muitas coisas que eles às vezes } \\
\text { não tinham noção de como era, de como seria, eles } \\
\text { acabaram conhecendo. A gente fez, em vários } \\
\text { momentos, conversamos muito quando falamos sobre } \\
\text { preservação de rio e nascentes, é uma questão pra eles } \\
\text { lá... era uma coisa nova. Tem rios e tem nascentes na } \\
\text { região deles, mas eles não tinham a questão de } \\
\text { preocupar com a preservação né? (...)" }\end{array}$ \\
\hline $\begin{array}{l}\text { Interação escola- } \\
\text { comunidade no } \\
\text { processo de elaboração }\end{array}$ & $\begin{array}{l}\text { "(...) Porque não temos referência pra fazer as pesquisa } \\
\text { né? É pouco material, na maioria das vezes a gente tem } \\
\text { que é... recorrer mesmo às pessoas da comunidade, } \\
\text { conhecimentos aí do dia a dia que as pessoas tem. }\end{array}$ \\
\hline
\end{tabular}




\begin{tabular}{|c|c|}
\hline & $\begin{array}{l}\text { egar informação e levar pras crianças pra } \\
\text { abalhando com eles. (...)" }\end{array}$ \\
\hline $\begin{array}{l}\text { ntação de } \\
\text { es } \\
\text { nbientais } \\
\text { ao consumo } \\
\text { nte de recursos } \\
\text { s em uma } \\
\text { tiva de }\end{array}$ & $\begin{array}{l}\text { “(...) Questão de lixo também que é jogado... lá tem uma } \\
\text { questão que é o desperdício de água. Agora, tá até } \\
\text { mais controlado. As pessoas não tinham torneira e a } \\
\text { água derramando } 24 \text { horas. Também trabalhei essas } \\
\text { questão dentro da disciplina que trabalha a preservação } \\
\text { de rios e nascentes. (...)" }\end{array}$ \\
\hline $\begin{array}{l}\text { A aprendizagem das } \\
\text { temáticas trabalhadas } \\
\text { tem função importante } \\
\text { na formação pessoal e } \\
\text { profissional dos }\end{array}$ & $\begin{array}{l}\text { "(...) No meu ponto de vista o aspecto positivo foi mais } \\
\text { nessa questão de preservação de rios e nascentes e } \\
\text { também sobre o uso de agrotóxicos né? Foi um tema } \\
\text { que eu estava trabalhando e eu conhecia o tema porque } \\
\text { antes de eu trabalhar na área da Educação, eu trabalhei } \\
\text { muito tempo mexendo com agrotóxicos e eu conheço. } \\
\text { (...)" }\end{array}$ \\
\hline $\begin{array}{l}\text { Reflexões sobre a } \\
\text { capacidade criativa da } \\
\text { escola como } \\
\text { sistematizadora de } \\
\text { conhecimentos, } \\
\text { quando os educadores } \\
\text { articulam-se em torno } \\
\text { da necessidade de } \\
\text { elaboração curricular } \\
\text { acompanhada da } \\
\text { arrticinar̃̃n }\end{array}$ & $\begin{array}{l}\text { “(...) É porque quando o material é criado pelas } \\
\text { necessidades da comunidade, das comunidades que é } \\
\text { trabalhada essa disciplina, às vezes, muitas vezes a } \\
\text { gente coloca conhecimentos, cultura, costumes da } \\
\text { própria comunidade quando o material ele é criado lá } \\
\text { em cima, como uma hierarquia de cima pra baixo eles } \\
\text { não conhecem. Às vezes colocam um tipo de material, } \\
\text { colocam uma ideia, um ponto de vista que, quando você } \\
\text { vai na comunidade é outra realidade né? É diferente. } \\
\text { (...)" }\end{array}$ \\
\hline
\end{tabular}




\subsection{Espaços de Saberes e Fazeres Quilombolas}

"Outro saber fundamental à experiência educativa é o que diz respeito à sua
natureza. Como professor preciso me mover com clareza na minha prática.
Preciso conhecer as diferentes dimensões que caracterizam a essência da
prática, o que me pode tornar mais seguro no meu próprio desempenho. (...)
A nossa capacidade de aprender, de que decorre a de ensinar, sugere ou,
mais do que isso, implica a nossa habilidade de aprender a substantividade
do objeto aprendido" (Freire, P. 1996, p. 76).

É uniforme o discurso entre os educadores quando problematizam a questão relativa a outros espaços da sociabilidade comunitária, não circunscritos àquele ocupado pela escola, em que seja possível uma aprendizagem relativa aos saberes e fazeres quilombolas. No discurso docente, é possível identificar duas situações principais em que há possibilidade direta de aprendizagem, seja no âmbito familiar ou no âmbito social mais amplo. A primeira, como já descrito anteriormente, relaciona-se a atividades agropastoris desenvolvidas e estabelecidas na relação de subsistência a partir do trabalho com a terra; a segunda repousa especificamente sobre o momento da colheita do capim-dourado, para confecção de artesanato, a partir do mês de setembro, evento marcado pela confraternização durante a chamada Festa da Colheita.

É importante ressaltar que ambos os eventos estão intrinsecamente relacionados ao uso da biodiversidade, principalmente vegetal, na elaboração coletiva dos saberes a ela associados. Ambas são caracterizadas por uma participação familiar intensa e mobilizam diferentes pessoas nas práticas relacionadas a esses saberes, continuamente, ao longo do calendário produtivo. Ao trazerem tais aspectos para as discussões em sala de aula, pode-se vislumbrar a experiência cotidiana como construtora das elaborações discursivas educativas escolares.

Mesmo não havendo formalidade e objetivação de aprendizagem nas atividades vivenciadas com a comunidade, percebe-se uma óbvia articulação escolacomunidade que possibilita, aos estudantes, a percepção de que os Saberes e Fazeres Quilombolas, antes de se tornarem conhecimento escolarizado, estão presentes na realidade cotidiana, pela relação estabelecida com a vida no campo e as atividades agropastoris realizadas pelos comunitários. 
Essas atividades ligadas ao conhecimento transmitido oralmente ao longo das gerações, que privilegiam valores e aptidões dos seus antepassados históricos e permitem um fluxo de saberes, que têm início nessas gerações, é apropriado pelas novas gerações e, no presente momento, oficializado curricularmente pelo sistema de ensino com a mediação dos educadores e seu mecanismo de valorização de uma identidade quilombola, representada pela sua relação com a terra, com a biodiversidade, a biorregião ocupada e as simbologias presentes nas representações coletivas dessa sociedade.

É possível perceber, nas interlocuções dos professores, a importância atribuída ao conhecimento da biodiversidade local mediado pelo trabalho no campo, como garantia de sobrevivência das diferentes populações que se sucederam na história da comunidade, havendo uma interligação dos usos de elementos naturais da biodiversidade vegetal em diferentes aspectos, desde os alimentícios aos médicos. Esses saberes ligados à biodiversidade, quando transpostos para o currículo, implícito ou explícito, do novo componente curricular, trazem à tona a discussão sobre a transversalidade do tema Meio Ambiente no cenário escolar.

A mobilização familiar para as atividades produtivas e o interesse dos pais e responsáveis familiares em levar seus filhos para o roçado é um aspecto significativo que exemplifica uma prática social coletiva, cujos momentos de aprendizado podem ser influenciadores das concepções sobre natureza, mecanismos de produção, conservação ambiental e valorização dos códigos de pertencimento comunitários. $O$ entendimento da natureza como fonte de informações úteis para a sobrevivência, remete a uma concepção naturalista de meio ambiente, abordando importantes aspectos ligados a práticas de conservação ambiental no uso de produtos, recursos e serviços ambientais, advindos da relação ser humano-meio ambiente. A possibilidade de aprender sobre a natureza, na convivência com o ambiente físico, biológico e social do entorno, associado aos conhecimentos tradicionais das famílias, ligados ao trabalho com a terra, abre uma importante discussão sobre o papel da oralidade, como traço distintivo da cultura quilombola na aprendizagem sobre temáticas socioambientais.

É evidente, no discurso dos professores, uma preocupação relativa às mudanças sociais e culturais que as novas gerações da comunidade estão 
experimentando, ligadas à não realização de antigas práticas que foram desenvolvidas ao longo do tempo, práticas associadas à produção de alimentos pelo uso de biodiversidade vegetal, culminando em uma ênfase na importância da disciplina como estratégias de desenvolvimento e resgate desses saberes, em processo de ressignificação pelas atuais gerações.

Especificamente sobre os usos de capim-dourado, entende-se que a colheita é uma atividade associada a práticas sustentáveis de manejo da espécie, vinculadas a motivos tanto ecológicos quanto identitários; primeiro, porque há o reconhecimento da importância dos campos e veredas como ecossistemas em que se pode encontrar a espécie, fonte de renda e simbologias para a comunidade; segundo, porque tais espaços do território representam uma memória da passagem dos fundadores da comunidade pelo local. A relação afetiva estabelecida com as veredas guarda uma dimensão de pertencimento notória desse povo tradicional e abre-se uma possibilidade de discussão sobre Conservação do Cerrado por meio das identidades dos habitantes.

Esse enfoque conservacionista, relacionado ao manejo de capim-dourado, é uma preocupação percebida em vários discursos presentes nas interações comunitárias, desde os ambientes de ensino-aprendizagem oficiais até as conversas informais em outros ambientes, incluindo aquelas ligadas à arte por meio das canções populares cantadas pelos músicos da comunidade. É importante aqui enfatizar que as problemáticas socioambientais associadas ao manejo da espécie possam ser compreendidas pelos estudantes na relação com as famílias e no trabalho pedagógico dos professores, visto que a base produtiva da comunidade reside no extrativismo e artesanato do vegetal, a despeito do fato de a produção agrícola de outras espécies objetivar principalmente o consumo familiar interno e de que várias relações simbólicas ligadas, à memória coletiva dos moradores interagem com o capimdourado.

É interesse notar que, mesmo que algumas atividades de ensino não tenham sido realizadas, os educadores planejaram momentos de encontro dos estudantes com as vivências comunitárias relacionadas a tal atividade produtiva. Essa articulação representa um vínculo com a comunidade, com vistas ao compartilhamento de saberes com outros sujeitos, produzindo um discurso coletivo não centralizado 
somente na escola enquanto instituição formadora e estimula a continuidade desse fluxo de saberes propiciado pela oralidade que constantemente recria a identidade quilombola.

Por fim, ressaltamos neste metatexto, o constante fortalecimento da interface escola-comunidade elaborado pelo pensamento dos educadores, permitindo, por um lado, a associação com as pessoas mais velhas da comunidade, detentoras de saberes ligados à produção agrícola extrativista, usando elementos da biodiversidade local e produzindo diferentes bens; e, por outro, a articulação com pesquisadores e instituições externos que, em busca de compreensão sobre seus objetos de pesquisa são convidados a integrar-se à realidade local, a fim de colaborarem na sistematização de saberes e na emancipação comunitária.

$\mathrm{Na}$ tabela 6, encontram-se trechos das interlocuções dos profissionais associadas a interpretações baseadas no referencial teórico adotado neste trabalho e na subjetividade do pesquisador/analista, permitindo melhor visualização sobre a discussão apresentada neste metatexto temático.

Tabela 6. Quadro analítico do metatexto V - Espaços de Saberes e Fazeres Quilombolas.

\begin{tabular}{|l|l|}
\hline $\begin{array}{l}\text { Referência direta às } \\
\text { duas principais } \\
\text { atividades }\end{array}$ & $\begin{array}{l}\text { “...) É... tem um Saber e Fazer muito importante que a } \\
\text { gente.. que eles aprendem é quando a gente vai pro } \\
\text { campo e quando a gente vai pra colheita do capim (...)" } \\
\text { metatexto. }\end{array}$ \\
$\begin{array}{l}\text { Aprendizagem no } \\
\text { núcleo familiar sobre } \\
\text { história e cultura } \\
\text { quilombola durante a } \\
\text { oportunidade de } \\
\text { participação no } \\
\text { trabalho no campo. }\end{array}$ & $\begin{array}{l}\text { interesse de levar todas as crianças. Eu também tive o } \\
\text { privilégio de levar os meus e eles sempre ficaram assim } \\
\text { encantados... dizer que olha há 150 anos morava } \\
\text { alguém aqui, aqui era o lugar de seu tataravô pescar, } \\
\text { aqui é uma fonte de seu fulano de tal. Assim... e eles } \\
\text { ficaram impressionado em ver e ali ele quer ver o que } \\
\text { foi conservado né? Os cuidados, o zelo que tinha }\end{array}$ \\
\hline naquele lugar (...)"
\end{tabular}


Aprendizagem sobre

temáticas ligadas à

conservação

socioambiental

associada à história da

comunidade.

Usos de biodiversidade vegetal em sentido

médico associado à cultura quilombola.

Elementos da

biodiversidade vegetal que são utilizados no trabalho no campo e produzidos pela agricultura quilombola.

Aprendizagem no núcleo familiar sobre os elementos da biodiversidade local e as formas e os períodos de cultivo de determinadas plantas.
“(...) Então assim, lá eles aprendem que tinha... que tem que conservar a natureza, tem que conservar que não há capim, não há buriti, não há água, não há um puçá, a mangaba. Então assim quando a gente leva pra lá há uma história contada pra eles: 'Olha, esse aqui alguém morou aqui, alguém teve aqui, aqui era uma roça' (...)" “(...) Teve uma menina que perguntou: 'Professora, como é que adoecia aqui? Como é que a pessoa sobrevivia aqui neste lugar? Não tem ninguém, é longe, nós saímos de lá de manhã e chegamos aqui meio-dia e a pé, sem carro!' A gente explicava: 'Não, eles tinha remédio, tinha remédio de pau, tinha a fé mesmo e não tinha como desistir né? (...)"

“(...) Deixa eu ver se consigo mostrar. Ele é daqui da comunidade, é o pai da professora Tatiana. Deixa eu ver se eu tenho uma coisinha bem aqui. (..) Aqui oh! Olha ele aqui. Essa aqui é a roça de esgoto. Essa aqui é a capemba. Nós botá tudo ai. Tem a mandioca, tem a banana e a capemba. A capemba é do buriti. Aqui tem tudo. Aqui tem a batata, aqui tem a banana, aqui tem a mandioca, aqui tem o arroz, é perfeito. (...)"

“(...) Eu acredito assim né... que eles junto com os pais né... seus familiares, eles vão aprendendo cada vez mais uma coisa né? Porque tem que fazer assim... aquilo que não pode fazer e vão junto com os pais desenvolvendo né? Com esse desenvolvimento por causa de ir pra roça né? Como plantar, o tempo pra colher, o tempo que tem que plantar né? Agora o tempo da chuva, só pode plantar essa... no caso a mandioca, só pode plantar no início de chuva, não pode plantar no 
meio. Eu acredito que eles tão, que eles tão aprendendo. (...)"

Participação dos
estudantes na interação
discursiva
contextualizada em sala
de aula.

Importância do novo componente curricular diante do processo de ressignificação cultural das atuais gerações sobre os saberes socioambientais comunitários.

Importância da execução de planejamentos de aulas de campo que permitam o diálogo entre os saberes presentes nas atividades produtivas e a expectativa de aprendizagem dos conhecimentos escolares.
“(...) Mesmo sem ser uma disciplina. Eles têm isso na mente, por causa que quando a gente tá desenvolvendo esse trabalho em sala de aula, fazendo esse tipo de leitura, essas palestras, essa fala é oral né? Eles tão também entrando nessa fala né? Então eu acredito que eles sabem também. (...)"

(...) Eles deixaram agora com essa cultura né... com esse desenvolvimento dessa... matéria. Aí Fazeres e Saberes eu acredito que eles vão ter que aprender. (...) Trazer pra escola como é que tira o óleo do coco né? O dendê do coco. Tudo isso eu fiz quando eu era criança e quando não tinha a farinha da mandioca, a gente fazia o dendê do coco, fazia a farinha do dendê do coco. (...)"

“(...) Foi falado ano passado assim sobre atividades que seria feito, mas elas não aconteceram, mas eu no meu ponto de vista acho que era muito importante falar, ou seja, levar as crianças para lá mesmo que eles já conhecendo a importância. É porque na comunidade eles trabalha a roça de toco e de esgoto. Então pra comunidade Saberes e Fazeres Quilombolas, pra essas pessoas que nasceram e cresceram e vai passando os conhecimentos pra seus filhos eu acho que isso é importante que aconteça porque hoje você percebe que muitas coisas tão se perdendo. Hoje, às vezes tem crianças que é filho de pessoas da comunidade remanescente de quilombo, mas eles... muitos conhecimentos que o pai teve, os pais não tão mais passando pros filhos. (...)" 


\begin{tabular}{|c|c|}
\hline $\begin{array}{l}\text { Diagnóstico sobre o } \\
\text { contexto cultural atual } \\
\text { e a relevância das } \\
\text { discussões identitárias } \\
\text { permitidas pela nova } \\
\text { disciplina. }\end{array}$ & $\begin{array}{l}\text { “...) Ai, o ano passado foi falado muito sobre umas } \\
\text { visitas a uma roças de toco que hoje é poucas pessoas } \\
\text { que cultiva isso, mas elas não aconteceram, mas eu } \\
\text { acho que se elas acontecerem ela é assim... ela tem } \\
\text { uma importância muito grande porque muitas crianças } \\
\text { mesmo sendo da própria comunidade elas não } \\
\text { conhecem os costumes que o pai foi criado é... as } \\
\text { tradições que era feito não num passado muito distante, } \\
\text { mas num passado recente só que as pessoas hoje em } \\
\text { dia com a modernidade... as pessoas tá mudando. Hoje } \\
\text { você vê muita gente que plantava e hoje não planta } \\
\text { mais. Tem pessoas que na própria comunidade não } \\
\text { conhecem a roça de toco. (...)” }\end{array}$ \\
\hline $\begin{array}{l}\text { Relação comercial } \\
\text { estabelecida pela } \\
\text { comunidade com o } \\
\text { capim-dourado pode } \\
\text { minimizar outras } \\
\text { práticas produtivas, } \\
\text { modificando a relação } \\
\text { dos comunitários com } \\
\text { outras espécies } \\
\text { vegetais. }\end{array}$ & $\begin{array}{l}\text { “...) Porque eu vejo assim que a comunidade... ela } \\
\text { trabalha né... só o capim-dourado, mas aí todo mundo } \\
\text { focou no capim-dourado e aí os costumes de família, de } \\
\text { tradição que nós vimos foram se perdendo. Tá se } \\
\text { perdendo. A questão da roça de toco que eu falei agora } \\
\text { e da roça de esgoto. Aí todo mundo só fala no capim- } \\
\text { dourado, na costura lá do capim-dourado todo mundo } \\
\text { sabe. Mas, aí vai falar na questão da roça de toco, do } \\
\text { esgoto, aí a maioria das crianças já nem conhecem né? } \\
\text { Porque tá tendo uma transição, uma mudança, } \\
\text { deixando de cultivar os costumes antigos nas roças ali } \\
\text { pra mexer apenas com a costura do capim-dourado. } \\
\text { (...)” }\end{array}$ \\
\hline
\end{tabular}

1.6. Proveniência dos temas

"Me sinto seguro porque não há razão para me envergonhar por desconhecer
algo. Testemunhar a abertura aos outros, a disponibilidade curiosa à vida, a
seus desafios, são saberes necessários à prática educativa. (...) A razão ética
da abertura, seu fundamento político, sua referência pedagógica; a boniteza
que há nela como viabilidade do diálogo. A experiência da abertura como
experiência fundante do ser inacabado que terminou por se saber inacabado. 
Seria impossível saber-se inacabado e não se abrir ao mundo e aos outros à procura de explicação, de respostas a múltiplas perguntas" (Freire, P. 1996, p. 153).

A disciplina Saberes e Fazeres Quilombolas possui uma estruturação prévia, definida pela Secretaria Estadual de Educação, em um documento enviado para as escolas que receberam esse novo componente curricular. No entanto, é interessante verificar se, na prática pedagógica dos professores, a proveniência das temáticas discutidas giram em torno dessa prévia estruturação ou se, no trabalho de pesquisa diagnóstica realizado por estes profissionais, outros assuntos foram abordados ou ampliados no decorrer do ano letivo. Nesse contexto, é possível identificar se, na relação professor/estudante estabelecida nos encontros pedagógicos em sala de aula, estabelece-se um princípio dialógico que permita aos estudantes orientar o sentido da aprendizagem por meio das suas expectativas de aprendizagem diante da disciplina.

Nas interlocuções apresentadas pelos professores, a estruturação curricular prévia serviu de pano de fundo para uma abordagem contextualizada, por meio de pesquisa bibliográfica e busca na comunidade sobre os temas que seriam melhor explorados em sala de aula. A intenção pedagógica é claramente associada aos diferentes aspectos simbólicos das elaborações instrumentais da comunidade, pensando em suas características de utilidade histórica, laboral, artística e memorial, acentuando a valoração a esses objetos, por meio da interação com moradores mais antigos da comunidade e o conjunto de significados sobre os produtos naturais ligados ao trabalho no campo.

Tal abordagem parece intencionar uma atividade de ensino que efetiva a contextualização dos temas como importante atributo na consolidação dos saberes escolarizados. Quando em momentos de aprendizagem na sala de aula as diferentes textualidades discursivas remetem à própria comunidade, nas figuras familiares, os sujeitos se veem diante de um conhecimento que dialoga com o seu pertencimento às relações socioambientais travadas no tecido social desse território.

Do ponto de vista docente, a constante associação entre os saberes socioambientais presentes entre os comunitários e uma perspectiva de olhar para as suas memórias pessoais-profissionais e coletivas denota uma busca de validação das discussões travadas em sala sob a fonte desses saberes nas relações familiares. Um 
dos exemplos citados sobre a Viola de Vereda, instrumento musical confeccionado utilizando o buriti, planta essencial ao modo de vida dos comunitários em âmbitos diversos, desde os alimentares aos artísticos, traz proposições que indicam importantes locuções com as simbologias coletivas repousadas nesse traço cultural.

De todo modo, o estímulo à participação dos estudantes nas interações discursivas em sala de aula é alcançado pelos professores quando viabilizam trabalhos extra classe, como a função de eles próprios entrevistarem os seus pais e avós na intenção de reforçar a curiosidade epistemológica desses estudantes e consolidar as aprendizagens construídas nesses diferentes contextos, familiar e escolar.

É nesse sentido, que, por mais que não tenha ocorrido uma avaliação diagnóstica específica entre os estudantes, inventariando temas de trabalho de interesse para o ano letivo, parece ter ocorrido uma rede interativa entre estudantes, famílias e professores, ao tratar o novo componente curricular. Na possibilidade direta de tratar temáticas diretamente contextualizadas ao cotidiano comunitário, reconhecese a emergência de uma sala de aula dialógica, caracterizada por momentos de aprendizagem que redesenham a hegemonia dos discursos, diante de possíveis conflitos epistemológicos e configuram um ambiente de aprendizagem cuja participação interativa é estimulada.

Apresentando-se, portanto, um outro aspecto significativo do papel social e político do profissional da educação ao desempenhar sua função, de certo modo caracterizado como educador-educando; educadores preocupados com o processo da mediação pedagógica, colocando-se como aprendizes de saberes que possam estar vinculados aos conhecimentos dos estudantes.

É importante ressaltar o fato de que a escola presente na comunidade do Mumbuca atende estudantes de outras duas comunidade próximas: Carrapato e Ambrósio. Essas comunidades têm origem comum e, possivelmente, vivências socioambientais similares, por estarem inseridas no mesmo território. A territorialização quilombola respeitada não se resume somente aos estudantes do Mumbuca, e a práxis pedagógica dos educadores busca identificar as diferenças ou similaridades entre as três comunidades, contextualizando os saberes e permitindo 
que tais peculiaridades sejam expressas nas ações dos estudantes, em seus trabalhos, falas, vivências e memórias.

A participação dos estudantes, estimulada pela realização de entrevistas com seus familiares, apresenta um importante sentido de promoção de dinâmicas de aprendizagem participativas, colaborativas, articulando as vozes de diferentes pessoas na produção do conhecimento e permitindo aos estudantes um tipo de aprendizagem que não esteja circunscrito somente aos muros da escola, mas à percepção de que os saberes oficializados na disciplina estão presentes em suas relações cotidianas familiares, produtivas, artísticas, alimentares e em outros aspectos da vida social.

Da mesma forma, diante das dificuldades procedimentais apresentadas pelos educadores, aqui discutidas, as fontes de informação para a disciplina também incluíram os trabalhos acadêmicos já desenvolvidos na comunidade. Com isso, discutimos criticamente a utilização de diferentes formatos de pesquisa acadêmica que privilegiam novas abordagens metodológicas, que dialogam com as necessidades dos sujeitos participantes, em uma perspectiva de emancipação e empoderamento, e que estejam vinculados à questão educativa/formativa.

O fato de, em parte, os professores terem realizado pesquisa bibliográfica relacionada ao tema da disciplina abre um importante cenário de pesquisa, colaborativa, de produção de conhecimentos e sistematização educativa formal, que associa a história da comunidade e os diferentes usos de biodiversidade local, pois, no discurso dos professores, é latente a observação sobre a possibilidade de aprendizagem na relação com a natureza. Aprender com a natureza, na experiência humana assentada historicamente sobre o meio ambiente e levando em consideração aspectos culturais e simbólicos deste povo, posiciona a representação do ser humano como sujeito que pensa o meio ambiente, atribuindo à disciplina Saberes e Fazeres Quilombolas uma singularidade neste contexto.

Por fim, considera-se a importância da posição de professores-pesquisadores, dialogando com as suas práticas e processos formativos, as vivências comunitárias e o entorno da escola, para identificação de temáticas a serem oficializadas no trato escolar, relativas a esse universo de saberes. Percebe-se uma dinâmica de emancipação pelos educadores, revestida de uma perspectiva de empoderamento 
pessoal e reflexão sobre suas condutas enquanto sujeitos com potencial de sistematização de saberes.

Tal dinâmica viabiliza um projeto educativo que elabora uma postura de sujeitos pesquisadores e avaliadores das ações necessárias para o desenvolvimento de uma práxis pedagógica crítica como educadores. Ainda, o destacamento dessa postura dialoga com uma perspectiva de ensino democrática e emancipatória típica da Educação Popular, que posiciona a figura do professor como mediador cultural inserido no ambiente escolar, com uma representação profissional que alia a questão política oficial necessária à sua prática com questões pedagógicas mais amplas, associadas à sua formação continuada e à contextualização dos saberes oriundos de diferentes frentes e demandas.

$\mathrm{Na}$ tabela 7, encontram-se trechos das interlocuções dos profissionais associadas a interpretações baseadas no referencial teórico adotado neste trabalho e na subjetividade do pesquisador/analista, permitindo melhor visualização sobre a discussão apresentada neste metatexto temático.

Tabela 7. Quadro analítico do metatexto VI - Proveniência dos temas.

Fonte de
conhecimentos para o
trato da disciplina
repousa sobre a
história da comunidade
no uso de elementos
culturais.

Entrevistas com moradores mais velhos e experiência pessoal e profissional úteis à sistematização curricular da disciplina.
“(...) E nós trabalhamos isso, essa importância que vem de origem e isso não é de agora, isso vem de muito tempo, vem passando. Isso não acabou e tem que dá continuidade. Isso... tem uma história, não vem, não foi dali que surgiu, não foi daqui não, já vem de muitos anos, de muitos antepassados que é um saber que é passado de pai pra filho, de geração em geração. (...)" “(...) Vieram de entrevistas que a gente fez com os patriarcas mesmo. Da própria experiência que às vezes a gente ouviu o pai falar, o avô falar e a gente foi, aprofundou nessas pesquisas e pegou duas, três fontes né? $\mathrm{E}$ fizemos isso... trabalhamos, por exemplo, a Violinha de Vereda né? Quem foi que incrementou? De onde veio? Como era surgido? Pra que servia uma 


\begin{tabular}{|c|c|}
\hline & $\begin{array}{l}\text { violinha de vereda? Pra uma socialização, uma } \\
\text { diversão, pra compartilhar, ver as coisas... pra } \\
\text { compartilhar brincadeiras (...)" }\end{array}$ \\
\hline $\begin{array}{l}\text { Estimulo à participação } \\
\text { dos estudantes na } \\
\text { elaboração discursiva } \\
\text { em torno da disciplina, } \\
\text { por meio das pesquisas } \\
\text { com seus familiares e } \\
\text { suas relações } \\
\text { socioambientais } \\
\text { coletivas. }\end{array}$ & $\begin{array}{l}\text { "(...) O que é que vai ser discutido sim. Ou esse é... o } \\
\text { quê que tem na sua comunidade, por exemplo? Eles } \\
\text { entrevistaram pai, entrevistaram avô, entrevistaram } \\
\text { alguém que conhecia né? Como é que era os } \\
\text { brinquedos? Como é que eles andava? Como é que era } \\
\text { a roupa? Como é que compartilhava as coisas? Como } \\
\text { é que era? Até o respeito como é que era? 'Daquele pé } \\
\text { de macaúba pra lá é do Seu João, não precisava ter } \\
\text { cerca, não precisava ter documento, ninguém ia lá pedir } \\
\text { ao Seu João'. (...)" }\end{array}$ \\
\hline $\begin{array}{l}\text { Pesquisa bibliográfica } \\
\text { como recurso de busca } \\
\text { por referencial teórico } \\
\text { para o trabalho } \\
\text { pedagógico. }\end{array}$ & $\begin{array}{l}\text { “(...) Aí nós fomos pesquisar, fomos falar sobre... pegar } \\
\text { as pesquisas desses livros (...) A gente...como eu } \\
\text { trabalhava lá na Naturatins, eu tinha uns livros, então a } \\
\text { gente foi folheando e fomos achando o buriti, a seda, } \\
\text { como tira, o pé da árvore do buriti, eles secam a fruta } \\
\text { pra fazer o suco, pra fazer o doce, a palha faz o cofo } \\
\text { né? Faz a rede até pra se deitar, a madeira faz a viola } \\
\text { do buriti, a raiz o adubo, a madeira dele né, ele produz } \\
\text { um adubo muito rico e ele ainda tem um vinho que é } \\
\text { muito difícil o buriti, então ele é uma palmeira que tudo } \\
\text { nela aproveita. (...)” }\end{array}$ \\
\hline $\begin{array}{l}\text { Contextualização } \\
\text { histórica sobre as } \\
\text { práticas produtivas da } \\
\text { comunidade } \\
\text { associadas ao } \\
\text { artesanato do capim- } \\
\text { dourado. }\end{array}$ & $\begin{array}{l}\text { “(...) Então nós fomos trabalhando esses Fazeres né? } \\
\text { Fomos trabalhando, falamos sobre a roça de toco, } \\
\text { falamos sobre o artesanato do capim-dourado, sobre } \\
\text { como fazer. Aí veio a economia né? Como foi o } \\
\text { desenvolvimento da economia.... desenvolveu como foi } \\
\text { fabricada, a fábrica dos brincos, dos sousplat. De }\end{array}$ \\
\hline
\end{tabular}




\begin{tabular}{|c|c|}
\hline & $\begin{array}{l}\text { primeiro só fazia umas coisas e depois foi evoluindo né? } \\
(\ldots) "\end{array}$ \\
\hline $\begin{array}{l}\text { Percepção sobre a } \\
\text { importância de a } \\
\text { prática educativa incluir } \\
\text { atividades de pesquisa } \\
\text { promotoras de } \\
\text { formação continuada } \\
\text { docente. }\end{array}$ & $\begin{array}{l}\text { “(...) O que eu senti falta foi só de não ter suporte, de } \\
\text { não ter às vezes material e muitas vezes você precisa } \\
\text { é... buscar esse material, mas só que as pessoas às } \\
\text { vezes a gente também peca em alguns aspectos } \\
\text { porque a gente acostuma a encontrar coisas prontas } \\
\text { (...) e muitas vezes as pessoas acabam passando a } \\
\text { informação pra frente... informação errada porque ele } \\
\text { não investiga se aquilo é verdade ou não, então você } \\
\text { constrói uma zona de conforto e se estabelece ali e fica } \\
\text { com preguiça de mudar, de buscar recursos. (...) Às } \\
\text { vezes a gente reclama de falta do material, mas isso } \\
\text { também incentiva você a pesquisar né? (...)” }\end{array}$ \\
\hline $\begin{array}{l}\text { Avaliação diagnóstica } \\
\text { entre os estudantes } \\
\text { como instrumento de } \\
\text { coleta e sistematização } \\
\text { de informações úteis } \\
\text { para a prática docente } \\
\text { contextualizada. }\end{array}$ & $\begin{array}{l}\text { “(...) Eu acho que seria bom até no início no... vamos } \\
\text { dizer assim... no início do ano você colocar essa } \\
\text { questão pra eles. O quê que eles pensam? Pra eles é... } \\
\text { pensar, refletir e te dar um retorno. 'O quê que você } \\
\text { acha que essa disciplina vai abordar? Qual seria a } \\
\text { importância dessa disciplina?' Eu acho que seria boa a } \\
\text { gente colocar pra eles e depois, já que é os professor } \\
\text { que tá buscando material, porque não tem material } \\
\text { pronto, então colocar os temas de todos os bimestres. } \\
\text { 'O quê que você acha que isso contribui no seu dia a } \\
\text { dia? Será que isso é verdade que os Saberes e Fazeres } \\
\text { Quilombolas têm esses conhecimentos? (...)" }\end{array}$ \\
\hline $\begin{array}{l}\text { Abordagem diagnóstica } \\
\text { produtora de } \\
\text { encaminhamentos } \\
\text { metodológicos na sala } \\
\text { de aula, estabelecendo }\end{array}$ & $\begin{array}{l}\text { “(...) E até alguns pontos que precisam ser mais assim, } \\
\text { vamos dizer, aprofundados, porque tem algumas coisas } \\
\text { que às vezes não precisa aprofundar porque o aluno já } \\
\text { conhece, aí já vai ser uma coisa que em vez de você } \\
\text { é... falar pra eles ou trabalhar com eles, você querer }\end{array}$ \\
\hline
\end{tabular}




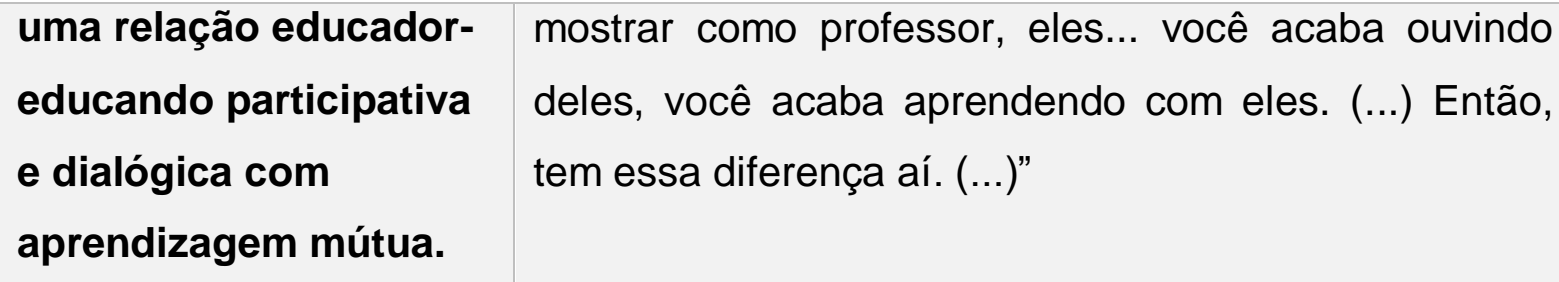

\title{
2. Planejamentos de atividade de ensino
}

\begin{abstract}
“(...) Faz parte das condições em que aprender criticamente é possível, a pressuposição por parte dos educandos de que o educador já teve ou continua tendo experiência da produção de certos saberes e que estes não podem a eles, os educandos, ser simplesmente transferidos. Pelo contrário, nas condições de verdadeira aprendizagem os educandos vão se transformando em reais sujeitos da construção e da reconstrução do saber ensinado, ao lado do educador, igualmente sujeito do processo. Só assim podemos falar realmente de saber ensinado, em que o objeto ensinado é apreendido na sua razão de ser e, portanto, aprendido pelos educandos" (Freire, P. 1996, p. 29).
\end{abstract}

\subsection{Roça de esgoto/toco ${ }^{2}$}

Assuntos:

(1) Plantas cultivadas nesse tipo de roçado (batata, feijão, gergelim, maxixe, banana, abóbora e mandioca);

(2) Tipo de "terra" utilizada nesse roçado;

(3) Períodos de tempo para plantio de cada espécie entre estação seca e chuvosa;

(4) Conceito de "rego" ou canal de drenagem da água utilizada no roçado e

(5) Tempo de existência desse roçado de esgoto na comunidade.

Contexto na comunidade: A roça objeto de estudo é propriedade dos familiares da docente e a proprietária do roçado seria entrevistada pelos estudantes sobre as questões acima mencionadas.

Público: Estudantes do $7^{\circ}$ ano do Ensino Fundamental

\footnotetext{
${ }^{2}$ Roça de toco e roça de esgoto são dois sistemas agrícolas tradicionais do Jalapão e associados ao manejo de fogo. A primeira, geralmente, acontece em áreas de relevo acidentado e é baseada na agricultura de corte e queima em áreas de "terra seca". As roças de esgoto, base do sistema agrícola local, acontece em áreas de tipo de solo rico em matéria orgânica, sem necessidade de adubação, abertas por meio da drenagem do solo e da derruba e queima da vegetação de vereda (Borges et al., 2016).
} 
Primeiro momento: Em aula anterior à visita ao roçado, discutir em sala de aula a seguinte questão: "O que os estudantes pensam sobre a importância da roça de esgoto?" e solicitar que escrevam uma redação sobre a discussão realizada.

Segundo momento: Visita propriamente dita e discussão coletiva dos assuntos apresentados acima, com a participação da proprietária da roça estudada.

Terceiro momento: Em sala de aula novamente, discutir com o grupo sobre o que aprenderam e as informações que acharam mais interessantes durante a visita. Dar enfoque nessa discussão sobre a importância que a roça de esgoto assumiu para as pessoas pioneiras na comunidade, que não tinham acesso a vários bens hoje disponíveis para as atuais gerações, como transporte, supermercados, energia elétrica etc. Pedir que escrevam sobre essas reflexões.

\subsection{Conservação socioambiental}

Assuntos:

(1) Conservação ambiental;

(2) Consumo de recursos hídricos da comunidade;

(3) Plantas e animais do cerrado.

Contexto na Comunidade: Arredores da nascente do Rio Sono.

Público: Estudantes do 8ํano do Ensino Fundamental

Primeiro momento: Discussão com os estudantes sobre o tema da atividade prática e da relação estabelecida pela comunidade com a conservação ambiental e os usos de recursos hídricos locais.

Segundo momento: Caminhada com os estudantes ao redor da comunidade para estimular a observação do ambiente natural e as principais plantas e animais encontrados ao longo do caminho, até a chegada do grupo na nascente do Rio Sono. Ao longo do percurso, os estudantes devem realizar o registro fotográfico das espécies encontradas e entrevistar os moradores locais sobre o tema "preservação do rio", a fim de obter informações sobre a preservação de rios e nascentes.

Terceiro momento: Em sala, organizar o material produzido pelos estudantes (fotos e entrevistas). As entrevistas devem responder às seguintes questões: (1) origem das pessoas nas comunidades visitadas, a saber, Comunidades do Prata e do 
Carrapato; (2) os meios de subsistência dos entrevistados; (3) o que significou nas suas vidas a criação do Parque Estadual do Jalapão e (4) o que devemos fazer para preservar as nascentes de rios da região?

\subsection{Instrumentos de trabalho no campo}

Assuntos/Instrumentos:

(1) Tapiti;

(2) Cofo;

(3) Balaio;

(4) Esteira;

(5) Viola de vereda.

Contexto na Comunidade: A confecção de instrumentos de trabalho constitui uma articulação entre as habilidades de determinados comunitários na produção desses utensílios e os assuntos que são trabalhados na disciplina Saberes e Fazeres Quilombolas. Os comunitários são convidados a expor suas habilidades no preparo dos instrumentos, para os alunos, no contexto escolar, estabelecendo uma associação entre saberes comunitários, uso de biodiversidade e questões práticas ligadas ao trabalho como mediação ser humano/cultura/meio ambiente.

Público: Estudantes da primeira etapa do Ensino Fundamental, o chamado Ensino Fundamental I (1음 ao $5^{\circ}$ ano).

Primeiro momento: Os estudantes e professores pesquisariam entre os comunitários quais são as pessoas que possuem as habilidades de confecção dos instrumentos citados; remetendo aos seus círculos familiares íntimos e elaborando uma lista de recursos materiais necessários para a confecção e exposição dos utensílios.

Segundo momento: Os estudantes responsabilizam-se pela busca dos materiais para a atividade e os professores organizam, no cronograma da disciplina, o espaço e os momentos adequados para o evento planejado. Durante o evento, os comunitários convidados produzem e/ou expõem os utensílios que fabricam e explicam aos estudantes sobre a importância dos mesmos em sua relação com a cultura quilombola. 
Terceiro momento: Após a exposição, realizar uma discussão em sala sobre os instrumentos de trabalho apresentados e discutir questões ligadas à preservação da memória comunitária e ao uso de elementos naturais do Cerrado na facilitação da vida em comunidade.

\section{4. "Caixinha de segredos"}

Assunto: Confecção de brinquedo a partir da palha do Coco Piaçava.

Contexto na comunidade: Essa atividade prática tem relação intrínseca com a história pessoal da educadora proponente e as questões ligadas ao brinquedo infantil que aprendeu com seus pais. Pode-se fazer uma articulação com os brinquedos que as crianças na comunidade mais utilizam atualmente e a relação desses brinquedos com o ambiente social e natural que estão inseridos.

Público: Estudantes da primeira etapa do Ensino Fundamental, o chamado Ensino Fundamental I ( $1^{\circ}=$ ao $5^{\circ}$ ano).

Primeiro momento: Confecção, pela professora e seus estudantes, em sala de aula, da "Caixinha de Segredos"; um brinquedo produzido a partir de três palhas do coco piaçava, em formato trançado, onde é possível inserir em seu interior pequenos grãos (pedra, feijões, arroz, etc.) para produzir sonoridade semelhante a um chocalho.

Segundo momento: Discutir com os estudantes quais são as brincadeiras atuais que eles praticam, individualmente e coletivamente, permitindo traçar um paralelo entre o universo do brincar que a educadora experimentou na infância e o das novas gerações.

Terceiro momento: Estimular os estudantes a demonstrar as brincadeiras que praticam atualmente, e discutir qual a relação dessa brincadeira com o aprendizado em família e com os usos de elementos da natureza.

\section{5. "Dunas" - ponto turístico da região ${ }^{3}$}

Assuntos:

\footnotetext{
${ }^{3}$ A região das "dunas" no Jalapão localiza-se a cerca de 80 km de distância da comunidade do Mumbuca, em estrada de terra, o que significa cerca de três horas de deslocamento. Ressalta-se que, embora seja um dos principais pontos turísticos da região, com especial beleza paisagística e natural, muitos moradores locais não o conhecem justamente por causa da distância considerável e das dificuldades de deslocamento e transporte.
} 
(1) Tipos de solo presentes no Cerrado;

(2) Conservação ambiental;

(3) Legislação ambiental associada ao Cerrado.

Contexto na comunidade: Esta atividade prática, caracterizada por uma "aula passeio" com os estudantes à região das dunas, é pensada como um estímulo à valorização, pelos estudantes, dos pontos turísticos da Região do Jalapão, em alguma medida desconhecidos pelos próprios comunitários. A atividade gira em torno da visita ao espaço, discussão sobre o pertencimento geográfico das pessoas ao território que abriga uma Unidade de Conservação e abordagem dos assuntos mencionados no item acima.

Público: Estudantes do 9ำ ano do Ensino Fundamental

Primeiro momento: Conversar com os estudantes sobre os principais pontos turísticos presentes no Jalapão (fervedouros, cachoeiras, comunidades e dunas) e discutir sobre o pertencimento geográfico da comunidade a estes lugares, incluindo a importância das práticas de conservação ambiental e a possibilidade de valorização da identidade cultural regional aliada ao conhecimento sobre estes locais. Planejar a visita às dunas utilizando o transporte escolar para chegar à região.

Segundo momento: Durante a visita, estimular os estudantes a fotografarem o lugar visitado, seus elementos característicos e os detalhes que Ihes causarem questionamentos. Estimular que elaborem perguntas para a discussão em sala, em momento posterior. Em grupo, no momento da visita, expor aos alunos o processo físico de formação das Dunas e a ação dos órgãos e entidades locais na conservação ambiental da região.

Terceiro momento: Em sala, retomar as questões elaboradas pelos estudantes discutindo suas dúvidas e impressões sobre a visita. Solicitar que os estudantes produzam um texto, utilizando como estímulo as fotografias tiradas por eles, que represente seus aprendizados durante a visita.

\subsection{Alimentação quilombola e os frutos do Cerrado}

Assuntos:

(1) Diversidade de frutos do Cerrado; 
(2) Saberes e Fazeres Socioambientais;

(3) Alimentação quilombola.

Contexto na comunidade: Essa atividade relacionada à alimentação quilombola e sua articulação com a biodiversidade do Cerrado abrange o contexto cotidiano comunitário e o conjunto de saberes familiares a respeito dos usos de biodiversidade vegetal na região, estabelecendo um elo entre os saberes científicos associados à alimentação, ecológicos associados ao manejo de frutos, e identitários associados ao contexto familiar local.

Público: Estudantes entre o 6 e 9ํanos do Ensino Fundamental.

Primeiro momento: Solicitar que os estudantes pesquisem relatos orais entre os seus familiares sobre a relação estabelecida com os frutos do Cerrado, incluindo informações variadas, desde os aspectos nutricionais, médicos, afetivos etc. Como proposta de investigação, os estudantes podem realizar a seguinte pergunta: De que forma os frutos presentes do Cerrado fazem parte da vida do nosso povo? Os estudantes devem registrar as respostas dos familiares entrevistados.

Segundo momento: Em seguida, na mediação pedagógica em sala de aula, o educador solicita que os estudantes apresentem os resultados de suas pesquisas e comparem suas respostas com as obtidas por outros colegas de classe, a fim de reconhecer os padrões que demarcam o coletivo comunitário sobre essa temática. Ao final da atividade, o educador argumenta com os estudantes sobre a relação entre alimentação quilombola e elementos da biodiversidade do Cerrado.

Terceiro momento: Por fim, organiza-se, entre professores e estudantes, uma exposição, fora da escola, com os frutos que foram citados na fase de entrevistas. Os estudantes podem apresentar às outras turmas, aos professores e aos convidados na comunidade, as aprendizagens construídas no decorrer da atividade, aproveitando para, por meio da oralidade, estabelecer um diálogo entre as aprendizagens nos seus círculos familiares e as formais escolares.

\section{O Coletivo de Pensamento entre Correntes de Educação Ambiental}

Ao compreender os educadores, sujeitos e coparticipantes da pesquisa, como um coletivo de pensamento, imprime-se, nessa intenção, a argumentação de Fleck 
(1986), que entende tal coletivo por meio de um conceito funcional, sendo mais um grupo com concepções similares ou próximas sobre uma mesma temática do que uma classe propriamente dita. É nesse sentido que Delizoicov e Delizoicov (2014) argumentam que, na EA escolar, as origens socioculturais dos sujeitos participantes permitem considerar as categorias Estilo de Pensamento e Coletivo de Pensamento úteis ao processo analítico do campo, pois em resumo tratam-se respectivamente de:

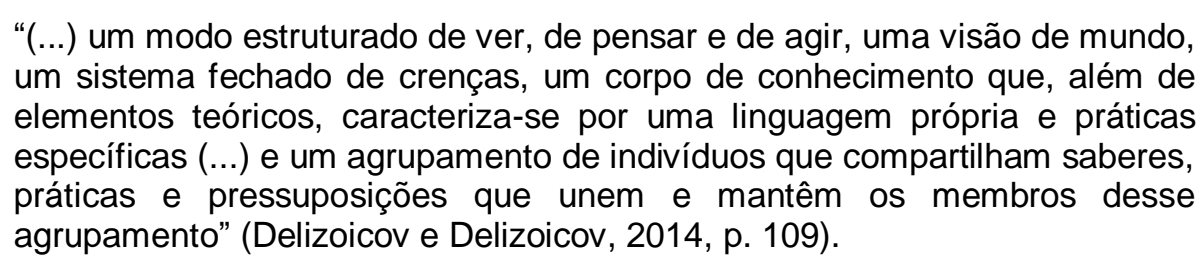

Desse modo, um estilo de pensamento une os integrantes de um coletivo, caracterizando o trabalho por meio da cooperação e da comunicação baseadas na circulação intracoletiva de ideias, quando estes sujeitos compartilham o mesmo estilo de pensamento ou na circulação intercoletiva, quando diferem em seus estilos (Fleck, 1986).

Esse mecanismo de circulação de ideias corresponde a um efeito prático, aplicável, pois o estilo de pensamento passa a direcionar a observação e a ação dos membros do coletivo, redefinindo as relações entre os sujeitos e os objetos sob análise e redefinindo, também, as interações entre os próprios sujeitos (Delizoicov e Delizoicov, 2014), contribuindo para a "instauração, a extensão e a transformação do próprio estilo de pensamento, quando do enfrentamento de problemas cujos estilos construídos historicamente ainda não tem soluções consistentes” (Fleck, 1986). É nesse sentido que sob os problemas relativos ao meio ambiente, a EA CríticoTransformadora pode contribuir na elaboração de uma práxis pedagógica que objetive transformar os estilos de pensamento em um sentido crítico, emancipatório e interdisciplinar.

Ao posicionar os educadores participantes desta pesquisa como um coletivo de pensamento, possuidores de um estilo de pensamento representativo de seu grupo e associado ao seu contexto quilombola/comunitário, descrito no decorrer desse texto, foi possível identificar as correntes de EA (Sauvé, 2004) predominantes, abstraídas a partir da análise textual de suas interlocuções. A seguir, apresenta-se as quatro 
correntes mais frequentes em seus pensamentos/ações com a intenção de favorecer um diálogo entre seus diferentes pressupostos.

É necessário esclarecer que denominamos predominância nas correntes no coletivo de pensamento, aquelas identificadas no discurso dos três professores participantes com uma frequência entre quatro, cinco ou seis ocorrências nos metatextos apresentados. Pela necessidade de generalização do coletivo de pensamento, as correntes que foram identificadas no discurso de apenas um ou dois professores, ou as que estão restritas a uma menor quantidade de temas, não foram consideradas como representantes do coletivo trabalhado, pois podem significar uma tangente particular do pensamento unitarizado de cada educador, que certamente tem seu valor na elaboração curricular da disciplina, mas escapa do potencial totalizador aqui intencionado.

\subsection{Corrente Etnográfica}

“(...) Como a gente vivia. Como os nossos pais foram criados. Como a gente
foi criado. Então essas crianças de hoje, elas não podem sair dessa cultura,
principalmente que são né? Povos... pessoas quilombolas. Então eles não
podem perder essa cultura dessa aprendizagem. (...) (Professor de
Mumbuca, trecho de entrevista semiestruturada).
"(...) Lia na sala com os alunos e nós trabalhava assim, olha aqui: 'fulano falou
isso e isso'. Sempre nós trabalhamos com a realidade, por exemplo, planta
medicinal com Dotôra. A parteira que foi parteira mais de sessenta anos; a
Laurentina, que tá viva. Nós trabalhamos com Diolino que mora ali e ele disse
que tem noventa e cinco e a vó que se tivesse viva tava com cento e poucos
anos e nasceu lá naquele lugar, a fonte era mesma, então a gente trabalhou
isso... foi o conhecimento das pessoas. (...) (Professor do Mumbuca, trecho
de entrevista semiestruturada)."

De acordo com Sauvé (2004), as práticas associadas à corrente etnográfica atribuem especial ênfase ao caráter cultural da relação com o meio ambiente. Dessa forma, a Educação Ambiental pensada sob esse enfoque não impõe uma visão de mundo, mas leva em conta os aspectos culturais das comunidades envolvidas. É nesse sentido que a Corrente Etnográfica interessa-se em adaptar a pedagogia às realidades socioculturais diversas e, em grande medida, inspirar-se nas pedagogias das diferentes culturas que têm uma relação simbólica específica com o meio ambiente. 
Nos diferentes metatextos aqui apresentados, pode-se identificar a relação com esta corrente nas interlocuções dos educadores, quando ocorre: (a) a menção direta ao processo de elaboração da identidade quilombola entre os estudantes na comunidade; (b) o resgate das simbologias comunitárias e práticas associadas aos conhecimentos tradicionais; (c) a participação comunitária nas pesquisas diagnósticas realizadas pelos docentes; assim como, (d) a avaliação sobre a aprendizagem em âmbito familiar sobre os conteúdos associados à nova disciplina.

\subsection{Corrente Práxica}

“(...) Pra melhorar essa disciplina assim (...) a gente precisa mesmo que esse material venha. Tem que juntar alguém, trabalhar em equipe de professores, alguém da Secretaria de Educação e junto organizar o material pra trabalhar. Porque muitas das vezes... você vai pesquisar e aí quando você vai pesquisar você não tem referência. Pesquisar o quê? (...) Então é uma coisa assim que acho que precisa ser produzido material pra eu acho que daqui a uns dois, três anos talvez já tenha o material porque a disciplina foi criada no passado. (...)" (Professor do Mumbuca, trecho de entrevista semiestruturada).

“(...) Eu tive lá no esgoto do Tio Anísio. (...) Muito bonito o esgoto. Eu tive lá e achei o máximo. Eu levei minhas crianças, porque eu não podia levar muitos alunos, mas eu levei os meus. É impressionante como é que é o esgoto, se eu tivesse o privilégio de ir lá outra vez (..) Levava duas professoras pra tá conversando. Você vê assim como é esses... tem uma coisa diferente quando você chega na roça de esgoto e o Anísio seria uma pessoa maravilhosa pra contar. (...)" (Professor do Mumbuca, trecho de entrevista semiestruturada).

Em Sauvé (2004), práxica é a corrente em Educação Ambiental que atribui ênfase na aprendizagem em diálogo com a ação e a melhora desta. Tal aprendizagem convida a comunidade para uma reflexão na ação, no que está em curso, não se tratando somente de elaborar conhecimentos e habilidades com objetivo de realizar ações futuras, mas de lembrar que reflexão e ação retroalimentam-se na configuração da práxis. A dinâmica da reflexão práxica é participativa e envolve diferentes atores em uma mesma situação que necessite ser transformada, a ação pedagógica é acompanhada da pesquisa necessária para operar algum nível de mudança, seja nas pessoas ou no meio ambiente.

Entre os diferentes metatextos, esta corrente associa-se às interlocuções direcionadas (a) ao planejamento de atividades de ensino práticas; (b) à produção de material didático-pedagógico para o trato do componente curricular; (c) às expectativas de transformações sociais e culturais na juventude, mediante ação 
reflexiva sobre sua identidade; assim como (d) à apresentação de uma dinâmica participativa de elaboração curricular, caracterizada pela multiplicidade de vozes do contexto comunitário.

\subsection{Corrente Humanista}

“(...) As veredas que vê as águas, vê o cuidado da água, o cuidado pra não botá fogo, pra não queimar o buritizal. Quando a gente vai pro capim-dourado, a gente tem assim o maior cuidado de deixar a semente, de ter cuidado com a vereda, de dizer que ela faz parte de nós. Essa vereda... nossos antepassados, todo mundo passou por aqui. (...)" (Professor de Mumbuca, trecho entrevista semiestruturada).

“(...) Acho que é um dos maior... quase que um dos maior plantio aqui do Brasil. É projeto né? Então aí eu falei a nossa água que tá... ela tá hoje... ela tá pura... tá purificada, mas nesse projeto aí a água do rio não pode ser mais consumida por quê? Porque o agrotóxico ele é prejudicial, contamina o solo. (...) a pessoa olha no rio tem um peixe e ele pensa que a água tá limpa, mas a água não tá, o peixe tá poluído. (...)" (Professor de Mumbuca, trecho entrevista semiestruturada).

Tal como a corrente etnográfica, a corrente humanista insere-se em contexto de especial ênfase à dimensão humana sobre o meio ambiente, ou seja, no entendimento sobre o cruzamento de natureza e cultura como elaborador das percepções ambientais. O ambiente corresponde a variadas dimensões: históricas, culturais, políticas, econômicas, estéticas etc., portanto, o valor simbólico construído pelas comunidades humanas deve ser levado em conta na sua significação. Da mesma forma, a noção de patrimônio é natural e cultural, ou seja, o elo entre a criação material humana e as possibilidades da natureza. A corrente humanista convoca a observação da paisagem a partir do exame sensorial, sensível e afetivo (Sauvé, 2004).

Da mesma maneira, nos diferentes metatextos, essa corrente de EA articulase quando ocorre (a) a valorização da presença humana sobre o Cerrado; (b) a reconstrução das paisagens locais com um viés memorialístico sobre as migrações dos fundadores da comunidade; e (c) o planejamento de atividades de campo que permitam a observação da paisagem como um aspecto identitário e afetivo sob a intenção de discutir conservação ambiental. 


\subsection{Corrente Conservacionista/Recursista}

“(...) Então assim, é um conjunto, eu acho que faz parte do Cerrado, a gente tem que olhar pro Cerrado e dizer assim 'olha, isso aqui nos contribuiu', não pra nós estragar, queimar, destruir, não. Isso fez parte pra nós tá hoje nesse, aqui hoje no Mumbuca, tinha que ter a natureza, se aqui não tivesse nenhum pau, nenhuma árvore, nós não tinha ficado aqui. (...)" (Professor do Mumbuca, trecho de entrevista semiestruturada).

“(...) eles são importante, o Parque é importante, a natureza é importante, conservar eu acho importantíssimo. Eu sou contra qualquer coisa que fizer com a natureza, cortar um pau, botar fogo, qualquer coisa eu sou contra, por quê? Porque nossos antepassados ficou aqui porque tinha esse mato, tinha essa água, tinha essa fartura de planta, de fruta aqui do Cerrado. (...)" (Professor do Mumbuca, trecho de entrevista semiestruturada).

Em proposições associadas à noção de natureza-recurso, a corrente conservacionista/recursista centra-se na chamada "conservação" tanto em relação à quantidade, quanto na associação com o patrimônio construído; incluindo-se, na perspectiva de patrimônio, os aspectos socioculturais concernentes à humanidade. Dessa forma, a água, o solo, as plantas comestíveis e medicinais, os animais, a cultura, as práticas sociais e produtivas, os usos de biodiversidade etc., fazem parte de um conjunto patrimonial que pode ser conservado; preocupa-se, portanto, com a administração do meio ambiente, a gestão adequada dos recursos naturais e das práticas sociais associadas a eles, visto que os imperativos de ação comportamental individual ou coletiva relacionados à ideia de consumo são edificantes dessa corrente (Sauvé, 2004).

Nas interlocuções produzidas pelos docentes, essa corrente pode ser percebida nos momentos em que (a) diretamente associa-se os saberes ligados à cultura quilombola com o manejo de espécies nativas vegetais; (b) ocorre uma preocupação com a execução correta dos procedimentos associados à atividade agrícola comunitária; (c) discute-se temáticas coletivas ligadas à escassez de determinado recurso ambiental, como o acesso aos recursos hídricos; e (d) associase qualidade de vida com a manutenção de práticas culturais ancestrais.

\section{O saber ambiental emergente da práxis pedagógica histórico-crítica}

Buscamos, no decorrer deste texto, estabelecer uma associação entre a prática pedagógica dos professores e a elaboração de um saber ambiental, articulador das 
dinâmicas socioambientais presentes na interface escola-comunidade. Para isso, prática e teoria não foram encaradas como elementos separados, estabelecendo-se mais que a aplicação da teoria na prática, como preconiza uma perspectiva epistemológica positivista, ou seja, a prática pedagógica não foi encarada simplesmente como uma aplicação de conhecimentos teóricos de diferentes disciplinas científicas. De igual modo, a relação teoria-prática não foi somente entendida como uma troca bidirecional, em que a prática é resultado de um processo que tem início nela mesma, em um processo de retroalimentação, como prevê a perspectiva epistemológica fenomenológica (Caldeira e Zaidan, 2013).

A conceituação de prática pedagógica concebida nesta pesquisa dialoga com a perspectiva epistemológica histórico-crítica, cuja compreensão da realidade dá-se a partir de uma totalidade concreta, ou seja, um todo estruturado, no qual o processo dialético pode permitir a compreensão de um fato ou de conjunto de fatos (Kosik, 1976 apud Caldeira e Zaidan, 2013). Pressupõe-se que tal processo dialético não dá conta de entender essa realidade como um todo acabado, sendo essa a perspectiva em que emerge a consciência da prática em unidade com a teoria, alcançando-se o conceito de práxis: uma atividade teórico-prática, isto é, que possui um aspecto ideal, teórico, do plano das ideias e pensamentos, e um aspecto prático, físico, baseado na experiência (Caldeira e Zaidan, 2013).

Nessa perspectiva, a atividade docente é considerada, portanto,

(...) expressão do saber pedagógico e este como, ao mesmo tempo, fundamento e produto da atividade docente que acontece no contexto escolar, numa instituição social e historicamente construída, a ação docente é compreendida como uma prática social (...) que se constrói no cotidiano dos sujeitos nela envolvidos e que, portanto, nela se constituem como seres humanos (Caldeira e Zaidan, 2013, p. 19).

A atividade docente quando antecipa conscientemente o resultado que se pretende atingir é considerada práxis, ou seja, para que a realidade seja modificada é necessária uma ação prática e esta demanda uma teoria subjacente. A práxis, portanto, contém a ideia e a ação, a unidade entre teoria e prática no objetivo de transformação da realidade, sendo simultaneamente a expressão e a fonte da ação docente, fundamento e produto da atividade que permite um processo contínuo de 
criação e recriação de saberes a partir do cotidiano, em consonância com os limites e possibilidades apresentados pelo contexto (Caldeira e Zaidan, 2013).

Partindo dessa conceituação de práxis e refletindo sobre a perspectiva da pesquisa aqui adotada, é importante perceber que, na análise do cotidiano escolar, deve-se ter em conta que o objetivo central esteja em captar a essência da ação docente, ou seja, considerar que, além da aula como encontro em espaço e tempo determinados, há os aspectos relacionados à formação docente e discente, ao trabalho de planejamento, à cultura do professor e dos estudantes, aos valores da comunidade escolar etc., procurando compreender a relação teoria-prática na vivência escolar cotidiana, repousada na atividade do educador e em suas atribuições enquanto elemento fundamental de análise (Caldeira e Zaidan, 2013).

Nesse contexto de ação docente enquanto práxis, Ruscheinsky (2005) compreende a pesquisa em EA como um inquérito sobre algum fenômeno socioambiental, na intenção de descobrir novas informações, relações e possibilitar a ampliação sobre o conhecimento existente por meio do entrelaçamento com as diferentes histórias orais, os discursos e as possibilidades de ação dos sujeitos envolvidos. A descoberta de significados atribuídos ao real diante do diálogo propositivo pode emergir de metodologias que privilegiem a construção de narrativas e subsidiem o desenvolvimento de experiências em pesquisa qualitativa pelo par interdisciplinar entre patrimônio cultural e educação ambiental (Ruscheinsky, 2005).

Para Jacobi (2013), apesar de as questões ambientais serem globais, em uma comunidade local, as vivências acontecem de forma singular, ou seja, as ações integradas a contextos locais devem ser apropriadas para que as comunidades reconheçam seus problemas e assumam a responsabilidade sobre o seu território, encontrando as respostas para o enfrentamento de suas questões, por meio da criação de novas formas de conhecimento, promotoras de mudanças de valores a partir da elaboração de um saber dialógico, solidário e complexo, que configure novas possibilidades de ação.

Nesse sentido, para a pesquisa em EA, a fonte oral permite abranger uma rede de signos, sentimentos, significados e emoções que, no momento em que são enunciadas em formato discursivo pelo narrador ao pesquisador, na forma de relatos de vida, constituem-se no próprio objeto de estudo, ou seja, o narrador ou sujeito 
entrevistado não é em si o objeto, mas sim a sua realidade experimentada e interpretada, contada subjetivamente sob seu ponto de vista (Ruscheinsky, 2005), vislumbrando uma postura reflexiva em torno da problemática ambiental, tradutora de um conceito de ambiente complexificado e promotora de novas mentalidades, conhecimentos e comportamentos (Morin, 2000 apud Jacobi, 2013).

Nessa articulação,

(...) há que se reconhecer os agentes do espaço social enquanto sujeitos (...) e que o profissional percorra os principais fatos da vida individual e social, bem como tente compreender o horizonte de vida, o significado atribuído aos fenômenos sociais e ambientais pelos setores populacionais em atendimento (Ruscheinsky, 2005. p. 136).

Esse reconhecimento é possível porque os integrantes de uma comunidade possuem uma prática compartilhada e de aprendizagem social potencializada pelas interações entre as pessoas, ou coletivo de pensamento (Fleck, 1986), apoiadas em suas ações e discussões, trocas de informações, que produzem, em seu repertório cultural, experiências e histórias que podem mobilizar a coletividade social para a ação diante de problemas recorrentes e dos modos de lidar com conflitos socioambientais (Jacobi, 2013).

A metodologia da pesquisa elaboradora de histórias orais considera a singularidade dos sujeitos envolvidos, permitindo que estes revelem suas experiências sociais e suas ligações com o meio ambiente enquanto patrimônio (Ruscheinsky, 2005). Os sujeitos entrevistados passam a ser compreendidos como construtores de seu modo de vida e, nesse tipo de pesquisa, encontra-se a possibilidade de identificar os significados essenciais atribuídos pelos sujeitos diante dos fenômenos observados, sendo essencial que os indivíduos participantes expressem a originalidade de sua cosmovisão, pois os depoimentos orais conferem, aos sujeitos, uma centralidade no ato de narrar sua história, posicionando o procedimento de pesquisa como uma forma particular de resgate e preservação de memórias (Ruscheinsky, 2005), já que

(...) diz respeito à visibilidade de padrões culturais, estruturas sociais, nexos políticos, relações sociais e processos históricos, visando aprofundar 0 conhecimento sobre essas esferas por meio de conversas com pessoas sobre a sua experiência e ainda o impacto que estas tiveram na vida de cada um, a partir da memória individual. A realização da tarefa de pesquisa consolida-se em um esteio seguro para a afirmação da identidade sócio histórica; da identidade afirmada pode-se depreender os vestígios de um 
patrimônio cultural não-material, bem como a perspectiva do nexo entre sociedades e bens materiais (Ruscheinsky, 2005, p. 142-143).

Em Zanirato (2009), a definição de patrimônio inclui elementos culturais e naturais que podem ser de ordem material ou imaterial e devem estar integrados a um processo de construção social, de cunho histórico, e associados a um grupo social específico em que possam ser reconhecidos como elemento de sua identidade. Jacobi (2013) alerta para o distanciamento da população na participação social ligada à gestão compartilhada do patrimônio cultural e natural; tal conservação efetiva-se no envolvimento da comunidade que os possui, ou seja, quando do reconhecimento dos valores ecológicos, artísticos, estéticos, históricos etc. que se referem a ele.

Nesse sentido, o patrimônio que está diretamente associado à paisagem torna claro o vínculo identitário de uma população com o seu território, pressupondo que as estratégias de conservação envolvam a participação social direta da população, pois a manutenção do bem propriamente dito mescla-se com a valorização das identidades sociais fundamentadas no aspecto territorial, resgatando memórias, histórias e conhecimentos locais presentes na paisagem, por meio da dialogicidade entre natureza e cultura (Jacobi, 2013).

A pesquisa em educação ambiental que utiliza metodologias com as similaridades descritas, o uso de fontes orais com vistas ao desvelamento da práxis pedagógica, permite descortinar uma defesa sobre patrimônio cultural e natural a partir de um determinado grupo social. Em outras palavras, fundamentar que as atividades tradicionais de uma sociedade sejam compreendidas como patrimônio, e que o trabalho do pesquisador, diante das informações obtidas, parta do conhecimento sobre a micro realidade para a totalidade social, pois a história oral não se esgota na elaboração da narrativa, e sim aponta para um entendimento totalizador da sociedade em questão.

De acordo com o guia Educação Ambiental em Unidades de Conservação (Brasil, 2016), uma ferramenta de apoio para o desenvolvimento de ações de EA nas comunidades escolares em áreas de influência das Unidades de Conservação (UCs), entender os diferentes usos de biodiversidade, culturalmente construídos e historicamente transmitidos permite-nos pensar que as atividades de educação ambiental que são direcionadas aos moradores de Unidades de Conservação 
constituem uma estratégia significativa de possibilitar o engajamento da população na conservação da sociobiodiversidade, natural, cultural e histórica, e no desenvolvimento socioambiental local.

É a vertente crítica e emancipatória que deve prevalecer enquanto prática educativa no interior e no entorno de áreas protegidas, com vistas ao fortalecimento da participação social na gestão da biodiversidade, estimulando o protagonismo das comunidades participantes e valorizando as identidades locais no planejamento e execução de projetos (Brasil, 2016). Novamente, por um viés crítico, Carvalho (2004) entende as formas de EA ligadas às correntes da Educação Popular, emancipatória, transformadora, que revisite criticamente os fundamentos que proporcionam a dominação do ser humano e busque um enfrentamento das desigualdades, opondose pedagógica e politicamente às tendências ditas conservadoras e comportamentais.

Utilizando esse viés contextual e interpretativo, argumenta-se que a práxis pedagógica, em seus âmbitos de pensamento e ação, associada a questões especificas do trato escolar, como aquelas relacionadas à valorização das identidades sociais ou aquelas ligadas às temáticas da sociobiodiversidade nesta pesquisa, encontra-se fundamentada na consolidação do que Leff (2003) denomina complexidade ambiental, ou seja, no processo de reelaboração das identidades como consequência da interação entre os aspectos materiais e simbólicos da cultura, embasado tanto no entrecruzamento de saberes de diferentes posições dialéticas quanto nas ações e reflexões coletivas sob a reapropriação da natureza.

Para Leff $(2001,2003)$, a crise ambiental questiona a racionalidade teórica que legitima o crescimento econômico, mas nega a natureza. Ela é caracterizada como uma crise do conhecimento, ou das formas de apreensão do mundo e de ser no mundo, portanto, a solução para tal crise de civilização passa pela apreensão da complexidade ambiental; configurando-se um conceito de ambiente que reintegre os potenciais da natureza, as externalidades sociais, os saberes subjugados e, de forma geral, a complexidade negada pela racionalidade unidimensional e mecanicista que forjou nossa sociedade.

Abre-se, portanto, uma reflexão sobre as formas de ser, de saber e de conhecer o mundo, devendo-se utilizar de uma pedagogia fomentadora de aprendizagens dialógicas e multiculturais que culminem na formação de sujeitos plurais, capazes de 
atuar no mundo abrindo novas possibilidades de interação de acordo com os valores da democracia e dos princípios de sustentabilidade socioambiental, reconstituindo as identidades através do saber hibridizado na interdisciplinaridade e na transdisciplinaridade (Leff, 2003).

O conceito de ambiente implica, portanto,

(...) além de um equilíbrio entre crescimento econômico e conservação da
natureza, a possibilidade de mobilizar o potencial etnoecológico, a
criatividade cultural e a participação social para construir formas diversas de
um desenvolvimento sustentável, igualitário, descentralizado e
autogestionário, capaz de satisfazer as necessidades básicas das
populações, respeitando sua diversidade cultural e melhorando sua
qualidade de vida (Leff, 2001. p. 86).

Aprender a complexidade ambiental demanda a construção de um saber ambiental, ou seja, uma forma de conhecer que está nas interações de sujeitos e culturas, e nas suas diversas interpretações sobre o mundo e a natureza, implicando uma nova compreensão do mundo, e da complexidade deste, que associa os conhecimentos presentes em cosmologias, mitologias, teorias e os diferentes saberes de cada cultura, com os provenientes das ciências e tecnologias (Leff, 2003, 2011); portanto, o respeito à diversidade étnica assume implicações importantes para estratégias de apropriação e manejo de recursos naturais (Leff, 2001).

Leff (2001) argumenta que a elaboração de uma racionalidade ambiental também passa pela esfera de uma racionalidade cultural, entendida como um sistema ímpar que não se homogeneíze com uma lógica ambiental geral, ou seja, um sistema que produza a integridade de cada cultura em suas práticas produtivas e sociais, no diálogo com o seu entorno geográfico e sob as formas de uso específicos de seus recursos naturais.

Desse modo, o saber ambiental, construído a partir de uma racionalidade ambiental, desestrutura a dicotomia entre sujeito e objeto de conhecimento a fim de incorporar identidades no saber e internalizar subjetividades do ser, sinalizando para efeitos significativos na elaboração de uma pedagogia ambiental, ou pedagogia da complexidade ambiental, em que o ambiente seja entendido como a falta de conhecimento que impulsiona o saber e a reapropriação do mundo (Leff, 2001, 2011).

Tal saber ambiental problematiza a fragmentação e a disciplinarização do conhecimento, com o objetivo de constituir um campo de conhecimentos que 
rearticule as relações sociedade-natureza. Em outras palavras, extrapola as ciências ambientais e suas especializações em enfoques ecológicos tradicionais para se abrir ao campo dos valores éticos, dos conhecimentos práticos e dos saberes tradicionais (Leff, 2011), em um movimento de transformação das ciências por um processo de ambientação interdisciplinar do saber.

Ele parte do saber das comunidades, onde se encontra a consciência sobre as formas de manejo de seus recursos, com suas estruturas simbólicas e o sentido atribuído às suas práticas sociais e produtivas e induz transformações de conhecimento de efeito epistemológico (nos objetos de conhecimento), teóricos (nos paradigmas de conhecimento) e metodológicos (interdisciplinaridade e complexidade), podendo-se construir em torno de cada objeto de conhecimento um saber ambiental específico que, por sua vez, transforma os paradigmas de conhecimento em uma perspectiva construtivista, em constante diálogo com a realidade social (Leff, 2001).

O saber ambiental é, portanto, mais que uma mistura dos saberes atuais ou a interligação de diversas disciplinas para resolver um problema específico. É, sim, uma forma de questionamento dos paradigmas dominantes de produção de conhecimento porque constrói novos objetos interdisciplinares de estudo, com a possibilidade de incorporação desses objetos em programas educacionais interdisciplinares (Leff, 2001, 2011).

É nesse sentido que defende-se a consolidação de uma pedagogia ambiental, inserida entre a pedagogia crítica e o pensamento da complexidade, enquanto prática que entrecruze identidades e saberes, que dialogue conhecimentos científicos e populares e na qual o ser no mundo, em âmbito individual ou coletivo, construa-se na relação com o saber ambiental. Ou seja, que o processo de constituição do ser atravesse o questionamento sobre as suas condições ecológicas de sobrevivência, de sustentabilidade e sobre as bases sociais e políticas da democracia e da justiça (Leff, 2003).

Ao entender que os problemas ambientais são, essencialmente, problemas de conhecimento, atribui-se forte implicação sobre as políticas de transmissão de conhecimento, a educação. Elaborar um saber ambiental para aprender sobre a complexidade ambiental não implica somente aprender fatos novos, mas subsidia a 
preparação pedagógica de reapropriação de conhecimentos do ser no mundo, dos saberes de sua identidade que são continuamente produzidos e incorporados a cada indivíduo, em cada cultura. Aprender o mundo implica que o próprio ser, dialogando com seus sentidos e verdades, volte-se para seu entorno, cultura e história, a fim de recriar e reapropriar-se do mundo por meio do reconhecimento de seu próprio conhecimento (Leff, 2003). 


\section{CONSIDERAÇÕES FINAIS}

"Não sou esperançoso por pura teimosia, mas por um imperativo existencial
e histórico. Não quero dizer, porém, que, porque esperançoso, atribuo à
minha esperança o poder de transformar a realidade e, assim convencido,
parto para o embate sem levar em consideração os dados concretos,
materiais, afirmando que minha esperança basta. Minha esperança é
necessária mas não é suficiente. Ela, só, não ganha a luta, mas sem ela a
luta fraqueja e titubeia. Precisamos da herança crítica, como o peixe
necessita da água despoluída" (Freire, 1992).

O processo de formação profissional, seja no âmbito docente ou no âmbito da pesquisa acadêmica, trata-se de uma motivação inicial posta em prática. É um processo reiterativo que não se sabe exatamente em que momento começa e o quanto ainda se precisa caminhar a partir do ponto presente. Mas, de alguma forma precisa-se reconhecer que tal processo constrói aprendizagens significativas que movimentam as nossas esperanças.

As diferentes fases de desenvolvimento do mestrado possibilitaram-me uma diversidade de compreensões fundamentais associadas à uma formação ampla, continua e integrada, tais como: a) o entendimento sobre o papel da pesquisa com desenho qualitativo e participante, enquanto juízo ético e aspecto formativo dos sujeitos; b) o papel teórico e reflexivo potencializado pelas disciplinas cursadas e trocas discursivas com diferentes sujeitos, pesquisadores de diversas áreas e c) a permanente postura dialógica dispensada àqueles com quem mantive relações de amizade, companheirismo e identificação pessoal e acadêmica.

Sobre o desenho qualitativo e participante da pesquisa, valorizo aqui o estabelecimento da relação de parceria com os professores participantes e a oportunidade de desenvolvimento de um trabalho útil aos meus anseios acadêmicos, e de igual forma, aos seus interesses docentes. A respeito do potencial reflexivo das disciplinas cursadas, reitero aqui a possibilidade de, por meio delas, ter realizado tal imersão na cultura acadêmica, capaz de auxiliar na busca de referencial teórico adequado à pesquisa e estabelecer interações discursivas com outros sujeitos em formação. Por fim, a postura dialógica necessária à elaboração de um saber cujas 
fontes sejam diversas, científicas e tradicionais, coletivas, tratou-se de um exercício constante no decorrer do desenvolvimento do mestrado.

Os esforços implementados durante os diferentes ciclos de atividades realizados, apresentam-se aqui consolidados na discussão articulada entre Educação Ambiental Crítica e Educação Quilombola Popular, sob o pano de fundo da relação com os usos de biodiversidade vegetal por povos tradicionais, das concepções de meio ambiente articuladas com questões políticas, sociais, culturais e econômicas e da elaboração de um saber ambiental complexo, multifacetado e articulador de diferentes formas de saber e ser no mundo. Certamente, os próximos esforços a serem travados nessa discussão inicial, em trabalhos futuros, permanecerão articulados à esperança mobilizadora e recriadora do mundo que nos lembra constantemente o trabalho de Paulo Freire; "(...) não entendo a existência humana e a necessária luta para fazê-la melhor sem esperança e sem sonho. A esperança é necessidade ontológica”. 


\section{REFERÊNCIAS BIBLIOGRÁFICAS}

ANDRÉ, M. E. D. A. Texto, Contexto e Significados: algumas questões na análise de dados qualitativos. Cad. Pesq., São Paulo, v. 45, p. 66-71, 1983.

ANDREOLI, V. Diálogos entre os conhecimentos tradicionais e as práticas conservacionistas da natureza: uma possível abordagem. Sociologia \& Política: I Seminário Nacional Sociologia \& Política UFPR, 2009.

BOGDAN, R. C., BIKLEN, S. K. Investigação qualitativa em educação: Uma introdução à teoria e aos métodos. Coleção Ciências da Educação. Orientada por Maria Teresa Estrela e Albano Estrela, Porto Editora. 1999.

BORGES, S. L., ELOY, L. SCHMIDT, I. B., BARRADAS, A. C. S. e SANTOS, I. A. Manejo de fogo em veredas: novas perspectivas a partir dos sistemas agrícolas tradicionais no Jalapão. Ambiente \& Sociedade, Vol. 19 no. 3 São Paulo, 2016.

BOURDIEU, P. Lições de aula. São Paulo: Editora Ática, 2001.

,P. Os usos sociais da ciência: por uma sociologia clínica do campo científico. São Paulo: Editora UNESP, 2004.

BRASIL, Lei de Diretrizes e Bases - Lei 9394/96 | Lei no 9.394, de 20 de dezembro de 1996. Estabelece as diretrizes e bases da educação nacional.

, Política Nacional de Educação Ambiental, 1999 - BRASIL. Lei no 9.795, de

27 de abril de 1999. Dispõe sobre a educação ambiental, institui a Política Nacional de Educação Ambiental e dá outras providências. , Ministério da Educação. Secretaria de Educação Fundamental. Parâmetros Curriculares Nacionais: Ciências Naturais $\left(1^{\circ}\right.$ e $2^{\circ}$ ciclos do ensino fundamental). v. 3. Brasília: MEC, 1997.

, Ministério da Educação. Secretaria de Educação Fundamental. Parâmetros Curriculares Nacionais: Ciências Naturais ( $3^{\circ}$ e $4^{\circ}$ ciclos do ensino fundamental). Brasília: MEC, 1998. , Ministério da Educação. Secretaria de Educação Média e Tecnológica. Parâmetros Curriculares Nacionais (Ensino Médio). Brasília: MEC, 2000. . Lei n. 10.172, de 9/1/2001. Estabelece o Plano Nacional de Educação. Diário Oficial da União, Brasília, DF, 10 jan. 2001.

Presidência da República. Casa Civil. Subchefia para Assuntos Jurídicos. Decreto no 4.887, de 20 de Novembro de 2003. 2003a.

. Lei no 10639, de 9 de janeiro de 2003. Diário Oficial [da] República Federativa do Brasil. Brasília, DF, 9 jan. 2003b.

. Conselho Nacional de Educação. Parecer CNE/CP 3/2004. Diretrizes curriculares nacionais para a educação das relações étnico-raciais e para o ensino de história e cultura afro-brasileira e africana. Brasília, 2004a.

. Conselho Nacional de Educação. Resolução CNE/CP 1/2004. Diretrizes curriculares nacionais para a educação das relações étnico-raciais e para o ensino de história e cultura afrobrasileira e africana. Brasília, 2004b.

. Diretrizes Curriculares Nacionais para a Educação Escolar Quilombola: algumas informações. Câmara de Educação Básica do Conselho Nacional de Educação (CNE). Brasília - DF/2011.

, Educação Ambiental em Unidades de Conservação. Ações voltadas para comunidades escolares no contexto da gestão pública da biodiversidade. 2016. 
BRITO, A. X.; LEONARDOS, A. C. A identidade das Pesquisas Qualitativas: construção de um quadro analítico. Caderno de Pesquisas, n. 113, p. 7-38, 2001.

CALDEIRA, A. M. S.; ZAIDAN, S. Práxis pedagógica: um desafio cotidiano. Paidéia r. do cur. de ped. da Fac. de Ci. Hum., Soc. e da Saú., Univ. Fumec Belo Horizonte Ano 10 n. 14 p. 15-32, 2013.

CAPRA, F. A Teia da Vida. São Paulo: Cultrix. 1997.

CARVALHO, I. C. de M. Educação ambiental: a formação do sujeito ecológico / Isabel Cristina de Moura Carvalho - São Paulo: Cortez, 2004.

CASCINO, F. Educação ambiental: princípios, história, formação de professores / Fabio Cascino. São Paulo : Editora Senac São Paulo, 1999.

CONDÉ, M. L. L. (Org.) Ludwik Fleck: estilos de pensamento na ciência. Belo Horizonte: Fino Traço, 2012.

DELIZOICOV, D.; DELIZOICOV, N. C. Educação Ambiental na escola. IN: Educação Ambiental : dialogando com Paulo Freire / Carlos Frederico Bernardo Loureiro, Juliana Rezende Torres, (orgs.). - 1. ed. - São Paulo : Cortez, 2014.

DIAS, L. R. Quantos passos já foram dados? A questão de raça nas leis educacionais. Da LDB de 1961 à Lei 10.639 de 2003. IN: História da Educação do Negro e outras histórias/Organização: Jeruse Romão. Secretaria de Educação Continuada, Alfabetização e Diversidade. - Brasília: Ministério da Educação, Secretaria de Educação Continuada, Alfabetização e Diversidade, 2005.

DUARTE, R. Pesquisa qualitativa: Reflexões sobre o trabalho de campo. Cadernos de Pesquisa, n. 115, p. 139-154, 2002.

ESTEBAN, M. P. S. Pesquisa Qualitativa em Educação: fundamentos e tradições. Porto Alegre: AMGH, 268p., 2010.

FALEIRO, R.P. Relatório de Técnico-Científico do Levantamento Espeleológico. In Jalapão: Expedição Científica e Conservacionista (M. B. Arruda e M. von Behr orgs.). IBAMA, Brasília, p.51-81. 2002.

FIGUEIREDO, O. V. A. Política Educacional e a Questão Racial Brasileira. Dissertação de mestrado. Universidade Estadual de Feira de Santana. 2010.

FREIRE, P. Pedagogia do oprimido. Rio de Janeiro : Paz e Terra. 218p.,1987.

P. Pedagogia da Esperança: Um reencontro com a Pedagogia do Oprimido / Paulo Freire. Rio de Janeiro : Paz e Terra, 1992.

,P. Pedagogia da autonomia: saberes necessários à prática educativa / Paulo Freire. - São Paulo : Paz e Terra, 1996.

FLECK, L. La génesis y el desarrollo de un hecho científico: introducción a la teoría del estilo de pensamiento y del colectivo de pensamiento. Madri: Alianza, 200p.,1986.

GADOTTI, M. Educação Popular, Educação Social, Educação Comunitária: Conceitos e Práticas Diversas, Cimentadas por uma causa comum. Revista Diálogos: Pesquisa em extensão universitária. IV Congresso Internacional de Pedagogia Social: domínio epistemológico. Brasília, v. 18, n. 1, 2012.

GIANOTTEN, V.; WIT, T. Pesquisa participante em um contexto da economia camponesa. In: BRANDÃO, C. R. (Org.). 4. reimpr. Repensando a pesquisa participante. São Paulo: Brasiliense, p. 158-188, 2010. 
GRACIANI, G. D. A função social da escola pública brasileira: um estudo exploratório. 2015. Dissertação (Mestrado em Educação) - Faculdade de Educação, Universidade de São Paulo, São Paulo, 2015.

GUIMARÃES, M. Armadilha paradigmática na educação ambiental. IN: Pensamento complexo, dialética e Educação Ambiental / Carlos Frederico B. Loureiro, Philippe Pomier Layrargues, Ronaldo Souza de Castro (Orgs.), - São Paulo : Cortez, 2006.

JACOBI, P. Governança Ambiental e Práticas Participativas. IN: Aprendizagem social e unidades de conservação: aprender juntos para cuidar dos recursos naturais./ coordenador, Pedro Roberto Jacobi.; coordenadores editoriais, Luciana Yokoyama Xavier e Marcelo Takashi Misato. - São Paulo: IGEE/PROCAM, 96 p., 2013.

LAYRARGUES, P. P.; LIMA, G. F. da C. Mapeando as macro-tendências políticopedagógicas da educação ambiental contemporânea no Brasil. VI Encontro "Pesquisa em Educação Ambiental". A Pesquisa em Educação Ambiental e a Pós-graduação no Brasil. Ribeirão Preto, 2011.

LAYRARGUES, P. P. Para onde vai a Educação Ambiental? O cenário políticoideológico da Educação Ambiental brasileira e os desafios de uma agenda política crítica contra-hegemônica. Revista Contemporânea de Educação, vol. 7, n. 14, 2012.

LEFF, E. Saber ambiental: sustentabilidade, racionalidade, complexidade, poder / Enrique Leff . Tradução de Lúcia Mathilde Endlich Orth - Petrópolis, RJ : Vozes, 2001.

,E. Pensar a Complexidade Ambiental. IN: A complexidade ambiental / Enrique Leff, (coord.) ; tradução de Eliete Wolff. - São Paulo : Cortez, 2003.

,E. Complexidade, Interdisciplinaridade e Saber Ambiental. Olhar de Professor, Ponta Grossa, v. 14, n. 2, p. 309-335, 2011.

LEITE, I. B. O quilombo no Brasil: questões conceituais e normativas. Florianópolis: NUER/UFSC. 2000.

LORENZETTI, L.; DELIZOICOV, D. Estilos de Pensamento em Educação Ambiental: Uma Análise a partir das dissertações e teses. VII ENPEC. Encontro Nacional de Pesquisa em Educação em Ciências. Florianópolis, 2009.

LORENZETTI, L., MUENCHEN, C.; e SLONGO, I. I. P. A Contribuição epistemológica de Ludwik Fleck na produção acadêmica em educação em ciências. VIII ENPEC. Encontro Nacional de Pesquisa em Educação em Ciências, 2011.

LUDKE, M.; ANDRÉ, M. E.D.A. Pesquisa em educação: abordagens qualitativas. São Paulo, Editora Pedagógica e Universitária, 99p., 1986.

MACHADO, E. M. Pedagogia Social no Brasil: Políticas, Teorias e Práticas em Construção. IX Congresso Nacional de Educação - EDUCERE. II Encontro Sul Brasileiro de Psicopedagogia. PUCPR, 2009.

MACHADO, E. R.; RODRIGUES, M. de F.; SEVERO, J. L. R. de L. Pedagogia, Pedagogia Social e Educação Social no Brasil: Entrecruzamentos, Tensões e Possibilidades. Interfaces Científicas - Educação - Aracaju. V.3. n. 1 p.11 20, 2014.

MORAES, R.; GALIAZZI, M. do C. Análise textual discursiva / Roque Moraes, Maria do Carmo Galiazzi. - ljuí : Ed. Unijuí, - 224 p., 2007. 
MORIN, E. Complexidade e ética da solidariedade. In CASTRO, G. et al. Ensaios de complexidade. Porto Alegre: Sulina, 1997.

, E. A cabeça bem feita. Repensar a reforma, reformar o pensamento. Trad. Eloá Jacobina. Rio de Janeiro: Bertrand Brasil, 2000.

NASCIMENTO, A. Quilombismo. Petrópolis: Vozes, 1980.

NATURATINS, Secretaria do Meio Ambiente e Recursos Hídricos do Tocantins. Parque Estadual do Jalapão. Acesso em abril de 2019. Disponível em < http://gesto.to.gov.br/uc/45/>

NUNES, G. H. L. Introdução: Educação Quilombola. In: Orientações e Ações para a Educação das Relações Étnico- Raciais. Brasília: SECAD, p. 139-161, 2006.

RUSCHEINSKY, A. A pesquisa em história oral e a produção de conhecimento em educação ambiental. IN: Educação Ambiental: pesquisa e desafios / organizado por Michèle Sato e Isabel Cristina Moura Carvalho. - Porto Alegre : Artmed, 2005.

SAUVÉ, L. Una Cartografía De Corrientes En Educación Ambiental. In Sato, Michèle, Carvalho, Isabel (Orgs). A pesquisa em educação ambiental: cartografias de uma identidade narrativa em formação. Porto Alegre: Artmed, 2004.

SAUVÉ, L. Educação Ambiental: possibilidades e limitações. Educação e Pesquisa, São Paulo, v. 31, n. 2, p. 317-322, 2005.

SEPLAN - Secretaria do Planejamento e Meio Ambiente do Estado de Tocantins. Plano de Manejo do Parque Estadual do Jalapão. Palmas: Seplan, 132 p., 2003.

SCHMIDT, M. L. S. Pesquisa Participante: Alteridade e Comunidades Interpretativas. Psicologia USP, 17(2), 11-41, 2006.

SCHMITT, A., TURATTI, M. C. M.; e CARVALHO, M. C. P. de. A atualização do conceito de quilombo: identidade e território nas definições teóricas. Ambiente \& Sociedade - Ano V - № 10, 2012.

SILVA, G. da.; e ARAÚJO, M. Da Interdição escolar às ações educacionais de sucesso: escolas dos movimentos negros e escolas profissionais, técnicas e tecnológicas. IN: História da Educação do Negro e outras histórias/Organização: Jeruse Romão. Secretaria de Educação Continuada, Alfabetização e Diversidade. - Brasília: Ministério da Educação, Secretaria de Educação Continuada, Alfabetização e Diversidade, 2005.

SILVA, P. B. G. e. Aprender, Ensinar e Relações Étnico-raciais no Brasil. Educação. Porto Alegre/RS, ano XXX, n. 3 (63), p. 489-506, 2007.

SILVA. D. J. da; FERNANDEZ, C.; PAIVA, J. ARAÚJO, M.; VÂNIA, S. Educação Quilombola: Um Direito a ser Efetivado. Edição: Centro de Cultura Luiz Freire e Instituto Samaúma, 2008.

SILVA, R da. Limites e Possibilidades do Direito à Educação na Legislação Educacional Brasileira. Voos. Revista Polidisciplinar Eletrônica da Faculdade de Guairacá. Volume 02 Ed. 01, 2010.

SILVA, R. da. O Domínio Sociocultural da Educação Social Brasileira e a Tradição da Animação Sociocultural. In: SILVA, Odair Marques et al. Pedagogia Social: Animação Sociocultural Um Propósito da Educação Social. São Paulo: Expressão e Arte, p.41-42, 2012.

SILVA, T. R. da. O direito à Educação da População Negra e Analfabeta em Territórios de Maioria Afrodescendente. XXI Simpósio Brasileiro de Política e 
Administração da Educação. ANPAE. Associação Nacional de Política e Administração da Educação, 2013.

SILVA, A. F. G.; e PERNAMBUCO, M. M. C. A. Paulo Freire: Uma proposta pedagógica ético-crítica para a Educação Ambiental. IN: Educação Ambiental: dialogando com Paulo Freire / Carlos Frederico Bernardo Loureiro, Juliana Rezende Torres, (orgs.). - 1. ed. - São Paulo : Cortez, 2014.

SORRENTINO, M.; MENDONÇA, R. T. P.; FERRARO J. R. Educação Ambiental como política pública. Educação e Pesquisa, São Paulo, v. 31, n.2, p. 285299, 2005.

TORRES, J. R., FERRARI, N. MAESTRELLI, S. R. P. A Educação Ambiental Crítico - Transformadora no contexto escolar: teoria e prática freireana. IN: Educação Ambiental : dialogando com Paulo Freire / Carlos Frederico Bernardo Loureiro, Juliana Rezende Torres, (orgs.). - 1. ed. - São Paulo : Cortez, 2014.

VIANA, R. Diálogos possíveis entre saberes científicos e locais associados ao capimdourado e ao buriti na região do jalapão, TO. 92 pp. Dissertação (Mestrado) Instituto de Biociências da Universidade de São Paulo. Departamento de Botânica, 2013.

ZANIRATO, S. H. Usos sociais do patrimônio cultural e natural. Patrimônio e Memória. UNESP - FCLAs - CEDAP, v. 5, n.1, p. 137-152, 2009. 


\section{RESUMO}

A Educação Ambiental (EA) é entendida como o processo pelos quais indivíduos e coletividades constroem valores sociais, conhecimentos, habilidades, atitudes e competências voltadas para a conservação do meio ambiente. Nesse sentido, há que se pensar sobre qual a melhor abordagem de EA almeja-se construir, a depender dos contextos apresentados. Dessa forma, pensar a EA em um cenário peculiar de comunidades tradicionais é uma tarefa que exige condições particulares do pesquisador, já que a relação sociedade-natureza não se configura somente como um estudo das Ciências Biológicas, mas articula todos os ramos das ciências, incluindo as Ciências Sociais, permitindo o diálogo entre conhecimento científico e conhecimento tradicional de forma transdisciplinar. Nesta pesquisa, procurou-se discutir a EA em um contexto formal de ensino, estabelecendo um diálogo entre as questões identitárias e as socioambientais presentes na comunidade do Mumbuca, Jalapão (TO), tendo como ponto de partida a inserção de um novo componente curricular, "Saberes e Fazeres Quilombolas", ao Ensino Fundamental da escola comunitária. Por meio da pesquisa qualitativa e participativa, foram realizadas entrevistas semiestruturadas com três professores, observação participante da vida em comunidade e análise textual-discursiva do corpus textual obtido durante as atividade de campo. Os resultados estão organizados em um conjunto de (a) seis metatextos temáticos que ilustram questões importantes discutidas com os professores da escola e (b) seis planos de atividades de ensino, que demonstram a possibilidade de associação da rotina escolar com a vida comunitária. Entende-se os professores como um coletivo, portador de determinado estilo de pensamento, e discute-se as associações entre seus discursos e as correntes de EA, assim como a emergência da noção de um saber ambiental associada à práxis pedagógica docente articuladora entre Educação Ambiental Crítica e Educação Quilombola Popular.

Palavras-chave: Educação Ambiental, Educação Quilombola, Saber Ambiental, Diálogo de Saberes, Jalapão. 


\section{ABSTRACT}

Environmental Education (EE) is understood as the process by which individuals and collectivities construct social values, knowledge, skills, attitudes and competences directed towards the conservation of the environment. In this sense, it is necessary to think about what the best approach of EE that we wish to elaborate, depending on the contexts presented. Thus, to think of EE in a peculiar setting of traditional communities is a task that demands particular conditions of the researcher, since the relation society-nature is not only a study of the Biological Sciences, but articulates all the branches of the sciences, including the Social Sciences, allowing the dialogue between scientific knowledge and traditional knowledge in a transdisciplinary way. In this research, we sought to discuss EE in a formal teaching context, establishing a dialogue between the identity and socio-environmental issues present in the community of Mumbuca, Jalapão (TO), starting with the insertion of a new curricular component "To know and to Do Quilombolas", to the Elementary School of the village community school. Through the qualitative and participative research, semistructured interviews were conducted with three teachers, participatory observation of community life and textual discursive analysis of the textual corpus obtained during field activities. The results are organized into a set of (a) six thematic metatexts that illustrate important issues discussed with school teachers and (b) six teaching activity plans that demonstrate the possibility of linking school routine to community life. The teachers were understood as a collective, carrier of a certain style of thought, and the associations between their discourses and the currents of EE are discussed, as well as the emergence of the notion of an environmental knowledge associated with pedagogical praxis linking Critical Environmental Education and Popular Quilombola Education.

Key words: Environmental Education, Quilombola Education, Environmental Knowledge, Dialogue of Knowledge, Jalapão. 


\section{ANEXOS}

\section{Protocolo de Ética na Pesquisa}

As orientações de cunho ético desta pesquisa são estabelecidas a partir dos princípios presentes (a) no Código Internacional de Ética da International Society of Ethnobiology 4 (Internacional Society of Ethnobiology, 2006), que fornecem uma base teórica para a tomada de decisões a fim de guiar a conduta em pesquisas etnobiológicas, fomentando um compromisso de colaborações significativas e responsabilidade recíproca por todas as partes; (b) no Código de Ética da USP5 Resolução no 4871, de 22 de outubro de 2001, criado para nortear as relações humanas no interior da universidade, remetendo a Declaração Universal dos Direitos Humanos (1948) como documento que alcançou consenso internacional; e (c) nos Padrões Éticos na Pesquisa em Educação da Faculdade de Educação da USP ${ }^{6}$ (FEUSP 2006), cujos princípios assim como os presentes no item (b) são derivados das Declarações e Convenções sobre Direitos Humanos, da Constituição Federal de 1988 e dos compromissos firmados pela Associação Internacional de Universidades.

\section{i. Os sujeitos da pesquisa}

A pesquisa envolve diretamente três (3) educadores adultos da Escola Silvério Ribeiro Matos, localizada na Comunidade do Mumbuca na região do Jalapão, Tocantins. A participação é voluntária e não haverá, em nenhuma hipótese, prejuízo caso as pessoas envolvidas optem por não participar da pesquisa ou por dela se retirar a qualquer momento do cronograma de trabalho.

ii. Colaboração dos educadores na pesquisa

O desenho metodológico de pesquisa qualitativa aqui intencionado objetiva dizer que toda a investigação será realizada com a participação ativa dos sujeitos envolvidos, desde a elaboração das questões de pesquisa até a aplicação ou divulgação dos resultados finais, garantindo a comunicação efetiva entre os sujeitos participantes e o pesquisador, além da integridade cultural dos colaboradores. iii. Termo de Consentimento Livre e Esclarecido

\footnotetext{
${ }^{4}$ Disponível em: $<$ http://www.ethnobiology.net/wp-content/uploads/ISECodeofEthics_Portuguese.pdf $>$

${ }^{5}$ Disponível em: $\langle$ http://www.leginf.usp.br/?resolucao=resolucao-no-4871-de-22-de-outubro-de-2001 $>$

${ }^{6}$ Disponível em: $<\underline{\text { http://www3.fe.usp.br/pgrad/PDF_SWF/Documento_Comite de Etica.pdf> }}$
} 
A pesquisa ocorrerá com o consentimento livre e esclarecido dos sujeitos participantes e seguirá as observações discriminadas no documento anexo referente a este termo, sendo necessário que ele seja construído coletivamente em linguagem clara e acessível aos participantes, seguido de assinatura para validação do consentimento.

Cada participante ficará com uma cópia do termo sob sua guarda e deve ficar esclarecido para cada um dos sujeitos (a) os possíveis ônus e benefícios decorrentes da pesquisa para o contexto escolar/comunitário, (b) a justificativa da escolha do objeto de pesquisa e (c) a relevância da pesquisa para o cenário escolar apresentado. Não obstante a isso, no texto apresentado no referido termo, deve estar explícito (a) o caráter voluntário do consentimento, sem prejuízo em declínio de participação; (b) o caráter confidencial das informações obtidas em campo e (c) o anonimato dos sujeitos da pesquisa diante das divulgações decorrentes dos resultados.

iv. Uso de imagens

Havendo necessidade de uso de imagens na elaboração dos materiais de divulgação, estas deverão ser previamente autorizadas pelos participantes.

v. Retorno dos resultados aos participantes

Todos os resultados da pesquisa de interesse aos sujeitos participantes serão disponibilizados aos mesmos e divulgados na Escola Silvério Ribeiro de Matos para a comunidade escolar, em forma e linguagem clara compatível com a realidade social e cultural de docentes, demais funcionários e estudantes. Além disso, cada educador participante receberá uma cópia da dissertação produzida.

vi. Autoria

Todos as publicações e materiais resultantes desta pesquisa são de autoria e sob a responsabilidade dos pesquisadores, resguardados os devidos agradecimentos e o reconhecimento pela participação aos membros da comunidade. 


\section{Termo de Consentimento Livre e Esclarecido}

Concordo em participar, como voluntário, do projeto de pesquisa ao nível de mestrado intitulado "Educação Ambiental no Contexto de Comunidades Extrativistas de Capim-Dourado e Buriti na Região do Jalapão/TO" realizado pelo pesquisador Ronaldo Andrade dos Santos, discente do Programa de Pós-graduação em Ciências Biológicas do Instituto de Biociências (IB) da Universidade de São Paulo (USP), orientando do Professor Dr. Paulo Takeo Sano. Como combinado, o pesquisador se compromete em assumir uma postura ética diante do andamento da pesquisa e dos sujeitos envolvidos com ela, seus contatos por E-mail são rasantos@usp.br e biologoandrade@gmail.com; telefones: (91) 983932158 e (11) 964882358.

Este projeto de pesquisa tem um viés colaborativo-participativo em que os sujeitos envolvidos participam do seu processo de produção, de forma que suas questões de pesquisa principais são (1) investigar como inserção da disciplina "Saberes e Fazeres Quilombolas" pode contribuir para a promoção de aprendizagens relacionadas ao meio ambiente de forma interdisciplinar, e (2) o(a)s professore(a)s, público alvo do projeto, assumem que papel na consolidação de práticas educativas que articulem os novos conteúdos com questões ambientais locais.

Minha participação consistirá, principalmente, em participar dos momentos de planejamento e entrevistas e/ou dos grupos de discussão relacionados à inserção da disciplina. Compreendo que os estudos tem finalidade de pesquisa e que os dados obtidos serão divulgados preservando a minha identidade e assegurando a minha privacidade. Compreendo também que posso não participar da pesquisa quando quiser, se me sentir desconfortável em algum momento da mesma.

Nome e assinatura

Local e data

\footnotetext{
${ }^{7}$ A divergência apresentada entre os títulos do trabalho, visível no Termo de Consentimento Livre e Esclarecido e na dissertação submetida à análise, deu-se em decorrência da necessidade de adequação aos resultados e à discussão realizados, e foi um pressuposto do exercício teórico-metodológico presente na pesquisa.
} 


\section{Protocolo para Notas de Campo}

O protocolo para notas de campo utilizado encontra-se adaptado a partir Bogdan e Biklen (2006) e compreende uma parte descritiva e outra reflexiva, sistematicamente apresentadas abaixo:

I. Identificação inicial:

- Data, hora, nomes dos sujeitos envolvidos, local e numeração da nota.

II. Fase descritiva:

- Retratos do sujeitos envolvidos;

- Reconstrução de diálogos com os participantes;

- Descrição do espaço físico onde o evento foi observado;

- Relato de outros acontecimentos particulares a observação principal;

- Descrição das atividades desenvolvidas;

III. Fase reflexiva:

- Reflexões sobre a análise;

- Reflexões sobre o método;

- Reflexões sobre conflitos e dilemas;

- Reflexões sobre o ponto de vista do observador;

- Pontos de clarificação. 


\section{Estrutura básica do componente curricular}

AGRICULTURA QUILOMBOLA: 1ํANO ENSINO FUNDAMENTAL

\begin{tabular}{|l|l|}
\hline BIMESTRES & $\begin{array}{l}\text { CONTEÚDOS BÁSICOS - 1 ANO - } \\
\text { A IDENTIDADE QUILOMBOLA }\end{array}$ \\
\hline $1^{\circ}$ BIMESTRE & $\begin{array}{l}\text { O eu, filho de quilombola; } \\
\text { A família, de quilombola; }\end{array}$ \\
\hline $2^{\circ}$ BIMESTRE & $\begin{array}{l}\text { A comunidade da agricultura } \\
\text { quilombola; }\end{array}$ \\
\hline $3^{0}$ BIMESTRE & $\begin{array}{l}\text { Agricultura quilombola; } \\
4^{0} \text { BIMESTRE }\end{array}$ \\
& $\begin{array}{l}\text { Animais e plantações da Comunidade } \\
\text { Quilombola; } \\
\text { Lazer/Diversão da Comunidade } \\
\text { Quilombola. }\end{array}$ \\
\hline
\end{tabular}

AGRICULTURA QUILOMBOLA: $2^{\circ}$ ANO ENSINO FUNDAMENTAL

\begin{tabular}{|l|l|}
\hline BIMESTRES & $\begin{array}{l}\text { CONTEÚDOS BÁSICOS }-2^{\circ} \text { ANO - } \\
\text { O AMBIENTE }\end{array}$ \\
\hline $1^{\circ}$ BIMESTRE & $\begin{array}{l}\text { A propriedade da família; } \\
\text { Os rios da região; }\end{array}$ \\
\hline $2^{\circ}$ BIMESTRE & $\begin{array}{l}\text { Vegetação nativa; } \\
\text { Queimadas na região; }\end{array}$ \\
\hline $3^{\circ}$ BIMESTRE & $\begin{array}{l}\text { Importância da chuva; } \\
\text { Desmatamento; }\end{array}$ \\
\hline $4^{0}$ BIMESTRE & O desequilíbrio climático. \\
\hline
\end{tabular}

AGRICULTURA QUILOMBOLA: 3 ANO ENSINO FUNDAMENTAL

\begin{tabular}{|l|l|}
\hline BIMESTRES & $\begin{array}{l}\text { CONTEÚDOS BÁSICOS - } 3^{\circ} \text { ANO - } \\
\text { O TRABALHO NA COMUNIDADE } \\
\text { QUILOMBOLA }\end{array}$ \\
\hline $1^{\circ}$ BIMESTRE & Agricultura quilombola; \\
\hline
\end{tabular}




\begin{tabular}{|l|l|}
\hline $2^{\circ}$ BIMESTRE & $\begin{array}{l}\text { Artesanato local; } \\
\text { Caça e pesca na região; }\end{array}$ \\
\hline $3^{\circ}$ BIMESTRE & $\begin{array}{l}\text { Extrativismo na comunidade; } \\
\text { Os tipos de trabalho na comunidade; }\end{array}$ \\
\hline $4^{\circ}$ BIMESTRE & $\begin{array}{l}\text { A produção da agricultura } \\
\text { quilombola. }\end{array}$ \\
\hline
\end{tabular}

AGRICULTURA QUILOMBOLA: 4ำ ANO ENSINO FUNDAMENTAL

\begin{tabular}{|l|l|}
\hline BIMESTRES & $\begin{array}{l}\text { CONTEÚDOS BÁSICOS - 4 ANO - } \\
\text { INTRODUÇÃO A AGRICULTURA } \\
\text { ORGÂNICA }\end{array}$ \\
\hline $1^{\circ}$ BIMESTRE & $\begin{array}{l}\text { Matéria orgânica; } \\
\text { Composteira doméstica; }\end{array}$ \\
\hline $2^{\circ}$ BIMESTRE & $\begin{array}{l}\text { Adubos orgânicos; } \\
\text { Microrganismo do solo; }\end{array}$ \\
\hline $3^{\circ}$ BIMESTRE & $\begin{array}{l}\text { Fruticultura orgânica; } \\
\text { Olericultura orgânica; }\end{array}$ \\
\hline $4^{\circ}$ BIMESTRE & $\begin{array}{l}\text { Importância econômica dos alimentos } \\
\text { orgânicos; } \\
\text { Cuidados com a alimentação. }\end{array}$ \\
\hline
\end{tabular}

AGRICULTURA QUILOMBOLA: 5 ANO ENSINO FUNDAMENTAL

\begin{tabular}{|l|l|}
\hline BIMESTRES & $\begin{array}{l}\text { CONTEÚDOS BÁSICOS - 50 ANO - } \\
\text { INTRODUÇÃO AO SISTEMA DE } \\
\text { CRIAÇÃO ANIMAL }\end{array}$ \\
\hline $1^{\circ}$ BIMESTRE & $\begin{array}{l}\text { Criação de animal na região; } \\
\text { (Pequeno porte, médio porte e } \\
\text { grande porte) }\end{array}$ \\
\hline $2^{\circ}$ BIMESTRE & $\begin{array}{l}\text { Cadeia produtiva da carne; } \\
\text { (pequeno porte, médio porte e } \\
\text { grande porte) }\end{array}$ \\
\hline
\end{tabular}




\begin{tabular}{|l|l|}
\hline $3^{\circ}$ BIMESTRE & $\begin{array}{l}\text { Cadeia produtiva do leite; } \\
\text { (Cabras, ovelhas e vacas) }\end{array}$ \\
\hline $4^{\circ}$ BIMESTRE & $\begin{array}{l}\text { Geração de renda com animais de } \\
\text { pequeno porte (codorna, galinha, } \\
\text { galinha d'angola, pato) } \\
\text { Principais doenças que acometem os } \\
\text { animais. }\end{array}$ \\
\hline
\end{tabular}

AGRICULTURA QUILOMBOLA: 6ANO ENSINO FUNDAMENTAL

\begin{tabular}{|l|l|}
\hline BIMESTRES & $\begin{array}{l}\text { CONTEÚDOS BÁSICOS - 6 ANO - } \\
\text { INTRODUÇÃO AO SISTEMA DE } \\
\text { PRODUÇÃO VEGETAL }\end{array}$ \\
\hline $1^{\circ}$ BIMESTRE & $\begin{array}{l}\text { O solo agrícola; } \\
\text { Cobertura do solo; }\end{array}$ \\
\hline $2^{\circ}$ BIMESTRE & $\begin{array}{l}\text { Produção agrícola da região; } \\
\text { Principais doenças que acometem a } \\
\text { produção agrícola; }\end{array}$ \\
\hline $3^{\circ}$ BIMESTRE & $\begin{array}{l}\text { Defesa Sanitária Vegetal do } \\
\text { Tocantins; } \\
\text { Silvicultura: produção de mudas; }\end{array}$ \\
\hline $4^{\circ}$ BIMESTRE & $\begin{array}{l}\text { A importância da Biodiversidade } \\
\text { vegetal. }\end{array}$ \\
\hline
\end{tabular}

AGRICULTURA QUILOMBOLA: 7ำ ANO ENSINO FUNDAMENTAL

\begin{tabular}{|l|l|}
\hline BIMESTRES & $\begin{array}{l}\text { CONTEÚDOS BÁSICOS - } 7^{\circ} \text { ANO - } \\
\text { AGROECOLOGIA }\end{array}$ \\
\hline $1^{\circ}$ BIMESTRE & $\begin{array}{l}\text { Manejo e conservação do solo e da } \\
\text { água; } \\
\text { Sistema agroflorestal; }\end{array}$ \\
\hline $2^{\circ}$ BIMESTRE & $\begin{array}{l}\text { Plantio consorciado; } \\
\text { Rotação de culturas; }\end{array}$ \\
\hline
\end{tabular}




\begin{tabular}{|l|l|}
\hline $3^{\circ}$ BIMESTRE & $\begin{array}{l}\text { Manejo do mato e alternância de } \\
\text { capina; } \\
\text { Adubação verde; }\end{array}$ \\
\hline $4^{\circ}$ BIMESTRE & Agricultura Sustentável. \\
\hline
\end{tabular}

AGRICULTURA QUILOMBOLA: 8 ANO ENSINO FUNDAMENTAL

\begin{tabular}{|l|l|}
\hline BIMESTRES & $\begin{array}{l}\text { CONTEÚDOS BÁSICOS - 80 ANO - } \\
\text { LEGISLAÇÃO AMBIENTAL }\end{array}$ \\
\hline $1^{\circ}$ BIMESTRE & $\begin{array}{l}\text { Licenciamento Ambiental; } \\
\text { (desmatamento e queimada } \\
\text { controlada) }\end{array}$ \\
\hline $2^{\circ}$ BIMESTRE & $\begin{array}{l}\text { Área de reserva legal; } \\
\text { Área de preservação permanente } \\
\text { (APP); }\end{array}$ \\
\hline $3^{0}$ BIMESTRE & $\begin{array}{l}\text { Legislação sobre a preservação dos } \\
\text { rios e nascentes; } \\
\text { Desenvolvimento de projetos sobre } \\
\text { recuperação de nascentes; }\end{array}$ \\
\hline $4^{\circ}$ BIMESTRE & $\begin{array}{l}\text { Legislação sobre o uso de } \\
\text { agrotóxicos; } \\
\text { Realização de projetos } \\
\text { interdisciplinares sobre questões } \\
\text { ambientais. }\end{array}$ \\
\hline
\end{tabular}

AGRICULTURA QUILOMBOLA: 9 ANO ENSINO FUNDAMENTAL

\begin{tabular}{|l|l|}
\hline BIMESTRES & $\begin{array}{l}\text { CONTEÚDOS BÁSICOS - 9 ANO - } \\
\text { ORGANIZAÇÕES SOCIAIS }\end{array}$ \\
\hline $1^{\circ}$ BIMESTRE & $\begin{array}{l}\text { Movimentos sociais quilombola; } \\
\text { Associações de agricultores } \\
\text { familiares e quilombolas; } \\
\\
\text { Sindicalismo; }\end{array}$ \\
\hline
\end{tabular}




\begin{tabular}{|l|l|}
\hline $2^{\circ}$ BIMESTRE & $\begin{array}{l}\text { Cooperativismo; } \\
\text { Movimentos de mulheres } \\
\text { quilombolas; }\end{array}$ \\
\hline $3^{\circ}$ BIMESTRE & $\begin{array}{l}\text { Movimento da agricultura familiar da } \\
\text { região; } \\
\text { Movimentos de jovens quilombolas; }\end{array}$ \\
\hline $4^{\circ}$ BIMESTRE & $\begin{array}{l}\text { Políticas públicas para a agricultura } \\
\text { familiar quilombola; } \\
\text { Economia Solidária. }\end{array}$ \\
\hline
\end{tabular}

AGRICULTURA QUILOMBOLA: 1 SÉRIE ENSINO MÉDIO

\begin{tabular}{|c|c|}
\hline BIMESTRES & $\begin{array}{l}\text { CONTEÚDOS BÁSICOS - 1ª SÉRIE } \\
\text { - PRODUÇÃO DA AGRICULTURA } \\
\text { QUILOMBOLA I }\end{array}$ \\
\hline $1^{\circ}$ BIMESTRE & $\begin{array}{l}\text { Criação de animais de pequeno porte } \\
\text { (galinha, pato, codorna, coelho e } \\
\text { outros); } \\
\text { Criação de peixes; } \\
\text { Métodos e prevenção e controle das } \\
\text { principais doenças que acometem os } \\
\text { pequenos animais; }\end{array}$ \\
\hline $2^{\circ}$ BIMESTRE & $\begin{array}{l}\text { Manejo e cuidados; } \\
\text { Alimentação; } \\
\text { Reprodução; }\end{array}$ \\
\hline 3을IMESTRE & $\begin{array}{l}\text { Comercialização de carnes e ovos; } \\
\text { Noções de Agroindústria para } \\
\text { pequenos animais; }\end{array}$ \\
\hline $4^{\circ}$ BIMESTRE & $\begin{array}{l}\text { Horticultura; } \\
\text { Jardinagem; } \\
\text { Atividades práticas. }\end{array}$ \\
\hline
\end{tabular}


AGRICULTURA QUILOMBOLA: 2ª SÉRIE ENSINO MÉDIO

\begin{tabular}{|c|c|}
\hline BIMESTRES & $\begin{array}{l}\text { CONTEÚDOS BÁSICOS - 2ª SÉRIE } \\
\text { - PRODUÇÃO DA AGRICULTURA } \\
\text { QUILOMBOLA II }\end{array}$ \\
\hline 1 BIMESTRE & $\begin{array}{l}\text { Criação de animais de médio porte } \\
\text { (suínos, ovinos, caprinos); } \\
\text { Métodos de prevenção e controle das } \\
\text { principais doenças que acometem os } \\
\text { animais de médio porte; }\end{array}$ \\
\hline $2^{\circ}$ BIMESTRE & $\begin{array}{l}\text { Manejo e cuidados; } \\
\text { Alimentação; }\end{array}$ \\
\hline 3 BIMESTRE & $\begin{array}{l}\text { Reprodução; } \\
\text { Comercialização de carnes e leite; }\end{array}$ \\
\hline 4을 BIMESTRE & $\begin{array}{l}\text { Noções de Agroindústria para } \\
\text { animais de médio porte; } \\
\text { Cultura da melancia, da abóbora e } \\
\text { outros de acordo com a realidade de } \\
\text { cada região; } \\
\text { Atividades práticas. }\end{array}$ \\
\hline
\end{tabular}

AGRICULTURA QUILOMBOLA - 3a SÉRIE ENSINO MÉDIO

\begin{tabular}{|c|c|}
\hline BIMESTRES & $\begin{array}{l}\text { CONTEÚDOS BÁSICOS - 3ª SÉRIE } \\
\text { - PRODUÇÃO DA AGRICULTURA } \\
\text { QUILOMBOLA III }\end{array}$ \\
\hline $1^{\circ}$ BIMESTRE & $\begin{array}{l}\text { Criação de animais de grande porte } \\
\text { (bovinos, equinos, muares e outros); } \\
\text { Métodos de prevenção e controle das } \\
\text { principais doenças que acometem os } \\
\text { animais de grande porte; } \\
\text { Manejo e cuidados; }\end{array}$ \\
\hline $2^{\circ}$ BIMESTRE & Alimentação; \\
\hline
\end{tabular}




\begin{tabular}{|l|l|}
\hline $3^{\circ}$ BIMESTRE & $\begin{array}{l}\text { Reprodução; } \\
\text { Comercialização de carnes e leite; }\end{array}$ \\
& $\begin{array}{l}\text { Noções de Agroindústria para } \\
\text { animais de grande porte; } \\
\text { Cultura do arroz; } \\
\text { Cultura do feijão; } \\
\text { Cultura do milho; }\end{array}$ \\
& $\begin{array}{l}\text { Cultura da mandioca; } \\
\text { Outras culturas de acordo com a } \\
\text { Bealidade de cada região; } \\
\text { Sementes crioulas; } \\
\text { Atividades práticas; (as atividades } \\
\text { práticas poderão ser executadas de } \\
\text { acordo com o planejamento do } \\
\text { professor e da escola). }\end{array}$ \\
\hline
\end{tabular}

